\title{
The Pliocene flora of Frankfurt am Main, Germany: taxonomy, palaeoenvironments and biogeographic affinities
}

\author{
Zlatko Kvaček $^{1}$ (D) $\cdot$ Vasilis Teodoridis $^{2}$ (D) Thomas Denk ${ }^{3}$ (D)
}

Received: 9 October 2018 / Revised: 30 January 2019 / Accepted: 2 May 2019 / Published online: 13 November 2019

(C) The Author(s) 2020

\begin{abstract}
The Pliocene flora of Frankfurt am Main described by Karl Mädler during the first half of the twentieth century is a key flora for the European Pliocene. In the present study, we revised the leaf fossil taxa described by Mädler and investigated plant material collected after Mädler's publication. The revised and augmented floral list comprises seven new species and some new combinations of taxa described by Mädler. In total, 16 gymnosperm species in 15 genera and 73 angiosperm species (of which 15 could not be assigned to a genus) in 40 genera are recognised in the leaf record. Main characteristics of the flora are the high diversity of conifers, the diverse assemblage of exclusively deciduous Fagaceae, including six species of oaks, and the high diversity of Rosaceae. These features indicate cool temperate climatic conditions (comparable to Lugano in southern Switzerland). Angiosperm genera that are today confined to North America and/or East Asia (Eucommia, Magnolia and Sassafras) also are deciduous, whereas evergreen taxa are shrubs typical of the understorey (Buxus, Ilex, Pachysandra, Prunus lusitanica type) and Viscum. Eighteen taxa recorded in the Pliocene of Frankfurt am Main are today absent from western Eurasia and eastern North America, and 25 taxa are absent from western North America. This shows $(i)$ a strong biogeographic link of the Pliocene flora of Frankfurt am Main with East Asia, (ii) surprisingly high levels of speciation (Pliocene endemisms) and (iii) that the European flora was more diverse in woody species shortly before the onset of major Pleistocene glaciations than today.
\end{abstract}

Keywords Flora $\cdot$ Relict taxa $\cdot$ Speciation $\cdot$ Biogeography $\cdot$ Pliocene $\cdot$ Europe

\section{Introduction}

Global cooling after the warm and mild phases of the Miocene (Zachos et al. 2001) led to a modernisation of north temperate

Electronic supplementary material The online version of this article (https://doi.org/10.1007/s12549-019-00391-6) contains supplementary material, which is available to authorized users.

Thomas Denk

Thomas.Denk@nrm.se

Zlatko Kvaček

zlatko.kvacek@gmail.com

1 Institute of Geology and Palaeontology, Faculty of Sciences, Charles University, Albertov 6, 12843 Prague 2, Czech Republic

2 Department of Biology and Environmental Studies, Faculty of Education, Charles University, Magdalény Rettigové 4, 11639 Prague 1, Czech Republic

3 Department of Palaeobiology, Swedish Museum of Natural History, Box 50007, 10405 Stockholm, Sweden floras (Mai 1995). The early part of the Pliocene (5.3-3.6 Ma) was characterised by warm conditions (ca. $3^{\circ} \mathrm{C}$ higher global surface temperatures) and higher sea levels (10-20 m; Ravelo et al. 2004) and slightly higher $\mathrm{CO}_{2}$ concentrations (Beerling and Royer 2011). During the second part of the Pliocene, gradual cooling culminated in a significant intensification of northern hemispheric glaciation at ca. $2.75 \mathrm{Ma}$ (Ravelo et al. 2004). Despite this, many exotic taxa persisted as relicts from older epochs (Mai 1995; Martinetto 2001), and modern diversity patterns of woody species (trees and shrubs) across the Northern Hemisphere were established only during and after the major Pleistocene glaciations (Magri et al. 2017). Today, species of the north temperate forest flora are distributed among western Eurasia, East Asia, western North America and eastern North America, approximately in the ratio 2:12:1:4 (Latham and Ricklefs 1993). These figures illustrate the strongly impoverished postglacial flora of Europe.

The Pliocene flora of Frankfurt am Main, Hessen, Germany (hereafter Frankfurt/M., Fig. 1), is a key flora for the European Pliocene. This flora has been repeatedly described (e.g. Geyler 


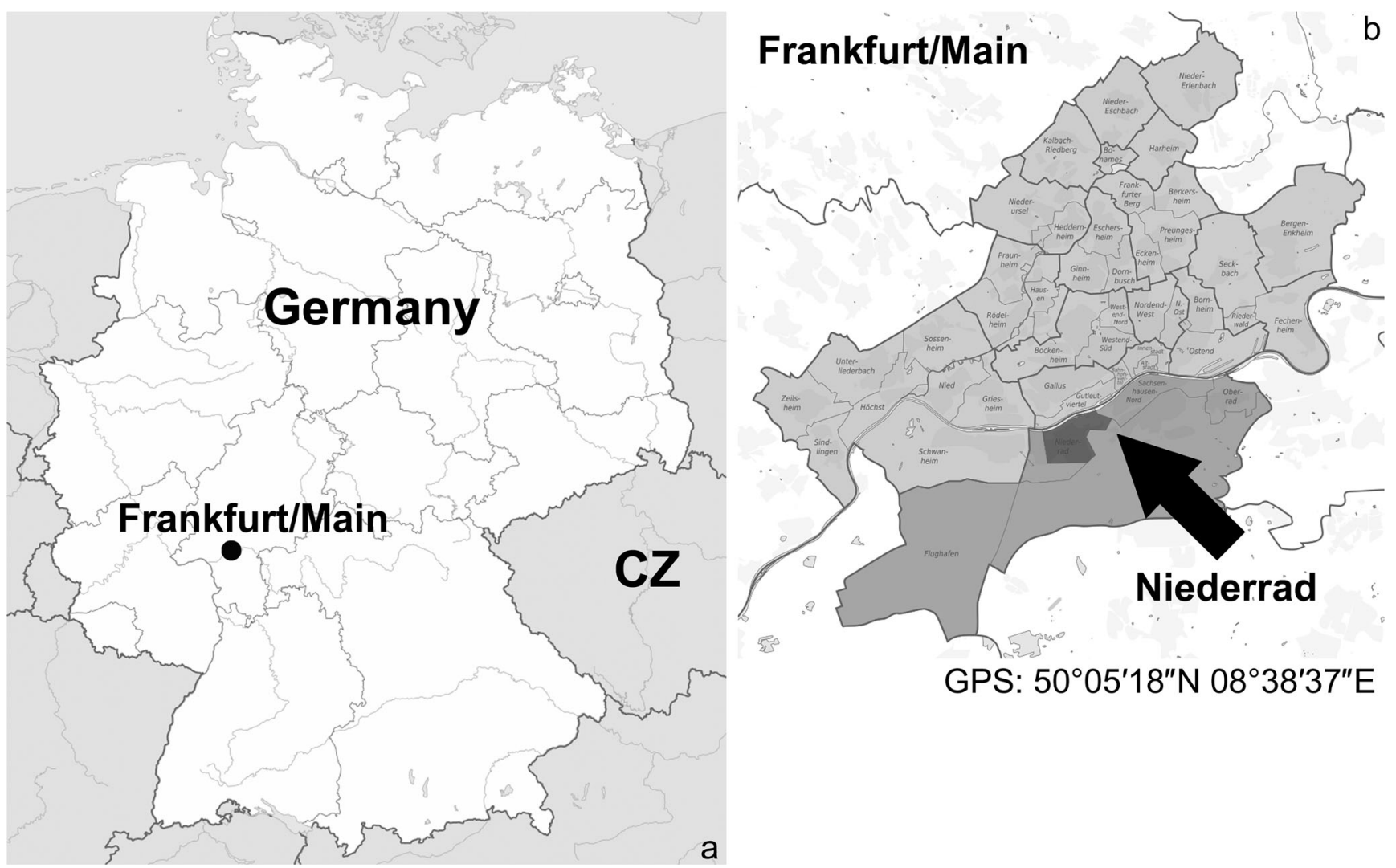

Fig. 1 Location of the studied flora of Frankfurt/Main (a) and position of the "Klärbecken Flora" site in Niederrad within Frankfurt/M. (b)

and Kinkelin 1887; Engelhardt and Kinkelin 1908; Mädler 1939) and is one of the richest macrofloras in the European Pliocene (Mai 1995). After Mädler's monograph, the Frankfurt "Klärbecken Flora" has never been revised.

After a previous revision of the Pliocene leaf flora of Auenheim, France (Kvaček et al. 2008), the main objectives of the present study were to re-assess previously published leaf morphotypes and to describe unpublished plant material of the Pliocene "Klärbecken Flora" site in Niederrad, Frankfurt/M. A major problem for the revision of this flora was that most of the material gathered since 1885 and housed at the Senckenberg Research Institute and Natural History Museum Frankfurt as a unique "glass herbarium" (Kräusel 1940) was destroyed in 1945 during World War II (Schaarschmidt 1980). Therefore, our objectives were (i) to investigate duplicate material, which could serve as a basis for the re-assessment of the Pliocene flora of Frankfurt (Mädler 1939), and (ii) to describe additional unpublished material recovered after World War II (Schaarschmidt 1980). Duplicates and unpublished material are housed in the collections of the Senckenberg Research Institute and Natural History Museum Frankfurt, Swedish Museum of Natural History, Stockholm and British Museum of Natural History, London Natural Science museum. Only leaf fossils are dealt with in this review, while the wood and palaeocarpological records (Supplementary material File 1) are left aside for future studies. The revised plant material was then used to assess biogeographic relationships of the flora of Frankfurt and to evaluate speciation events in the Pliocene. Finally, some conclusions regarding palaeoenvironments and palaeoclimate are presented.

\section{Material and methods}

Duplicate material and unpublished material of the Pliocene flora of Frankfurt

When studying the collections at the Senckenberg Research Institute and Natural History Museum Frankfurt, one of us (Z.K.) noticed a sheet of paper with a list of material sent to the "Naturhistorisches Reichsmuseum Stockholm", written by an anonymous keeper and without an author and date with a mechanical typewriter and containing out-of-date taxonomy (e.g. Planera ungeri). This short text lists Ginkgo adiantoides (leaf fragments), Abies pectinata (one seed cone), Picea latisquamosa (seed cone), Pinus montana fossilis (one seed cone), Pinus timleri (seed cone scale), Acer sp. (fruits), Betula (fruit bracts), Buxus sempervirens (leaves and fruit cupules), Carpinus grandis (leaf, involucre fragment), Carya alba fossilis (fruits), Carya ovata (fruits), Corylus avellana (fruits), Fagus pliocaenica (leaves), Ilex aquifolium (leaf remains), Juglans cinerea fossilis (fruits), Liquidambar pliocaenicum (infructescences), Planera 
ungeri (leaves) and Quercus (one leaf fragment). Additional notes on this sheet are written by hand and dispatched on the 19th February 1939 with a note that particularly conifer material would be welcome. Additions include Torreya nucifera fossilis (one fragmentary needle and epidermal preparation), Podocarpus kinkelinii (three leaves in one preparation), Abies pectinata fossilis (needle), Abies sclereidea (two needle fragments), Sequoia langsdorfii (three preparations), Taxodium distichum fossilis (one preparation), Libocedrus pliozänica (one twig), Carya globosa (one stone), Viscophyllum pliozänicum (leaf and epidermal preparation), Styrax obovatum (two stones), Stuartia europaea (one fruitlet) and Buxus sempervirens fossilis (one epidermal preparation). Further, material of Pinus timleri (two seeds), Viscophyllum miquelii (one leaf and one epidermal preparation) and Ilex aquifolium fossilis (one leaf and an epidermal preparation) was also sent to Stockholm. Hence, for the present re-assessment, we also concentrated on the material stored at the Stockholm museum (see Supplementary material File 1 for carpological material housed at the Stockholm museum).

Duplicates of the original or additional specimens from the Pliocene flora of Frankfurt/M. are likely to be found in more institutions. We have seen additional material at the British Museum of Natural History, London, distributed by Richard Kräusel. Such glass preparations and slabs with macrofossils are the only remnants of the once very rich collections of the Pliocene plant assemblage of Frankfurt that had been assembled since 1884 and were mainly known as "glass herbarium" (Kräusel 1939).

Five papers dealing with material from the Pliocene of Frankfurt, namely on leaves of Fagus (Kvaček and Walther 1991; Denk 2004), seed cones of Pinus timleri (Kvaček et al. 2014a, b), Pseudotsuga loehrii (Kunzmann 2014), and leaves of Ginkgo (Denk and Velitzelos 2002) have been published after the classical paper by Mädler (1939); they are considered in the systematic part.

\section{Preparation of the fossil material}

The preparations of leaf fossils that formed the basis of the previous studies of the Pliocene flora of Frankfurt/M. followed a protocol described in Mädler (1939, p. 6). The sandy layers included "leaf beds", which allowed, after soaking in water and $\mathrm{KOH}$, a mechanical separation of leaf fossils. The first extensive work of preparing slide preparations of fossil leaves was done by F. Kinkelin (Mädler 1939). The mummified leaf fossils were embedded between glass frames of the same size in glycerol and sealed with an unknown material. This procedure turned out to be less successful because glycerol evaporated through the framing. Later, Mädler attempted to improve the collection by spreading leaf fossils on glass, embedded in glycerol jelly and covered by a smaller plastic sheet, then sealed with Canada balsam (Mädler 1939, pp. 5-6).
Unfortunately, most of these glass preparations were destroyed as mentioned above. The procedure developed by Mädler was also employed for preparations of the newly excavated material obtained by Richard Kräusel who transferred it for further preparation work to Wolfgang Haas in 1956 (see personal letter by Kräusel to Haas in the archive of the Department of Palaeobotany of the Senckenberg Museum; Volker Wilde, personal communication 2014). These specimens are quite well preserved and used in the present study. Only in rare cases the embedding material (glycerol jelly) partly dried out.

The collection of new preparations is now housed in the Section of Palaeobotany, Senckenberg Research Institute and Natural History Museum Frankfurt. It is arranged systematically according to the fossil species. The inventory numbers (SF.B numbers) follow this systematic arrangement. The numbers were scratched onto the glass slides by an anonymous keeper.

For the present study, only a small part of the glass preparations of macrofossils has been re-opened to get leaf lamina fragments for cuticle preparations. Mädler (1939) used Schulze solution in combination with ammonia for maceration and a similar method was employed for the present study except for using 5\% KOH instead of ammonia (see protocol in Kvaček et al. 2008). The preparation of cuticles was not always successful, namely in case of delicate cuticles of deciduous foliage when highly diluted Schulze reagent was used for maceration. Although not attempted here, fluorescence microscopy may turn out to be promising in future research.

The newly revised specimens and epidermal slides are housed in the collection of the Senckenberg Research Institute and Natural History Museum Frankfurt (numbers with prefix SF.B). Some specimens of the original material available for this study are housed at the Swedish Museum of Natural History, Stockholm (numbers starting with $S$ ) and the British Museum of Natural History, London (specimens numbered with prefix $\mathrm{V}$ ).

Inferring palaeoclimate and palaeoenvironments

Palaeoclimate and palaeoenvironment estimates were made using Climate Leaf Analysis Multivariate Program (CLAMP) and Integrated Plant Record (IPR) vegetation analysis. The CLAMP method (e.g. Wolfe and Spicer 1999) uses physiognomic characteristics of the studied plant assemblage of Frankfurt/Main presented in Supplementary material File 2 and the physiognomic and gridded meteorological calibration datasets from 144 sites "Physg3br/GRIDMet3br" (see Spicer et al. 2009) selected by the statistical tool published by Teodoridis et al. (2012). The CLAMP analysis was performed using a web application designed by Yang et al. (2011), which is free to access at the official CLAMP website (Spicer 20112019; for details, see Supplementary material File 2).

The IPR-vegetation analysis is a semi-quantitative method (Kovar-Eder et al. 2008) to evaluate zonal vegetation. This 
method scores key component groups (functional types) of the integrated plant fossil record. This technique has been verified using modern plant assemblages from SE China and Japan (Teodoridis et al. 2011) and has recently been tested by the second author using living European and Caucasian plant assemblages (Bohn et al. 2004).

\section{Systematic palaeobotany}

The leaf taxa listed below were partly described by Karl Mädler in his original study (Mädler 1939) and were dealt with by various authors in subsequent studies (mentioned in the synonymies). Several novelties for the Pliocene flora of Frankfurt/M. have been provisionally indicated in the collections (possibly by R. Kräusel); other undescribed taxa are here suggested for the first time. Only a few separate papers have appeared recently, which are related to the Pliocene flora of Frankfurt/M. (e.g. Kvaček and Walther 1991; Denk 2004), partly based on the material from other sites (e.g. Pinus timleri by Kvaček et al. 2014a, b; Ilex geissertii by Kvaček et al. 2008). We prefer to assign the fossils to fossil-species instead of using names of modern taxa followed by "fossilis" as Mädler (1939) did. This usage is still maintained in current papers dealing with Pliocene taxa (e.g. Geissert 1973; Mai and Walther 1988; Hably and Kvaček 1997; Knobloch 1998). In a few cases, when leaf morphology and cuticle structure are virtually identical with modern species, e.g. Acer platanoides, we called the fossiltaxon Acer aff. platanoides, indicating that the fossil most likely represents the lineage leading to the modern species, but perhaps not the species itself.

The arrangement of taxa follows the system based on the classification suggested by the Angiosperm Phylogeny Group (APG IV 2016). The collections studied include also fossils of reproductive organs (seed cones, winged carpological material), which are briefly mentioned in the systematic section but not treated in detail. Only selected foliage specimens of the entire collection are listed and illustrated, mainly those studied by epidermal anatomy. Descriptions are only provided for taxa that have not been described by Mädler (1939).

\section{Gymnosperms \\ Ginkgoaceae Engler \\ Ginkgo Linnaeus}

Ginkgo adiantoides (Unger) Heer

Fig. 2a-c

1939 Ginkgo adiantoides (Unger) Heer; Mädler, p. 46, pl. 5, figs. $1-4$
Fig. 2 a Ginkgo adiantoides (Unger) Heer, leaf, SF.B 11495a, 10 mm. b Ginkgo adiantoides (Unger) Heer, leaf, SF.B 11495b, 10 mm. c Ginkgo adiantoides (Unger) Heer, leaf, SF.B 11493, $10 \mathrm{~mm}$. d Calocedrus pliocaenica (Kinkelin) Kvaček, Teodoridis et Denk comb. nov., needle leaf, neotype S082691, 10 mm. e Glyptostrobus europaeus (Brongniart) Unger, leafy shoot, V 17167, $10 \mathrm{~mm}$. f Sequoia abietina (Brongniart) Erw. Knobloch, leafy shoot, SF.B 11707, $10 \mathrm{~mm}$. g Sequoia abietina (Brongniart) Erw. Knobloch, leafy shoot, S.P9101434, $10 \mathrm{~mm} . \mathbf{h}$ Taxodium dubium (Sternberg) Heer, leafy shoot, SF.B 11431a, $10 \mathrm{~mm}$. i Taxodium dubium (Sternberg) Heer, leafy shoot, SF.B 11470, 10 mm. j Taxodium dubium (Sternberg) Heer, leafy shoot, SF.B 11431b, $10 \mathrm{~mm}$. k Taxodium dubium (Sternberg) Heer, leafy shoot, SF.B 11431c, $10 \mathrm{~mm} . \mathbf{I}$ Abies sp., needles with enlarged bases, SF.B 11440, 10 mm. m Pinus sp., needles in double fascicle, SF.B 11430, $10 \mathrm{~mm}$. n Pseudotsuga kinkelinii (Mädler) Kvaček, Teodoridis et Denk comb. nov., needle leaf, SF.B 11718, 10 mm. o Pseudotsuga kinkelinii (Mädler) Kvaček, Teodoridis et Denk comb. nov., needle leaf, SF.B 11419, $10 \mathrm{~mm}$. p Pseudotsuga kinkelinii (Mädler) Kvaček, Teodoridis et Denk comb. nov., needle leaves, lectotype V.17169, 2 mm. q Pseudotsuga kinkelinii (Mädler) Kvaček, Teodoridis et Denk comb. nov., needle leaves, epitype SF.B $11420 \mathrm{~b}, 2 \mathrm{~mm}$. r Torreya aff. nucifera Siebold et Zuccarini, needle leaf, $\mathrm{V} 17176,10 \mathrm{~mm}$

Material: Eighteen leaves at Frankfurt/M., one in LOndon, V.17168, three at Stockholm, S142884, S116317-01, S116317-02, S116314 (glass preparations).

Description: See Mädler (1939, pp. 46-47).

Remarks: No additional information to that published by Mädler (1939) has been obtained by the study of the newly collected material. The description corresponds to the previously published data in Mädler (1939). For comments on the taxonomy, see Kvaček et al. (2008). The material from the new collection was used for a study of stomatal density as a proxy for atmospheric $\mathrm{CO}_{2}$ concentration (Retallack 2001). Denk and Velitzelos (2002) noted that the abaxial epidermis of Ginkgo from Frankfurt shows only faint papillae, while in late Miocene material from northern Greece, the papillae were prominent and overarching the stomata.

Cupressaceae

Calocedrus Kurz

Calocedrus pliocaenica (Kinkelin) Kvaček, Teodoridis et Denk comb. nov.

Fig. 2d

1908 Libocedrus pliocaenica Kinkelin in Engelhardt and Kinkelin, p. 191, pl. 23, figs. 4, 5f (basionym)

1908 Callitris brongniartii sensu Kinkelin in Engelhardt and Kinkelin, p. 190, pl. 23, figs. 4, 5, pl. 23, fig. 5a-e

1908 Algacites caulerpoides Engelhardt and Kinkelin, p. 187, pl. 22 , fig. 32

1939 Libocedrus pliocaenica Kinkelin; Mädler, p. 42, pl. 4, figs. 1-6, text-figs. 12-14

1961 Heyderia pliocaenica (Kinkelin) Szafer, p. 28, pl. 7, figs. 9-12, pl. 8, figs. 1-7 


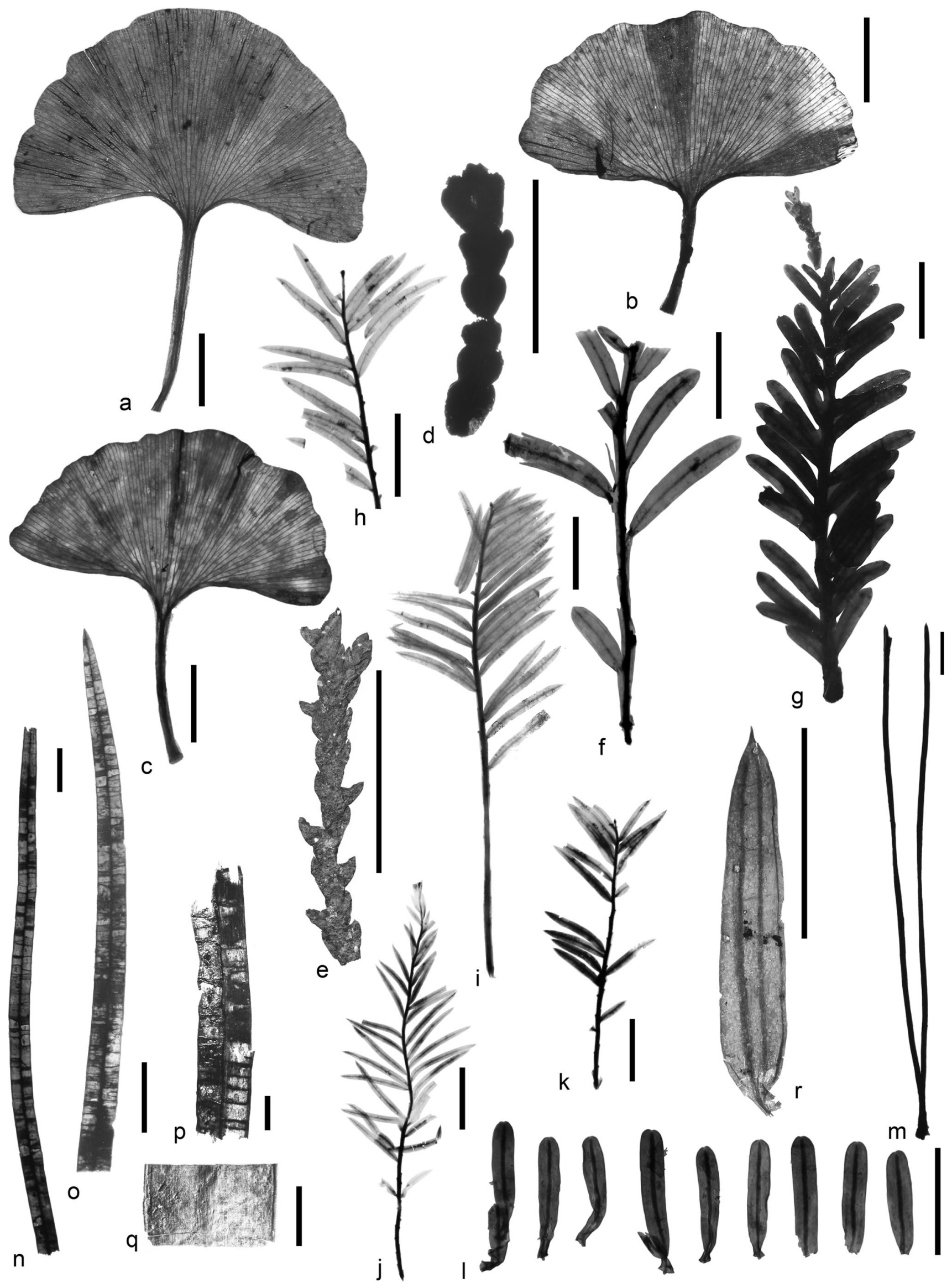


Material: No syntype at SF (the originally selected lectotype by Mädler 1939 was a seed figured in Engelhardt and Kinkelin 1908, pl. 23, fig. 4), only one slide with a twig available at Stockholm (S082691).

Neotype selected here: S082691 (fig. 2d)_foliage shoot (a duplicate from the material treated by Mädler 1939).

Description of the neotype: Isolated foliage shoot, $15 \mathrm{~mm}$ long, up to $3.8 \mathrm{~mm}$ wide, shoot composed of six pseudowhorls with rounded to widely cuneate base and obtuse apices of two marginal and two facial leaves.

Remarks: Mädler (1939) provided a detailed description of the original material destroyed during the war, which is sufficient for the identification of this rare conifer. Szafer (1961) included it into the genus Heyderia K. Koch, a younger synonym of Calocedrus Kurz.

Cryptomeria D. Don

Cryptomeria rhenana Kilpper

Fig. $15 \mathrm{a}-\mathrm{c}$

1953 Cryptomeria sp.; Sveshnikova 1953, p. 117, text-figs. 3.1, 3-4

1958 Cryptomeria japonica D. Don fossilis Sveshnikova; Kolakovskii, p. 322, pl. 3, fig. 1

1963 Cryptomeria japonica D. Don fossilis Sveshnikova, p. 225 , pl. 12, figs. 9-10

1968 Cryptomeria rhenana Kilpper, p. 104, pl. 34, figs. 2330 , pl. 35 , figs. $1-8$, pl. 38 , figs. $3-4$

Material: Cuticle preparations S117681, 117682.

Description: Stomata rounded cyclocytic, subsidiary cells four to six, large, similar in form and size, stomatal complexes irregularly orientated.

Remarks: First, Sveshnikova $(1953,1963)$ described more complete twigs with this type of epidermal structure from the late Neogene sites of Georgia (Chokhati, Duab) and compared it with the living Cryptomeria japonica living in Japan and China. Complete fertile shoots from upper Miocene deposits of Rhineland including cuticle structure were investigated in detail by Kilpper (1968). Cuticle structure of the latter is the same as in the material of Frankfurt/M. (SF).

Glyptostrobus Endlicher

Glyptostrobus europaeus (Brongniart) Unger

Figs. $2 \mathrm{e}$ and $15 \mathrm{j}-1$

1968 Glyptostrobus europaeus (Brongniart) Unger; Kilpper, p. 104 , pl. 37 , fig. 5

Material: Two fragmentary twigs V.17167 pro parte (assigned to Callitris brongniartii Saporta), cuticle preparations S 118207-118213.
Description: Twigs with helically disposed scale leaves, partly flat, not anatomically studied. Cuticle preparations showing macerated amphistomatic leaves, on abaxial cuticle ordinary cells with straight anticlines, 20-50 $\mu \mathrm{m}$ long and 7-20 $\mu \mathrm{m}$ wide, showing distinct crystal cavities, stomata cyclocytic, subsidiary cells in two to three circles, four to six cells per circle, the inner circle thick-walled, stomatal crypts irregularly orientated, two adjacent stomatal complexes usually sharing subsidiary cells.

Remarks: The twigs were identified as Callitris brongniartii Saporta obviously by Kinkelin. Two specimens correspond to sterile foliage recovered at the type locality of Alonissos (Iliodroma) Island (Mantzouka et al. 2019). The third may belong likely to Sequoia abietina (see below). The cuticles prepared by Florin in Stockholm correspond to the structure obtained from fertile twigs of Glyptrostrobus europaeus from late Miocene deposits of Rhineland (Kilpper 1968, p. 104, pl. 37, fig. 5). It differs from that of Taiwania Hayata by stomata usually sharing subsidiary cells (Sveshnikova 1963, p. 212) and from Sequoia and Sequoiadendron by shorter ordinary cells in non-stomatal areas (Sveshnikova 1963, p. 212).

Several fossil species of Glyptrostrobus were distinguished (e.g. Dorofeev 1974, Mai in Mai and Walther 1988) based on fossil seeds. These have not been recovered in the Pliocene deposits at Frankfurt/M.

Sequoia Endlicher

Sequoia abietina (Brongniart) Erw. Knobloch

Figs. $2 \mathrm{f}$, $g$ and $15 \mathrm{i}$

1908 Sequoia langsdorfii (Brongniart) Heer sp. pliocaenicasensu Kinkelin in Engelhardt and Kinkelin, p. 199, 278, pl. 24, figs. 1, 3-4

1908 Taxodium distichum Richard pliocaenicum sensu Kinkelin in Engelhardt and Kinkelin, p. 199, pro parte, pl. 23, fig. 21c

1908 Pteris sp. sensu Kinkelin in Engelhardt and Kinkelin, p. 187, pl. 22, fig. 31

1908 Rhamnus cathartica Linnaeus fossilis sensu Engelhardt and Kinkelin, p. 264, pl. 32, fig. 32, fig. 30

1939 Sequoia langsdorfii (Brongniart) Heer sensu Mädler, p. 37, pl. 1, figs. 38-39, pl. 3, figs. 8-9

Material: One fragmentary twig V.17167 pro parte (assigned to Callitris brongniartii), newly recovered material SF.B 11408 (?), 11410 (two shoots), 11411, 11415, 11432, 11461, 11472, 11474 (four shoots), 11475 (four shoots), 11476 (three shoots), S.P9101434 (one shoot), one shoot (S082692) and several cuticle preparations S118123-118130 from Stockholm.

Description: See Mädler (1939, pp. 37-39).

Remarks: Leafy shoots embedded in glass preparations correspond in morphological features to those of modern Sequoia sempervirens (D. Don) Endlicher and fossil S. abietina type. 
They were recorded from various plant assemblages of the European Neogene (e.g. Knobloch 1964; Kvaček 1976). The cuticle structure observed in the Stockholm specimens corresponds to fossils assigned to Sequoia langsdorfii (Brongniart) Heer by Kilpper (1968), pl. 38, figs. 5-7) from late Miocene deposits of Rhineland, and to other fossil records of the Sequoia abietina type in Europe.

Taxodium Richard

Taxodium dubium (Sternberg) Heer

Fig. $2 \mathrm{~h}-\mathrm{k}$

1887 Taxodium distichum Richard pliocaenicum Geyler et Kinkelin, p. 11, pl. 1, fig. 2

1908 Taxodium distichum Richard pliocaenicum Geyler et Kinkelin; Engelhardt and Kinkelin, p. 198, 278, pl. 23, figs. 21a-b, d-h, fig. 30

1939 Taxodium distichum Richard fossilis; Mädler, p. 39, pl. 4 , fig. 7

Material: Only newly recovered material - leafy shootsSF.B 11406 (three shoots), (?) 11407, 11409, 11412, 11413, 11424, 11425 (two shoots), 11426, (three shoots), 11427 (three shoots), 11428 (four shoots), 11429, 11430 (three shoots), 11431 (three shoots), 1437 (two shoots), 11441 (two shoots), 11442, 11443, 11444, 11445, 11446, 11447, 11448, 11449 (six shoots), 11450, 11451, 11452, 11453, 11454 (five shoots), 11455, 11456, 11457, 11458 (two shoots), 11459, 11460, 11462, 11463 (two shoots), 11464 (two shoots), 11465 (four shoots), 11466, 11467 (two shoots), 11468, $11469,11470,11471,11472,11474$ (four shoots), 11475 (four shoots), 11476 (three shoots), one slide in Stockholm.

Description: See Mädler (1939, pp. 39-41).

Remarks: Leafy shoots embedded in glass preparations correspond in morphological features to the type material from the Bohemian Miocene (see Kvaček 1976). Macerations of needles have not been successful, and the obtained preparations reveal only sub-macerated abaxial stomata orientated perpendicularly or obliquely to the needle length. Mädler (1939) came to similar results when attempting cuticle macerations of his material. For a detailed discussion, see Kunzmann et al. (2009).

\section{Pinaceae}

Besides Pinus, also seed cones and seeds assigned to Picea latisquamosa (Ludwig) Geyler et Kinkelin, Picea sp., Larix europaea Lamarck et DC. fossilis Geyler et Kinkelin, Keteleeria loehri (Geyer et Kinkelin) Kinkelin and Pseudolarix kaempferi (Lamber) Gordon fossilis Florschütz were included in the Pliocene flora of Frankfurt/M. by Mädler (1939). These records are not treated in the systematic part below. For the seed cones of Pinus, the revisions by Mai
(1986) and Kvaček et al. (2014a), b) and for Keteleeria loehri (Geyler et Kinkelin) Kinkelin, the revision by Kunzmann (2014) are accepted.

Abies Miller

Abies sp.

Fig. 21

1908 Abies sp.; Engelhardt and Kinkelin, p. 220, pl. 27, figs. 4-5 (needles), p. 219, pl. 36, fig. 13 (seed)

1939 Abies pectinata DC. fossilis Mädler, p. 19, pl. 1, figs. $10-17$, pl. 3 , figs. $6-7$, text-figs. $5,8,10$

Material: SF.B 11440 (one slide containing nine needles), a needle in Stockholm (S082695) of the material quoted by Mädler (1939), one slide at V. 26362, otherwise missing.

Description: See Mädler (1939, pp. 19-21).

Remarks: Material embedded in glass preparations does not allow studying anatomical structure, but the overall morphology, particularly the enlarged needle bases, is diagnostic of needles of fir. Detailed descriptions of needle anatomy by Mädler (1939) also corroborate this generic assignment. According to Mädler (1939, p. 21), these needle leaves differ from the Pliocene Abies albula (Ludwig) Müller-Stoll from the locality Dernbach by morphology (rounded or emarginate tips).

Picea A. Dietrich

Picea omoricoides C.A. Weber

Fig. $15 \mathrm{~d}-\mathrm{f}$

1898 Picea omoricoides C.A. Weber, p. 5, pls. 11-13

Material: One slide V. 17164 identified as Picea, cuticle preparations S117938-117942 coll. Stockholm.

Description: Macerated needles up to $2 \mathrm{~mm}$ wide, incomplete in length, rounded at apex, one side without stomata, ordinary cells coarsely undulate, ca. $15 \mu \mathrm{m}$ wide, hypodermal cells straight-walled, similar in size, opposite side with longitudinally arranged narrow epidermal cells with deeply and regularly undulate anticlinal walls, stomata in five to eight rows, longitudinally aligned, bicyclic, subsidiary cells four to eight, with shallow undulate to pitted anticlinal walls, polar quadrangular, usually bordering two adjacent stomata, lateral subsidiary cells elongate, on one side usually shared among two adjacent stomata.

Remarks: The epidermal topography corresponds to that described for the Pliocene records of Picea omoricoides from Germany (Gerstungen and other sites, Mai and Walther 1988) and North Bohemia (Cheb Basin, Vildštejn Formation, Bůžek et al. 1985; Teodoridis et al. 2017).

Pinus Linnaeus

Pinus sp.

Fig. $2 \mathrm{~m}$ 
1908 Stiel von Acer, Engelhardt and Kinkelin, p. 296, pl. 34, fig. $11 \mathrm{~b}$

1939 Kurztriebe von Pinus; Mädler, p. 35, pl. 1, fig. 36

Material: SF.B 11433 and 11436 (two 2-needled fascicles), two missing specimens of 2- and 3-needled fascicles quoted by Mädler (1939).

Description: See Mädler (1939, p. 35).

Remarks: Needles in double fascicles have not been anatomically studied being enclosed in glycerol jelly between glass and plastic plates. They may belong to some of the associated seed cones but a straight-forward connection cannot be established.

\section{Pseudotsuga Carrière}

Pseudotsuga kinkelinii (Mädler) Kvaček, Teodoridis et Denk comb. nov.

Figs. $2 \mathrm{n}-\mathrm{q}$ and $15 \mathrm{~m}-\mathrm{o}$

1939 Podocarpus kinkelinii Mädler, p. 14, pl. 1, figs. 2-3, pl. 2, figs. 4-5, text-figs. 2, 6 (basionym)

1988 Cephalotaxus multiserialis (Weyland) Mai et Walther, $\mathrm{p}$. 71, pl. 6, fig. 23, text-fig. 7

Material: Two slides V.17169 and S082700; new material of isolated needles includes specimens SF.B 11418-11420a-c (one needle complete-epitype), 11421, 11422, 11423a, b and several cuticle preparations of SF.B 11419.

Lectotype suggested here: V. 17169 (fig. 2p).

Epitype suggested here: SF.B 11420 b (fig. 2q).

Description: Leaves needle-like, up to $155 \mathrm{~mm}$ long, 3$4 \mathrm{~mm}$ wide, univeined, narrow cuneate at base, sessile, acute at apex, hypostomatic. Upper side consisting of thickly cutinised prosenchymatous epidermis composed of parallel aligned thick-walled cells. Lower side with a medial keel-like vein and two lateral zones bearing narrow papillate stomatal bands. Stomata monocyclic, longitudinally orientated, closely set in up to 13 rows, touching each other by lateral subsidiary cells, polar subsidiary cells partly shared by two adjacent stomata, rarely with additional cells, both bulging and thickly papillate. Ordinary cells outside the stomatal zones longitudinally aligned, similar to those of the adaxial epidermis.

Remarks: The stomatal topography as well as details of epidermal structure corresponds to the modern species of Pseudotsuga Carrière rather than to Cathaya Chun et Kuang. Mädler (1939) assigned these peculiar, long needles to Podocarpus L'Héritier ex. Persoon and mentioned great difficulties in investigating the epidermal parts. Also the presently studied material (SF.B 11419) was not easy for preparation of cuticles. The lower epidermis remained firmly attached to the leaf tissue in spite of strong maceration. Cathaya is fairly similar to the fossils discussed but lacks papillae within stomatal bands and has quadrangular polar subsidiary cells (Kunzmann 2014). Delicate deciduous needle foliage of Pseudolarix Gordon may recall Pseudotsuga kinkelinii but has stomatal zones smooth.

A long needle from the Pliocene of Auenheim corresponding also in the epidermal structure to the Frankfurt/M. specimens was misinterpreted as Cathaya (see Kvaček et al. 2008, p. 8, pl. 1, fig. 10, pl. 16, fig. 6, as Cathaya sp.). Szafer (1961), p. 26, pl. 7, figs. 1-6) referred needle fragments from the late Miocene of Poland with similar epidermal structure to Podocarpus. Foliage of Pseudotsuga kinkelinii co-occurs with seed cones recently investigated by Kunzmann (2014) and assigned to Pseudotsuga loehrii (Geyler et Kinkelin) L. Kunzmann.

By its acute leaf apex Pseudotsuga kinkelinii is similar to the extant North American species. However, most modern species have shorter needles. Pseudotsuga macrocarpa (Vasey) Mayr from southern California is most similar by seed cone morphology to $P$. loehrii (Kunzmann 2014) as well as to $P$. kinkelinii by needles up to $50 \mathrm{~mm}$ or even $60-80 \mathrm{~mm}$ long with acute tips. This modern species grows also in riparian habitats along with Acer macrophyllum Pursh and Populus trichocarpa Torrey et A. Gray (Barbour 1988).

Pseudotsuga sclereidea (Mädler) Kvaček, Teodoridis et Denk comb. nov.

Fig. 16a

1908 Abies sp.; Engelhardt and Kinkelin, p. 221, pl. 27, figs. 7-8 11 (pro parte)

1939 Abies sclereidea Mädler, p. 22, pl. 1, figs. 8-9, pl. 3, figs. 1-5, text-figs. 4, 11

Material: Two needle fragments of syntypes at Stockholm, no topotype material at SF.

Lectotype selected herein: S082707 (fig. 16a) coll. Mädler (1939).

Description: Needle fragments, the mesophyll tissue containing sclereids. For detailed description, see Mädler (1939), p. 22, pl. 1, figs. 8-9, pl. 3, figs. 1-5, text-figs. 4, 11).

Remarks: Although Mädler (1939) described in detail the epidermal structure of the needles, he included them within a new species of Abies being unaware that sclereids occur in needle tissue of several conifers. The stomatal topography clearly differs from Abies and indicates close affinity with Pseudotsuga. Fragmentary needles of the same kind were noted from the Pliocene of Auenheim and compared with the modern P. menziesii (Mirbel) Franco (Kvaček et al. 2008, p. 9 , pl. 1, figs. $14-15$, pl. 16, fig. 8).

Tsuga (Endlicher) Carrière

Tsuga (sect. Tsuga) sp. 
1939 Tsuga europaea Menzel; Mädler, p. 24, pl. 1, figs. 21-29

Material: No specimen at SF or NRM.

Remarks: Mädler (1939) described 15 needles, all of which were destroyed in 1945. The figured needles correspond to some Pliocene records in Europe (Krościenko-Szafer 1947, partly as T. caroliniana, Berga-Mai and Walther 1988, as Tsuga sp., Auenheim-Kvaček et al. 2008, as Tsuga (sect. Tsuga) sp.). Most other records of Tsuga are based on seed cones including that of T. europaea Menzel (Kunzmann and Mai 2005).

Sciadopityaceae Luerssen

Sciadopitys Siebold et Zuccarini

Sciadopitys tertiaria Menzel

Fig. 15g, h

1908 Abies sp.; Engelhardt and Kinkelin, p. 220, pl. 27, fig. 6 1922a Sciadopitys tertiaria Menzel; Florin, p. 3, pl. 1, figs. 1-4 1922b Sciadopitys tertiaria Menzel; Florin, p. 263, figs. 2c-e 1939 Sciadopitys tertiaria Menzel; Mädler, p. 36

Material: Two slides, S118040, 118054.

Description: See Florin (1922a, b).

Remarks: The material at hand was recovered in collections of the previous working place of Rudolf Florin at Stockholm and represents originals to the paper mentioned above. According to Weyland et al. (1967), Pliocene and living differ from Miocene Sciadopitys in the lack of the papillate margin of the stomatal zone, which is distinctly papillate in the Miocene material. However, the studied samples from the Pliocene of Frankfurt do show narrow papillate rows along the stomatal zone, probably not noted by Florin. Hence, the argument to establish a Miocene species $S$. marcodurensis Weyland et al. is not valid.

Taxaceae Gray

Taxus Linnaeus

Taxus aff. baccata Linnaeus

Fig. 16b, c

Material: One slide, S082704.

Description: Needle fragments, $2-2.5 \mathrm{~mm}$ wide, incomplete in length, tip shortly pointed, leaves hypostomatic, adaxial cuticle smooth, anticlinal walls straight to slightly bent, outlines of unspecialised cells isodiametric to slightly elongate polygonal, in sub-parallel rows, $25-50 \mu \mathrm{m}$ in diameter, abaxial cuticle thick, two longitudinal stomatal bands consisting of five stomatal rows, completely covered by papillae, stomata longitudinally orientated, amphicyclic, with strong Florin rings, widely disposed and not sharing subsidiary cells, guard cell pairs deeply sunken, surrounded by four to six subsidiary cells, medial and both lateral non-stomatal zones partly smooth, partly papillate halfway towards stomatal bands, unspecialised cells straight-walled, quadrangular elongate, $40-120 \mu \mathrm{m}$ long and 20-30 $\mu \mathrm{m}$ wide, anticlinal walls straight to slightly curved, smooth.

Remarks: The single microscopic slide available was identified as Taxus francofurtana Florin on the label with a note “orig. Florin, pl. 8, fig. 19, pl. 9, figs. 9-12". Florin probably intended this material to be included in a more extensive revision on fossil Cephalotaxus and Taxus (see Seward and Edwards in Boulter and Kvaček 1989, p. 62), but this revision remained unpublished. According to its epidermal structure, the specimen differs from T. inopinata Givulescu (1973, 1975) from the Romanian Pannonian and from Taxus sp. 2 sensu Kvaček (1984) from the Pliocene of North Bohemia because the abaxial papillate zones along the stomatal bands are wider, reaching halfway to the stomatal bands. In the Romanian material, papillae are confined to the stomatal areas and also in the fragment from the Bohemian Pliocene/ Pleistocene described as Taxus sp. 2 sensu Kvaček 1984), papillae densely covering the stomatal bands are almost lacking on adjacent non-stomatal zones (Kvaček 1984, fig. 4a, e). The Pliocene record of Taxus from Willershausen, identified as Taxus baccata L. fossilis (Straus 1952, p. 20, pl. 4, figs. 67, pl. 7, figs. 28, 30) does not differ from that of Frankfurt according to the epidermal anatomy and may belong to the same fossil species. We follow Macovei (2013), who recommended not using independent fossil species names for remains that represent close ancestors of Taxus baccata $\mathrm{L}$. The Oligocene T. engelhardtii Kvaček differs by the fully papillate abaxial medial area (Kvaček 1976, 1984).

\section{Cephalotaxus Siebold et Zuccarini}

Cephalotaxus pliocaenica Mädler

1939 Cephalotaxus pliocaenica Mädler, p. 18, pl. 1, figs. 6-7, pl. 2, figs. 6-9, text-figs. $3,3,7,9$

Material: The type material is destroyed and no new topotype material is available at SF.

Remarks: Although no material of this conifer described by Mädler (1939) has been recovered in the collections available, the description and illustrations are sufficient for the recognition of this fossil species in the Pliocene flora of Frankfurt/M. Similar needles were recorded in the Romanian Pannonian and assigned to Cephalotaxus pliocaenica by Givulescu (in Givulescu and Olos 1973, p. 32, pl. 12, figs. 4-6, pl. 14, pl. 1, pl. 15, figs. 7-8). A single fragment from the early Miocene Cypris formation of north Bohemia (Kvaček 1984) shows sclereids in the leaf tissue not noticed in the type material of Cephalotaxus pliocaenica Mädler, although it matches the illustrations and descriptions of Mädler (1939) in several other anatomical features. It is also distinguished by the rounded leaf base. Another European Miocene record 


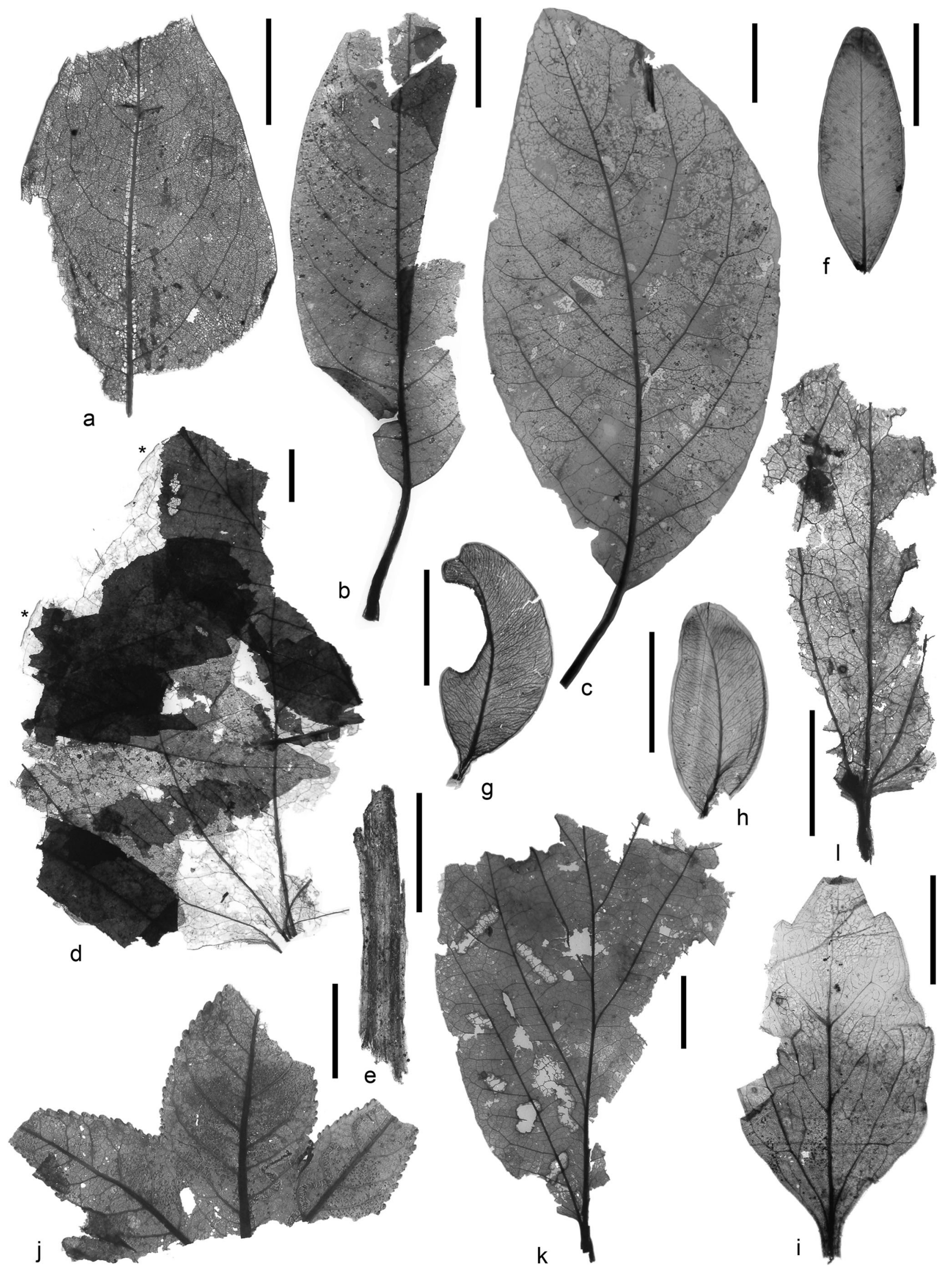


Fig. 3 a Magnolia liblarensis (Kräusel et Weyland) Kvaček, leaf fragment, SF.B 12438, 10 mm. b Magnolia waltheri Kvaček, Teodoridis et Denk sp. nov., incomplete leaf, SF.B 12169, $10 \mathrm{~mm}$. c Sassafras cf. ferretianum Massalongo et Scarabelli, complete leaf, SF.B 12151, $10 \mathrm{~mm}$. d Smilax sp., incomplete leaf with entire margin (stars), SF.B 11529, $10 \mathrm{~mm}$. e Gramineae gen. et sp. indet., leaf fragment, V 26395, $10 \mathrm{~mm}$. f Buxus pliocaenica Saporta, complete leaf, SF.B 12285, 10 mm. g Buxus pliocaenica Saporta, shortly petiolete leaf, S082706, 10 mm. h Buxus pliocaenica Saporta, leafy shoot, S082706, $10 \mathrm{~mm}$. i Pachysandra europaea Kvaček, Teodoridis et Denk sp. nov., incomplete leaf, holotype SF.B 12393, $10 \mathrm{~mm}$. j Liquidambar europaea A. Braun, incomplete pentalobate leaf, SF.B 12158 , $10 \mathrm{~mm}$. k Parrotia pristina (Ettingshausen) Stur, incomplete leaf, SF.B 12161, $10 \mathrm{~mm}$. I Cercidiphyllum crenatum (Unger) R.W. Brown, leaf fragment, SF.B 12466, $10 \mathrm{~mm}$

of Cephalotaxus sp. (according to Kvaček 1976, i.e. Taxus grandis (Steger) Kräusel partim) is too incompletely preserved to be assigned to a fossil species. The Oligocene species C. parvifolia (Walther) Kvaček et Walther differs in smaller needles and indistinctly limited stomata within the stomatal bands (Walther and Kvaček 2007). Comparable fossil species of Cephalotaxus are known also from the Oligocene of China (Shi et al. 2010) and the Miocene of western North America (Kvaček and Rember 2000).

Torreya Arnott

Torreya aff. nucifera Siebold et Zuccarini

Fig. 2r

1908 Torreya nucifera Siebold et Zuccarini fossilis Kinkelin in Engelhardt and Kinkelin, p. 191, pl. 23, figs. 6-8 pro parte (foliage)

1939 Torreya nucifera Siebold et Zuccarini fossilis Kinkelin; Mädler, p. 13, pl. 2, figs. 1-3

Material: All original material listed by Engelhardt and Kinkelin (1908) and Mädler (1939) was destroyed except two needle and epidermis preparations kept at NRM (S082693, S082791). Another specimen was found at the BMNH, V. 17176. No new material is available at SF.

Description: See Mädler (1939, pp. 13-14).

Remarks: The fossil leaf material corresponds in most respects to extant T. nucifera distributed in Japan. A more detailed comparative study of foliage between living and fossil representatives of Torreya is needed to establish their relationships. It is probable that dispersed needles and seeds in the Pliocene of Frankfurt/M. represent a single biological species according to the whole plant concept of Kvaček (2008). In any case, the foliage deserves an independent fossil species name, as done for the seeds (T. schulzii Gregor, van der Burgh, Peters, PingenGregor et al. 2000).

Angiospermae

Magnoliaceae Jussieu
Magnolia Linnaeus subgen. Magnolia Magnolia liblarensis (Kräusel et Weyland) Kvaček

Figs. $3 \mathrm{a}$ and $16 \mathrm{j}-1$

1939 Laubblatt sp.; Mädler, p. 144, pl. 10, fig. 26, pl. 13, figs. 7-9

1959 Papilionaceophyllum liblarense Kräusel et Weyland, p. 111 , pl. 24, figs. $37-41$, pl. 25 , figs. $42-47$, pl. 26 , fig. 48, text-figs. 10-11

1979 Magnolia liblarensis (Kräusel et Weyland) Kvaček, p. 172, pl. 37, figs. $2-5$

Material: SF.B 12438 and cuticle slides B 12438.1, 2.

Description: Fragment of an entire-margined leaf, apex missing, probably acute, lamina $>20 \mathrm{~mm}$ wide, venation brochidodromous, primary vein thick, straight, secondary veins much thinner, widely spaced, looping well within margin, one to four intersecondary veins, tertiary veins sinuous, higher-order veins reticulate. Lamina in transmitted light finely punctate due to secretory cells. Adaxial cuticle smooth, unspecialised cells polygonal, 15-25 $\mu \mathrm{m}$ in diameter, with anticlinal walls narrowly undulating and curved, abaxial cuticle smooth, unspecialised cells polygonal, with $\Omega$-shaped anticlines, paracytic stomatal complexes rounded, $25 \mu \mathrm{m}$ in diameter, guard cell pairs faintly visible within pairs of subsidiary cells, pore linear to very narrow and short, ledges thin, solitary simple rounded trichome bases rarely observed, lenseshaped rounded oil cells in mesophyll tissue of different sizes and frequent.

Remarks: The previously published material identified as "Laubblatt sp. E” by Mädler (1939), p. 144, pl. 10, fig. 26, pl. 13, figs. 7-9) shows the same cuticle pattern and may expand the above characteristics of this record (see detailed morphological description by Mädler 1939 and the reconstructed leaf form of several fragments). Contrary to the type of Magnolia liblarensis from the Rhineland Miocene (Kräusel and Weyland 1959, as Papilionaceophyllum liblarense) and most other Miocene occurrences in Europe (see Kovar-Eder and Hably 2006; Schneider 2004, as Falcicutis varians Schneider), the fragment recovered here as well as the illustrations by Mädler (1939) from the same site differs in glabrous laminas. Thus, the fossil species $M$. liblarensis may turn out to be heterogeneous or is highly variable in pubescence, as documented by Fischer and Butzmann (2000).

Several living Magnoliaceae with similar epidermal patterns (undulate anticlinal walls, rare or lacking pubescence) have been noticed in the modern cuticle collection of $\mathrm{Z}$. Kvaček: Magnolia gustavii King (Assam), M. henryi Dunn (Laos), M. nitida W.W. Smith (Yunnan), M. championii Bentham (Guangxi), M. pterocarpa Roxburgh (Chittagong), M. liliifera (Linnaeus) Baillon (Central Vietnam) and M. elegans (Blume) H. Keng (Java). 
Magnolia subgen. Yulania (Spach) Reichenbach

Magnolia waltheri Kvaček, Teodoridis et Denk sp. nov.

Figs. $3 \mathrm{~b}$ and $16 \mathrm{f}-\mathrm{i}$

Material: SF.B 12153, 12155, 12156, 12169, cuticle slides SF.B 12155.1-4, B 12169.1, 2.

Holotype established here: Specimen SF.B 12155 (fig. 3b), cuticle slides SF.B 12155.1-4.

Derivatio nominis: Remembering late Prof. Harald Walther, expert in fossil leaf morphology and anatomy.

Description: Leaves long petiolate, petiole $>15 \mathrm{~mm}$ long, lamina ovate, $80 \mathrm{~mm}$ long, $>40 \mathrm{~mm}$ wide, entire-margined, apex bluntly acute, base widely cuneate, venation camptodromous, primary vein stout at base, much thinner apically, secondary veins irregularly spaced, more closely spaced at base than towards apex, bent, forked and looping at margin, intersecondaries rare and single, intercostal tertiary veins straight, perpendicular to secondary veins. Adaxial cuticle smooth, hairless, polygonal cells with straight anticlines without thickenings 20-30 $\mu \mathrm{m}$ in diameter, abaxial cuticle very thin, ordinary cells domed, stomata not sunken, brachyparacytic, guard cell pairs broadly elliptic to transversally elliptic, $15 \mu \mathrm{m}$ long, stomatal ledges slightly thickened in the middle, forming spindle-shaped narrow outer aperture. Mesophyll tissue filled with lens-shaped oil cells $25-50 \mu \mathrm{m}$ in diameter

Remarks: Thin cuticles, mesophyll oil cells and the preserved epidermal structure refer these leaf fragments to the Magnoliales. The overall venation and the morphology compare well with foliage of deciduous magnolias. The fragment of $M$. liblarensis described above clearly differs in epidermal patterns, namely the undulate anticlines, non-papillate surface and distinct roundish stomatal complexes. Magnolia waltheri resembles by its stomata patterns Laurophyllum kinkelinii Kvaček (2004) from the Oligocene flora of Flörsheim. Walther (2003), p. 137, text-fig. 3) refers a similar leaf impression from the early Oligocene of Saxony to Magnolia sp. Similarly, so far described Neogene species based on foliage are usually not characterised anatomically (e.g. M. dianae Unger, M. fraterna Saporta, M. mirabilis Kolakovskij), and thus, their affinity to Magnoliales cannot be established with certainty.

Magnolia waltheri matches best in epidermal anatomy (thin cuticles, straight-walled anticlines) and morphology (widely cuneate leaf base, tertiary venation) modern deciduous magnolias, such as Magnolia kobus DC. (Japan). Magnolia salicifolia (Siebold et Zuccarini) Maximowicz (Japan) resembles the fossil species also by its doomed abaxial cells. Magnolia waltheri probably represents foliage belonging to seeds assigned to $M$. cor Ludwig and described from the Pliocene flora of Frankfurt/M. by Mädler (1939). According to Mai $(1975$, p. 564), the seeds are comparable with the extant M. kobus.
Lauraceae Jussieu

Sassafras J. Presl

Sassafras cf. ferretianum Massalongo et Scarabelli

Figs. 3c and 16d, e

Material: SF.B 12151, 12157, cuticle preparations SF.B 12157.1-3.

Description: Leaves petiolate, petiole up to $19 \mathrm{~mm}$ long, lamina ovate, $80 \mathrm{~mm}$ long, 23-40 mm wide, entire-margined, apex bluntly acute, base widely cuneate, venation campto-dromous, primary vein stout at base, much thinner apically, secondary veins irregularly spaced, more closely spaced at base than towards apex, bent, forked and looping at margin, intersecondaries rare and single, intercostal tertiary veins straight, forming acute angles with secondary veins. Adaxial cuticle smooth, hairless, reflecting polygonal cells with straight anticlines without thickenings 20-30 $\mu \mathrm{m}$ in diameter, abaxial cuticle very thin, ordinary cells doomed, stomata not sunken, brachyparacytic, guard cell pairs broadly elliptic to transversally elliptic, $15 \mu \mathrm{m}$ long, stomatal ledges slightly thickened in the middle, forming spindleshaped narrow outer aperture. Mesophyll tissue filled with lensshaped oil cells $25-40 \mu \mathrm{m}$ in diameter.

Remarks: Similar thinly cutinised leaf compressions with oil cells may belong to the Lauraceae, most probably to deciduous plants. The preserved compressions show similar morphological features as the leaf fragment assigned to the same taxon from the Pliocene of Auenheim (Kvaček et al. 2008).

Smilacaceae Ventenat

Smilax Linnaeus

Smilax sp.

Fig. 3d

\section{Material: SF.B 11528, 11529.}

Description: Leaves incomplete, petiolate, lamina broadly ovate, base shallowly cordate-concavo-convex, apex missing, margin entire, venation campylodromous, primary veins 5, secondary veins very thin forming wide meshes with higherorder vein matrix ascending towards the margin and looping far from it.

Remarks: The few foliage remains at hand surely belong to the Smilacaceae because of the characteristic gross morphology and venation. Both specimens fall within the morphological variation of Smilax sagittifera Heer sensu Hantke (1954) and S. weberi Wessel. Similar leaf shapes are found in a great number of modern species (Denk et al. 2015).

Gramineae Jussieu

Gramineae gen. et sp. indet.

Fig. 3e

Material: V.26392, 26393, 26394, 26395. 
Description: Narrowed strip-like leaf fragments, entiremargined and parallel veined.

Remarks: Grass-like foliage fragments not identifiable to a genus noted also by Mädler (1939, p. 49).

Buxaceae Dumortier

Buxus Linnaeus

Buxus pliocaenica Saporta

Figs. $3 \mathrm{f}-\mathrm{h}$ and $16 \mathrm{~m}, \mathrm{n}$

1876 Buxus pliocaenica Saporta in Saporta and Marion, p. 144, pl. 32, figs. 6-8

1908 Buxus sempervirens Linnaeus fossilis Engelhardt in Engelhardt and Kinkelin, p. 260, pl. 33, figs. 1a-r, 2

1939 Buxus sempervirens Linnaeus fossilis Engelhardt; Mädler, p. 109, pl. 13, figs. 1-2

Material: Original slides of Mädler (1939) at Stockholm, S082705, S082706, and at BMNH, V.17174, numerous leaf compressions in glass preparations at SF.

Description: Cuticles of both leaf sides thick, adaxial cuticle reflecting thick-walled unspecialised cells with straight anticlines, only slightly variable in diameter, abaxial cuticle smooth, unspecialised cells similar to those of the abaxial cuticle, stomata anomocytic, broadly elliptic, with I-pieces at poles, ledges thick, forming broadly elliptic pore extending nearly to the poles.

Remarks: Mädler (1939) described for the first time the cuticle structure of this foliage. Subsequent authors (Kvaček et al. 1982, Hably and Kvaček 1997, Kvaček et al. 2008, p. 29) partly revised Mädler's interpretation and recognised the independent status of the fossil species following the original concept of Saporta (in Saporta and Marion 1876) who excluded this fossil species from the modern Buxus sempervirens Linnaeus.

Pachysandra A. Michaux

Pachysandra europaea Kvaček, Teodoridis et Denk sp. nov. Figs. 3i, 160 and $17 \mathrm{a}$

Material: A single leaf compression and cuticle preparations. Holotype: SF.B 12393 (fig. 3i), cuticle preparations SF.B 12393.1-2.

Derivatio nominis: Referring to the typical occurrence of the species.

Description: Leaf ovate, $36 \mathrm{~mm}$ long, $18 \mathrm{~mm}$ wide, coriaceous and thickly cutinised, widely and shallowly bluntly serrate, base decurrent, teeth 3 on each leaf side, their size diminishing towards leaf base, venation pinnate, festooned semicraspedodromous. Adaxial cuticle thick, ordinary cells $38 \mu \mathrm{m}$ in diameter, polygonal, anticlinal cell walls smooth, straight to little curved, abaxial cuticle thick, ordinary cells the same as in adaxial cuticle, stomata broadly elliptic, $50 \times 40 \mu \mathrm{m}$ in size, irregularly orientated, anomocytic (to cyclocytic), with a thick stomatal ring inside, I-pieces at poles, aperture between guard cells linear, short massively cutinised trichomes simple, subulate, $50-80 \mu \mathrm{m}$ long and $30 \mu \mathrm{m}$ thick, on margin. Oil cells in the mesophyll tissue disc-shaped, $30-50 \mu \mathrm{m}$ in diameter.

Remarks: The epidermal structure including the stomata corresponds to the modern representatives of Pachysandra (see also Baranova 1980). Fossils of Pachysandra have been reported from the European Palaeogene as rare seeds (e.g. Mai and Walther 1985, as P. ascidiiformis Mai) and pollen (Krutzsch 1966; also noted in the Eocene of Axel Heiberg Island, McIntyre 1991). To our knowledge, fossil foliage of Pachysandra has not previously been known. Straus (1992, p. 58) mentioned a record of Pachysandra for the Pliocene Willershausen flora without further description or documentation.

Both morphological and leaf anatomical traits of the single compression available indicate its affinity with this evergreen to semi-evergreen subshrub distributed by two or three extant species (P. terminalis Siebold et Zuccarini, P. axillaris Franchet and $P$. stylosa Dunn) in East Asia and by one species (P. procumbens A. Michaux) in southeastern USA. The fossil at hand is best comparable by its glabrous lamina and the leaf form with $P$. terminalis distributed in Japan and China (Gansu, Hubei, Shaanxi, Sichuan, Zhejiang) in shady and damp land in forests at altitudes between 1000 and $2600 \mathrm{~m}$ a.s.l. (Wu and Raven 2008, p. 331). Two other extant species from East Asia; P. axillaris and $P$. stylosa differ by the rounded to cordate leaf base and thick pubescence, $P$. procumbens from the USA by the coarsely toothed margin and hairy leaves, both adaxially and abaxially.

Altingiaceae Lindley

Liquidambar Linnaeus

Liquidambar europaea A. Braun

Fig. $3 \mathrm{j}$

1836 Liquidambar europaea A. Braun in Buckland, p. 513

Material: SF.B 12158.

Description: Leaf incomplete, pentalobate, lobes with glandular crenulate margin.

Remarks: The single specimen of Liquidambar europaea in the Pliocene of Frankfurt/M. confirms the rarity of this element in this flora. It is also known from the carpological record of Frankfurt (Supplementary material File 1). Liquidambar is lacking in the Pliocene of Auenheim (Kvaček et al. 2008) and Willershausen (Knobloch 1998). The pentalobate leaf form of this fossil species is more common than the trilobate one in the late Neogene of Europe (see Knobloch and Kvaček 1976; Hummel 1983). Zhilin (1974) noted that according to Smith (1967) Liquidambar styraciflua produces two leaf forms on every branch differing in the depth of the lobes and the length of the petioles. This variation does not concern the number of lobes, though. According to Hummel (1983), epidermal characteristics 


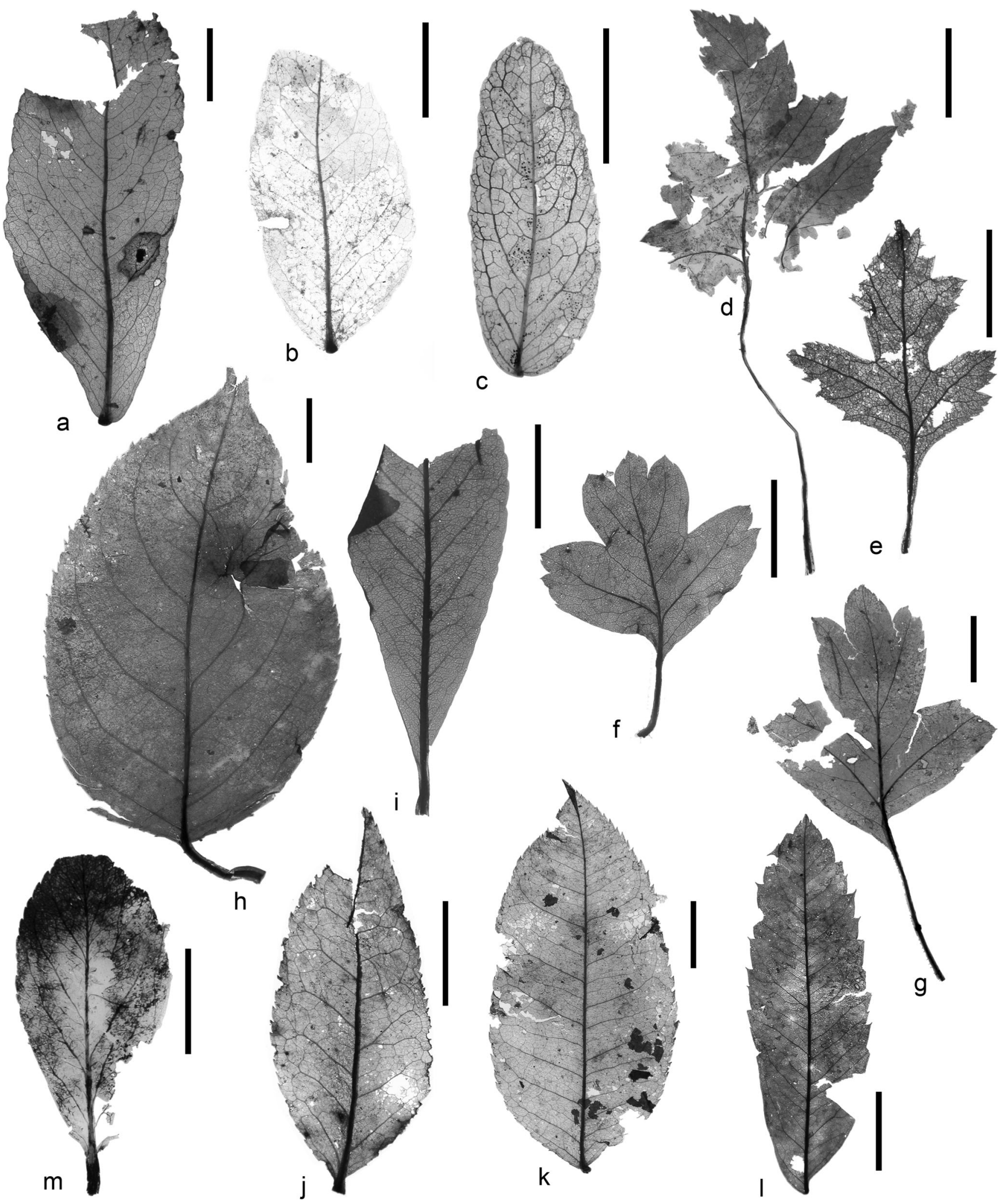

of a pentalobate leaf fragment from the Pliocene of southern Poland indicate a closer relationship of Pliocene records of Liquidambar europaea to the modern $L$. orientalis Miller.
Hamamelidaceae R. Brown

Parrotia C.A. Meyer 
Fig. 4 a Gleditsia pliocaenica Kvaček, Teodoridis et Denk sp. nov., incomplete leaflet, paratype SF.B 12413, $10 \mathrm{~mm}$. b Gleditsia pliocaenica Kvaček, Teodoridis et Denk sp. nov., incomplete leaf, holotype SF.B 12414, $10 \mathrm{~mm}$. c aff. Podocarpium sp., complete leaflet, SF.B 12432, $10 \mathrm{~mm}$. d Crataegus pentagynoides Kvaček, Teodoridis et Denk sp. nov., simple leaf with long petiole, SF.B 12145, $10 \mathrm{~mm}$. e Crataegus pentagynoides Kvaček, Teodoridis et Denk sp. nov., pinnately deeply dissected leaf, V26395, $10 \mathrm{~mm}$. f Crataegus pentagynoides Kvaček, Teodoridis et Denk sp. nov., pinnately deeply dissected leaf, SF.B 12152, $10 \mathrm{~mm}$. g Crataegus pentagynoides Kvaček, Teodoridis et Denk sp. nov., pinnately deeply dissected leaf, SF.B $12170,10 \mathrm{~mm}$. h Malus sp., complete leaf with serrulate margin, SF.B 12165, $10 \mathrm{~mm}$. i ? Prunus sp., incomplete leaf, SF.B 12387, $10 \mathrm{~mm}$. j Rosa sp., complete leaflet, SF.B 12172, 10 mm. k Rosa sp., complete leaflet, SF.B 12171, $10 \mathrm{~mm}$. I Sorbus sp., leaflet, SF.B 12167, 10 mm. m Spiraea sp., obovate leaf, SF.B 12168, $10 \mathrm{~mm}$

\section{Parrotia pristina (Ettingshausen) Stur}

Fig. 3k

1851 Styrax pristinum Ettingshausen, p. 19, pl. 3, fig. 9

1867 Parrotia pristina (Ettingshausen) Stur, p. 192, pl. 5, figs. $2-3$

Material: SF.B 12159, 12161.

Description: Incomplete leaves, 60 and $55 \mathrm{~mm}$ long, 35 and $45 \mathrm{~mm}$ wide, base cuneate to cordate, apex not preserved, margin entire to undulate, venation camptodromous, midrib strong, moderate, secondaries straight, opposite (basal pair) to alternate and looping, tertiary veins perpendicular, straight, venation of higher-order reticulate, veinlets simple branched.

Remarks: A few compression fossils show the characteristic basal venation and asymmetry found in Hamamelidaceae and this fossil species. The material at hand is not complete enough to resolve the exact systematic position of this fossil taxon (see previous discussions in Bůžek 1971; Kvaček et al. 2011). A closely related modern species is Parrotia persica (DC.) C.A. Meyer.

Cercidiphyllaceae Engler

Cercidiphyllum Siebold et Zuccarini

Cercidiphyllum crenatum (Unger) R.W. Brown

Fig. 31

1850 Dombeyopsis crenata Unger, p. 448

1859 Grewia crenata (Unger) Heer, p. 42, pl. 109, figs. 12-21, pl. 110, figs. 1-11

1935 Cercidiphyllum crenatum (Unger) R.W. Brown, p. 575, pl. 68 , figs. $2,6,8-10$

\section{Material: SF.B 12466.}

Description: Leaf fragment, probably ovate, petiolate, $36 \mathrm{~mm}$ long, $14 \mathrm{~mm}$ wide, base rounded, apex not preserved, margin slightly crenulated, venation palmate, primary veins 5 , straight (midrib) to curved (lateral veins), secondary and tertiary veins ramified, areolation poorly developed.
Remarks: A single fragmented leaf compression belongs to this common deciduous element of the northern hemispheric Cenozoic flora based on its morphology (venation palmate, 5veined, margin regularly closely uniformly crenate).

Fossil populations slightly differ in fruit morphology as shown in foliage shoots with attached fruits (Smiley and Rember 1985; Kvaček and Konzalová 1996). It is closely similar to the modern species C. japonicum Siebold et Zuccarini from Japan and China, a deciduous tree inhabiting riparian forests.

Fabaceae Lindley (Leguminosae Jussieu)

Gleditsia Linnaeus

Gleditsia pliocaenica Kvaček, Teodoridis et Denk sp. nov. Figs. $4 \mathrm{a}, \mathrm{b}$ and $17 \mathrm{~b}$

Holotype: Leaflet compression on glass slide SF.B 12414 (fig. 4b) and cuticle preparation SF.B 12414.1 (fig. 17b).

Paratypes: Leaflets SF.B 12412-12413, 12415-12422.

Derivatio nominis: Referring to the geological age of the Klärbeckenflora, Frankfurt/M.

Description: Leaflets detached, sessile or exceptionally with very short petiolule, $22-40 \mathrm{~mm}$ long, $12-33 \mathrm{~mm}$ wide, narrowly to broadly ovate, base asymmetrical, rounded to cuneate, apex broadly acute, margin irregularly, simple bluntly serrate except entire-margined base, teeth simple, shallow asymmetrically rounded, venation semicraspedodromous, craspedodromous, primary vein straight or slightly curved, secondary veins in up to seven pairs with single intersecondaries, looping widely along the margin, lateral veinlets entering the margin into teeth, tertiary veins forming asymmetrical meshes with higher-order vein matrix. Epidermal structure of the holotype: adaxial cuticle smooth, ordinary cells polygonal, $25-40 \mu \mathrm{m}$ in diameter, anticlinal walls slightly bent, simple thin trichomes up to $150 \mu \mathrm{m}$ dispersed on veinlets, abaxial cuticle smooth, ordinary cells with curved or bent anticlinal walls, mostly $30 \mu \mathrm{m}$ in diameter, over veins quadrangular, $12-15 \mu \mathrm{m}$ wide, 25-75 $\mu \mathrm{m}$ long, solitary elliptical thin-walled trichome bases $25 \times 15 \mu \mathrm{m}$ in size, stomata irregularly disposed, elliptic, irregularly sized, average $25 \mu \mathrm{m}$ long, $15 \mu \mathrm{m}$ wide, ? anomocytic, stomatal ledges slightly thickened, aperture boat-shaped, slit linear.

Remarks: Similar leaflets were described as Gleditsia by Guo and Zhou (1992) from the Miocene of China and by Kvaček et al. (2011) from the Miocene of southwestern Europe (Arjuzanx). Gleditsia suevica Rüffle (1963) and the foliage described as Podogonium oehningense (Koenig) Kirchheimer sensu Rüffle (1963) of the Miocene of Germany show a similar structure of the adaxial as well as abaxial epidermis and pubescence but differ by the entire margin and petiolulate leaflets. The modern Gleditsia caspica Desfontaines produces similar foliage and might be the closest 
extant relative of the fossil taxon; it is a typical element of the lowland Hyrcanian forests associated with other relic elements, such as Pterocarya, Albizzia and Parrotia (Denk 1998). Gleditsia pliocaenica differs from G. caspica in broader asymmetrically ovate leaflets and a distinctly crenulate lamina.

aff. Podocarpium A. Braun

aff. Podocarpium sp.

Fig. 4c

Material: SF.B 12432.

Description: Leaflet, sessile, narrow ovate, $25 \mathrm{~mm}$ long, $9 \mathrm{~mm}$ wide, rounded at base and apex, margin almost entire, venation brochidodromous, primary vein slightly bent, secondary veins steep, in six pairs, with rare single intersecondaries, tertiary veins reticulate.

Remarks: The single specimen is similar to Gleditsia pliocaenica based on its venation but might belong to a different genus of the legumes. Leaflets of Podocarpium podocarpum (A. Braun) Herendeen widely distributed in the European Neogene differ in fully entire margins and one stronger basal, asymmetrically disposed, secondary vein (Bůžek 1971, p. 98).

Rosaceae Jussieu

Crataegus Linnaeus

Crataegus pentagynoides Kvaček, Teodoridis et Denk sp. nov.

Fig. $4 d-g$

? 1855 Crataegus oxyacanthoides Göppert, (non Thuill.), pp. 38-39, pl. 26, fig. 1, nom. illegit

? 1930 Crataegus oxyacantha Linnaeus; Straus, p. 31, pl. 37, fig. 8 , pl. 41, figs. 10-11

1992 Crataegus cf. oxyacantha Linnaeus fossilis (= C. laevigata $)$; Straus, p. 52

1998 Crataegus aff. oxyacanthoides Göppert; Knobloch, p. 67 , pl. 39 , figs. 6-7

Holotype established here: SF.B 12170 (Fig. 4g).

Paratypes: SF.B 12152, 12154, 12166.

Derivatio nominis: Expressing similarity to the foliage to the modern Crataegus pentagyna Waldstein.

Description: Leaves simple, long petiolate, petiole up to $30 \mathrm{~mm}$ long, lamina up to $35 \mathrm{~mm}$ long, 20-35 mm wide, pinnately deeply dissected into 1-2 pairs of simple, widely serrate lobes departing from main axis at $90^{\circ}$ or at very wide angles.

Remarks: Such leaves are rarely found in the European Pliocene and have usually been ascribed to Crataegus (e.g. from the Hungarian site Pula, Hably and Kvaček 1997; and from the German Pliocene of Willershausen, Knobloch 1998) but a closer assessment of the relationship has been rarely attempted. Indeed, the foliage alone may hardly afford a firm basis to determine the systematic position of a fossil species of Crataegus without details of pubescence, position of the leaf within the crown and without any other organs of the mother plant. Similar deeply dissected leaves are found in sect. Pentagyna in modern C. pentagyna (syn. C. melanicarpa Bieberstein) native to eastern South Europe, the Caucasus and Iran. Similar leaf forms are produced also in sect. Crataegus, e.g. C. sakranensis Hadač et Chrtek, C. longipes Pojarkova ex Christensen (see Christensen 1992).

Malus Miller

Malus sp.

Fig. $4 \mathrm{~h}$

Material: SF.B 12165.

Description: Leaf petiolate, petiole $13 \mathrm{~mm}$ long, lamina ovate, $78 \mathrm{~mm}$ long, apex acuminate, base obtuse to widely cuneate, margin simple serrulate, venation eucamptodromous to brochidodromous, secondary veins irregularly spaced, strongly bent, small veins departing from secondary veins and entering teeth.

Remarks: This single compression matches in leaf morphology, particularly the acuminate apex, leaves of the modern Malus baccata (Linnaeus) Borkhausen ("Siberian crab apple") from northern Asia. The European M. sylvestris Miller differs in the short acute apex. Knobloch (1998) stated that his fossil species Dicotylophyllum kvacekii Erw. Knobloch (1998, p. 84, pl. 62, fig. 3) from the Pliocene of Willershausen showed a leaf gross morphology similar to Euonymus Linnaeus due to the characteristic venation, but also to Malus. Fossils of Malus are extremely rare, e.g. a carpological record from the Pliocene-Pleistocene of Italy (Martinetto et al. 2007).

Prunus Linnaeus

? Prunus sp.

Figs. $4 \mathrm{i}$ and $17 \mathrm{c}-\mathrm{e}$

2008 Dicotylophyllum cf. heerii Kvaček et Walther; Kvaček et al., p. 39, pl. 13, figs. 9-13, pl. 23, figs. 1-2

Material: SF.B 12387, cuticle preparations SF.B 12387.1-3. Description: Leaf base cuneate, lamina $38 \mathrm{~mm}$ long, short petiolate, petiole fragmentary, lamina crenulate, primary vein firm, secondary veins simple or forking, intersecondaries present, secondary venation brochidodromous, small veins entering crenations, tertiary veins oblique to secondary veins, secondary veins to higher-order veinlets prominent, adaxial cuticle medium thick, smooth, outlines of unspecialised cells polygonal, anticlinal walls fine shallow undulate, trichome bases thickly cutinised, simple, rounded, star-like and surrounded by a simple ring of five subsidiary cells that are staining darker 
than ordinary cells, mainly present on veins, abaxial cuticle slightly granular, smooth over veins, unspecialised cells polygonal, with strongly undulate anticlines, stomata cyclocytic, rarely anisocytic, guard cell pairs broadly elliptic, to circular, 25-37 $\mu \mathrm{m}$ long and 20-25 $\mu \mathrm{m}$ wide, periphery and ledges punctate, pore broadly elliptic, $12 \mu \mathrm{m}$ long, $10 \mu \mathrm{m}$ wide, Ipieces thin., subsidiary cells 5-6 arranged in a simple ring, slightly darker than unspecialised cells.

Remarks: Similar leaf compressions were referred to as Dicotylophyllum cf. heerii (Engelhardt) Kvaček et Walther in the Pliocene of Auenheim (Kvaček et al. 2008, p. 39, pl. 13, figs. 9-13, pl. 23, figs. 1-2) and compared to Prunus laurocerasus Linnaeus. The Miocene flora of Arjuzanx included also leaf compressions having similar leaf morphology and epidermal anatomy (as "Viburnum" atlanticum Ettingshausen, Kvaček et al. 2011, pro parte, pl. 8, fig. 24). A possible modern analogue is Prunus laurocerasus Linnaeus from southeastern Europe to northern Iran or P. lusitanica Linnaeus from southern Europe, Madeira to the Canary Islands. The epidermal structure, namely cyclocytic, rarely anisocytic stomata and trichome bases on both leaf sides, makes the comparison with Prunus laurocerasus with hairless leaves equivocal. Similar epidermal structure is found in some Theaceae. Prunus lusitanica differs in incompletely amphicyclocytic stomata (Rasche and KovarEder 2009). The so far described fossil records compared with Prunus laurocerasus Linnaeus are from upper Oligocene deposits of Kazakhstan (see Zhilin 1974, as Laurocerasus praeofficinalis Zhilin) to Pliocene deposits of southern Europe (as Laurocerasus officinalis Roemer pliocenica Laurent see Marty in Laurent 1904 or Laurocerasus officinalis Roemer fossilis see Palamarev et al. 2005), but none of them was confirmed by the leaf epidermal structure.

Rosa Linnaeus

Rosa sp.

Fig. $4 \mathrm{j}, \mathrm{k}$

Material: SF.B 12171, 12172, 12173, 12174, 12175.

Description: Leaflets with sharply simple serrate margin and dense semicraspedodromous rosoid venation.

Remarks: Similar foliage was described from various European Miocene floras, e.g. Kreuzau (Ferguson 1971, as Taxon No. XXXI. Rosa). The available remains consisting of isolated and mostly fragmentary leaflets are difficult to compare to particular modern or fossil species.

Sorbus Linnaeus

Sorbus sp.

Fig. 41

Material: SF.B 12167.

Description: A single detached leaflet, sessile, oblong, base asymmetrical, apex bluntly acute, coarsely simple serrate to entire-margined, venation craspedodromous and eucaptodromous (when entire-margined), primary vein straight, secondary veins regularly spaced, bent, occasionally forking, secondary veins in up to $15-18$ pairs, marginal teeth simple apiculate.

Remarks: The leaflet belongs to a compound leaf because of its sessile asymmetrical base. Venation and serration patterns place this single specimen into Sorbus sect. Sorbus. Epidermal details were not observed. The modern species $S$. aucuparia Linnaeus (Europe) and S. americana Marshall are closely similar. Of several fossil species, none matches exactly in morphological details (e.g. Sorbus lanceolata Tanai et Suzuki 1965 from the Neogene of Japan with widely disposed teeth on leaflets, Sorbus cf. uzenensis Huzioka sensu Erw. Knobloch 1998 with dense marginal serration).

Spiraea Linnaeus

Spiraea sp.

Fig. $4 \mathrm{~m}$

Material: SF.B 12168.

Description: Leaf obovate, shortly petiolate, petiole stout, $3 \mathrm{~mm}$ long, lamina $30 \mathrm{~mm}$ long, $15 \mathrm{~mm}$ wide, finely serrate in the upper half, below entire-margined, venation eucamptodromous and craspedodromous, primary vein straight, secondary veins in eight pairs, in the lower part steep, higher up at moderate angles, with densely spaced lateral veinlets entering the teeth, tertiary veins oblique to the secondary veins.

Remarks: This is the only leaf compression referable by its morphology to Spiraea. Of the living representatives, mostly deciduous shrubs distribute in temperate Eurasia and North America. Several extant species are fairly similar to the fossil, e.g. S. trichocarpa Nakai of Korea and S. douglasii Hooker (incl. subsp. menziesii (Hooker) Calder et Roy L. Taylor) of western North America. The fossil is different from S. salicifolia Linnaeus of southern Europe to Asia by the entire-margined lower part of the lamina.

Ulmaceae Mirbel

Ulmus Linnaeus

Ulmus carpinoides Göppert

Fig. 5b

1855 Ulmus carpinoides Göppert, p. 28, pl. 13, figs. 4-6

Material: SF.B 11759, 12076, 12077, 12085, 12102.

Description: Leaves simple, petiolate, petiole 3 and $>3 \mathrm{~mm}$ long, lamina ovate, $>30 \mathrm{~mm}$ long, $22-60 \mathrm{~mm}$ wide, margin double serrate, teeth short, apically curved, venation craspedodromous, primary vein straight, strong, secondary veins densely spaced, in 12-22 pairs, basally departing at wide, higher up at steeper angles, subparallel, tertiary veins very thin, reticulate between secondary veins. 
Fig. 5 a Ulmus pyramidalis Göppert., complete leaf, SF.B 12101, $10 \mathrm{~mm}$. b Ulmus carpinoides Göppert, complete leaf, SF.B 12077, $10 \mathrm{~mm}$. c Zelkova zelkovifolia (Unger) Bůžek et Kotlaba, foliage shoot, SF.B 12016, $10 \mathrm{~mm}$. d Zelkova zelkovifolia (Unger) Bůžek et Kotlaba, complete leaf, SF.B $12018,10 \mathrm{~mm}$

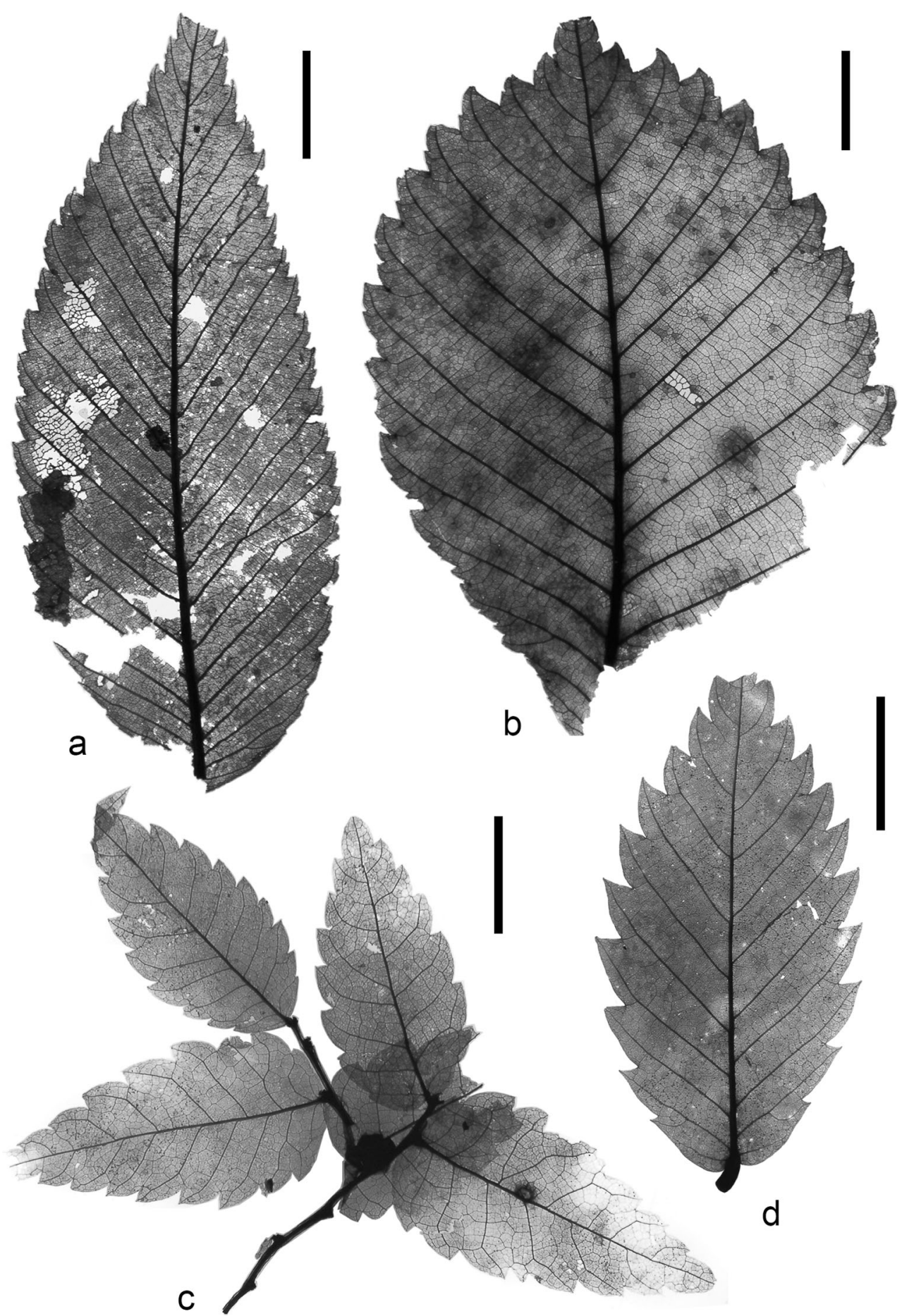

Remarks: Specimens of this kind of elm foliage from our collection of the Frankfurt flora fall within the morphological variability of Ulmus carpinoides described from the late Miocene locality Sośnica. The leaves at Sośnica are accompanied by two kinds of fruits, one ascribed to U. pyramidalis (see below) and another one, more rounded, corresponding to the living $U$. campestre Linnaeus ( $Z$. Kvaček, personal observation). The latter fruit type may belong to the foliage of the fossil species $U$. carpinoides.

Ulmus pyramidalis Göppert

Fig. 5a

1855 Ulmus pyramidalis Göppert, p. 28, pl. 13, figs. 10-12 
1839 Ulmus longifolia Unger; Mädler, p. 86, pl. 8, fig. 1

Material: SF.B 11781, 12093, 12097, 12101.

Description: Leaves simple, shortly petiolate, petiole 2$6 \mathrm{~mm}$ long, lamina lanceolate, $30-50 \mathrm{~mm}$ long, 6$13 \mathrm{~mm}$ wide, margin double serrate, teeth short, apically curved, venation craspedodromous, primary vein straight, strong, secondary veins densely arranged in 20 pairs, basally departing at wide angles, higher up at moderate angles, subparallel, tertiary veins thin, sinuous and densely arranged between secondaries.

Remarks: Similar fossil leaves have been ascribed to Ulmus pyramidalis from the late Miocene locality Sośnica and many other sites in the European Miocene (for synonyms, see Bůžek 1971). In the early Miocene flora of northern Bohemia, this foliage is accompanied by long-stalked samaras with a calyx remain above the stalk base (Bůžek 1971). The modern $U$. americana Linnaeus or $U$. alata Michaux from North America have been indicated as the nearest living species but they differ in the morphology of the fruits (position of the calyx).

\section{Zelkova Spach}

Zelkova zelkovifolia (Unger) Bůžek et Kotlaba

Fig. 5c, d

1845 Ulmus zelkovifolia Unger, pl. 24, figs. 9-13 (non fig. 7) 1939 Zelkova ungeri Kováts; Mädler, p. 88, pl. 8, figs. 3-5 1963 Zelkova zelkovifolia (Unger) Bůžek et Kotlaba in Kotlaba, p. 59, pl. 3, figs. $7-8$

Material: Original material of Mädler (1939) V. 17173, V.26383, V.25384 and Stockholm S127818, new slides at SF.B 11986, 12004, 12016, 12018, 12049, 12062.

Remarks: Leaves and foliage shoots listed above correspond in leaf morphology to the type material of Ulmus zelkovifolia (i.e. Zelkova zelkovifolia) from Parschlug and other sites in the European Neogene. They are well comparable with some of the relictual modern species distributed in the Caucasus and south of the Caspian Sea and in southern Europe (Denk and Grimm 2005).

Fagaceae Dumortier

Fagus Linnaeus

Fagus kraeuselii Kvaček et Walther

Fig. 6b, c

1939 Fagus ferruginea Aiton fossilis Nathorst; Mädler, p. 83, pl. 7 , figs. 21,22

1939 Fagus decurrens Reid; Mädler, p. 84, pl. 7, figs. 28, 29

1991 Fagus kraeuselii Kvaček et Walther, p. 488, pls. 19-20, text-fig. $11 \mathrm{~b}$

2001 Fagus kraeuselii Kvaček et Walther; van der Burgh, p. 290, pl. 2, figs. 3-6, 8-9
2004 Fagus haidingeri Kováts; Denk, p. 11, pro parte, figs. 13B, G, 14D, E, M

Material: Numerous leaf compressions including the holotype SF.B 1197 and the paratypes SF.B 11902-11903, epidermal preparations KN 1/89-KN 7/89 (MMG), one leaf compression at Stockholm (S127837).

Description: For detailed description and synonymy, see Kvaček and Walther (1991) and Denk (2004).

Remarks: According to Kvaček and Walther (1991) and van der Burgh (2001), only biometrical differences have been detected between foliage of the Pliocene populations of Fagus kraeuselii and the late Miocene F. menzelii Kvaček et Walther and F. silesiaca Walther et Zastawniak. According to Denk (2004), late Miocene and Pliocene Fagus foliage previously assigned to various fossil species ( $F$. pliocaenica Saporta, F. kraeuselii, F. silesiaca) should be included within F. haidingeri Kováts described from upper middle Miocene deposits of Hungary. Mädler (1939) compared two fossil species of Fagus from Frankfurt to the modern North American F. grandifolia Ehrhart (as F. ferruginea Aiton) and to the Eurasian F. sylvatica Linnaeus and F. crenata Blume (as F. sieboldi Siebold et Zuccarini). According to Denk (2004), the closest similarity of the Frankfurt specimens is with the modern East Asian F. crenata Blume and F. hayatae Palibin ex Hayata.

\section{Castanea Miller}

Castanea sp.

Figs. 6a and 17f, g

1983 Castanea cf. sativa Miller sensu Hummel, p. 29, pl. 14, figs. 1-3a, pl. 15, figs. $1-5$, text-figs. 12.1-15, 13.1, 14.1

Material: SF.B 11836, cuticle preparations SF.B 11836.1-2. Description: Leaf fragment, petiolate, petiole $>20 \mathrm{~mm}$ long, lamina $>60 \mathrm{~mm}$ long, $>20 \mathrm{~mm}$ wide, base obtuse to shallowly cordate, primary vein straight and strong, secondary venation craspedodromous/semicraspedodromous, secondary veins evenly spaced, straight, ending in a bristle tooth, tertiary veins perpendicular to secondary veins, branching or more rarely percurrent, marginal (fimbrial) vein present. Cuticles extremely thin, adaxial not preserved, abaxial on veins with narrow straight-walled cells, unspecialised cells polygonal with anticlinal walls straight to slightly curved, stomata anomocytic, seen as elliptical guard cell pairs $25 \mu \mathrm{m}$ long and $17 \mu \mathrm{m}$ wide, ledges broad, but not thickened, pore narrow elliptical, $12 \mu \mathrm{m} \times 10 \mu \mathrm{m}$ in size, solitary trichome bases ca. $15 \mu \mathrm{m}$ in diameter with asymmetrical attachment of distal gland.

Remarks: The fragmentary specimen investigated agrees in the details of marginal venation and its epidermal anatomy with the material from the Pliocene site Ruszów, Poland, assigned to Castanea cf. sativa Miller (Hummel 1983). 


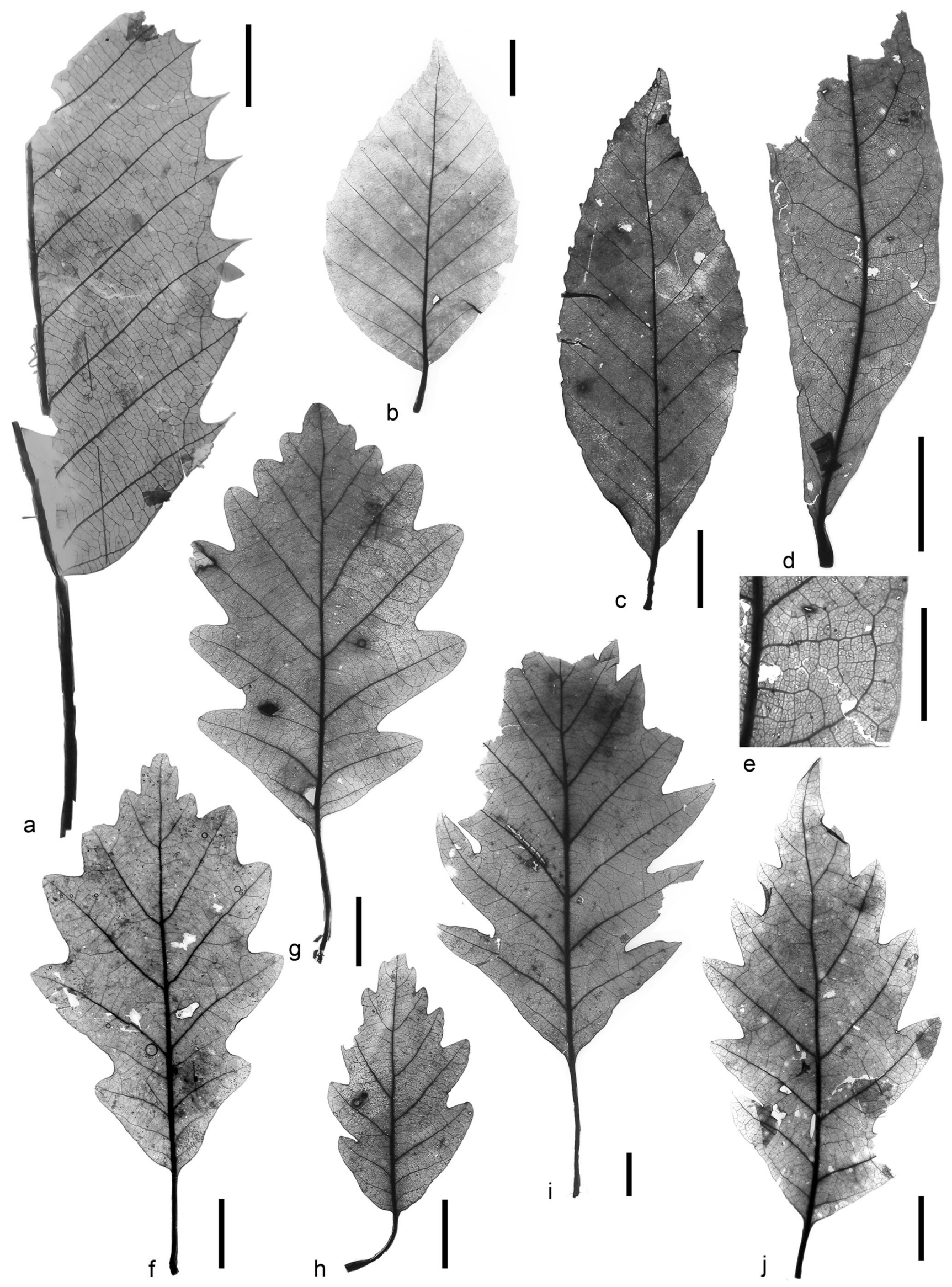


Fig. 6 a Castanea sp., fragmentary leaf with long petiole, SF.B 11836, $10 \mathrm{~mm}$. b Fagus kraeuselii Kvaček et Walther, complete leaf, SF.B 11907, 10 mm. c Fagus kraeuselii Kvaček et Walther, complete leaf, SF.B 11963, $10 \mathrm{~mm}$. d Quercus sp., incomplete leaf, SF.B 11643, $10 \mathrm{~mm}$. e Quercus sp., detail of leaf lamina, SF.B 11643, 5 mm. f Quercus roburoides Gaudin sensu Erw. Knobloch, lobate leaf, SF.B 11805, 10 mm. g Quercus roburoides Gaudin sensu Erw. Knobloch, lobate leaf, SF.B 11831, $10 \mathrm{~mm}$. h Quercus roburoides Gaudin sensu Erw. Knobloch, lobate leaf, SF.B 11824, $10 \mathrm{~mm}$. i Quercus pseudocastanea Göppert sensu Walther et Zastawniak, lobate leaf, SF.B 11834, 10 mm. j Quercus roburoides Gaudin sensu Erw. Knobloch, lobate leaf, SF.B 11843, $10 \mathrm{~mm}$

Mädler (1939), pl. 7, figs. 19, 20) figured two specimens as Castanea sp. These specimens are very fragmentary and do not show much venation details. They are, however, more similar to the type of Quercus foliage described below as aff. Q. kubinyii (Kováts ex Ettingshausen) Czeczott.

\section{Quercus Linnaeus}

aff. Quercus kubinyii (Kováts ex Ettingshausen) Czeczott

Fig. $7 \mathrm{a}$

1852 Castanea kubinyi Kováts, Ettingshausen, p. 6, pl. 1, fig. 12

1939 Castanea sp.; Mädler, p. 79, pl. 7, figs. 19, 20

1951 Quercus kubinyii (Kováts ex Ettingshausen) Czeczott, p. 392, fig. 7

Material: SF.B 11844a.

Description: Leaf fragment, margin regularly sharply dentate, teeth long acuminate, ending in a bristle, sinuses rounded, venation craspedodromous, primary vein stout, secondary veins simple, departing from primary vein at an angle of $60^{\circ}$, straight, marginal vein weakly developed, cuticle not accessible.

Remarks: The exact botanical affinity of this specimen is difficult to establish without information about the epidermal structure. Nevertheless, the marginal venation suggests Quercus rather than Castanea (for details, see Hummel 1983).

Quercus roburoides Gaudin sensu Erw. Knobloch

Figs. $6 \mathrm{f}-\mathrm{h}, \mathrm{j}$ and $17 \mathrm{~h}$

1859 Quercus roburoides Gaudin in Gaudin and Strozzi, p. 44,58 , pl. 3 , fig. 14

1908 Quercus robur Linnaeus pliocaenica Engelhardt in Engelhardt and Kikelin, p. 234, pro parte, pl. 28, fig. 18a

1939 Quercus sessiliflora Salisbury fossilis sensu Mädler, p. 78, pro parte, pl. 7, fig. 18

1998 Quercus roburoides Gaudin; Knobloch, p. 32, pl. 6, fig. 4, pl. 12 , figs. $1-3$, pl. 13 , figs. $1-3$, pl. 14 , figs. $1-2$, pl. 17 , fig. 4

Material: SF.B 11805, 11824, 11831, 11842, 11843, cuticle preparations SF.B 11805.1-2.
Description: Leaves long petiolate, lamina elliptic to obovate, margin distinctly lobate, lobes rounded, more than six on each side, sinuses rounded, venation craspedodromous, primary vein stout, secondary veins simple, originating at an angle of $60^{\circ}$, straight, marginal vein weakly cuticle features similar in structure to the following fossil species.

Remarks: These leaves are closely similar to the modern Q. petraea (Mattuschka) Lieblein and allied taxa (Q. dalechampii Tenore, Q. iberica Steven ex M. Bieberstein, Q. dshorochensis K. Koch).

Quercus pseudocastanea Göppert sensu Walther et Zastawniak

Figs. 6i and $17 \mathrm{i}$

1908 Quercus robur Linnaeus pliocaenica Engelhardt in Engelhardt and Kinkelin, p. 234, pl. 28, fig. 18b-k

1939 Quercus sessiliflora Salisbury fossilis Mädler, p. 78, pro parte, pl. 7, fig. 17

1991 Quercus pseudocastanea Göppert sensu Walther et Zastawniak, p. 169, pro parte, pl. 2, figs. 2-3, pl. 3, figs. $1-6$, text-figs. $8.2-5,7$

Material: SF.B 11786, 11818, 11827, 11834, cuticle preparations SF.B 11786.1-3.

Description: Leaves long petiolate, lamina elliptic to obovate, margin distinctly lobate, lobes rounded to acute, venation craspedodromous, primary vein stout, secondary veins simple, originating at an acute angle, straight. Abaxial cuticle smooth, delicate, unspecialised cells not visible in the preserved cuticle structure, stomata anomocytic (?), uniformly sized, $25 \mu \mathrm{m}$ long, 15-20 $\mu \mathrm{m}$ wide, pore narrow elliptic, short, stellate trichomes mostly four-armed, rarely encountered on veins, glandular trichomes with serial base, dense, occasionally in pairs, basal cell cylindrical, $12 \mu \mathrm{m}$ in diameter, with attached short remain of distal part, simple rounded trichome bases $10 \mu \mathrm{m}$ in diameter with thickened margin, scattered on veins.

Remarks: According to Knobloch (1998) and Worobiec and Szynkiewicz (2016), Quercus pseudocastanea differs from $Q$. roburoides by acute lobes. The cuticle structure, which is the same for both forms, does not support such a distinction and hence it may be reasonable to maintain a broad concept of fossil roburoid oaks (Iljinskaya in Takhtajan 1982; van der Burgh 2001).

Quercus praecastaneifolia Erw. Knobloch

Figs. $7 \mathrm{~b}-\mathrm{f}$ and $17 \mathrm{j}$

? 1964 Quercus kodorica Kolakovskii, p. 84, pro parte, pl. 29, fig. 1

1991 Quercus pseudocastanea Göppert sensu Walther et Zastawniak p. 169, pro parte, pl. 2, figs. 5-6, text-figs. $8.1,8.6$ 


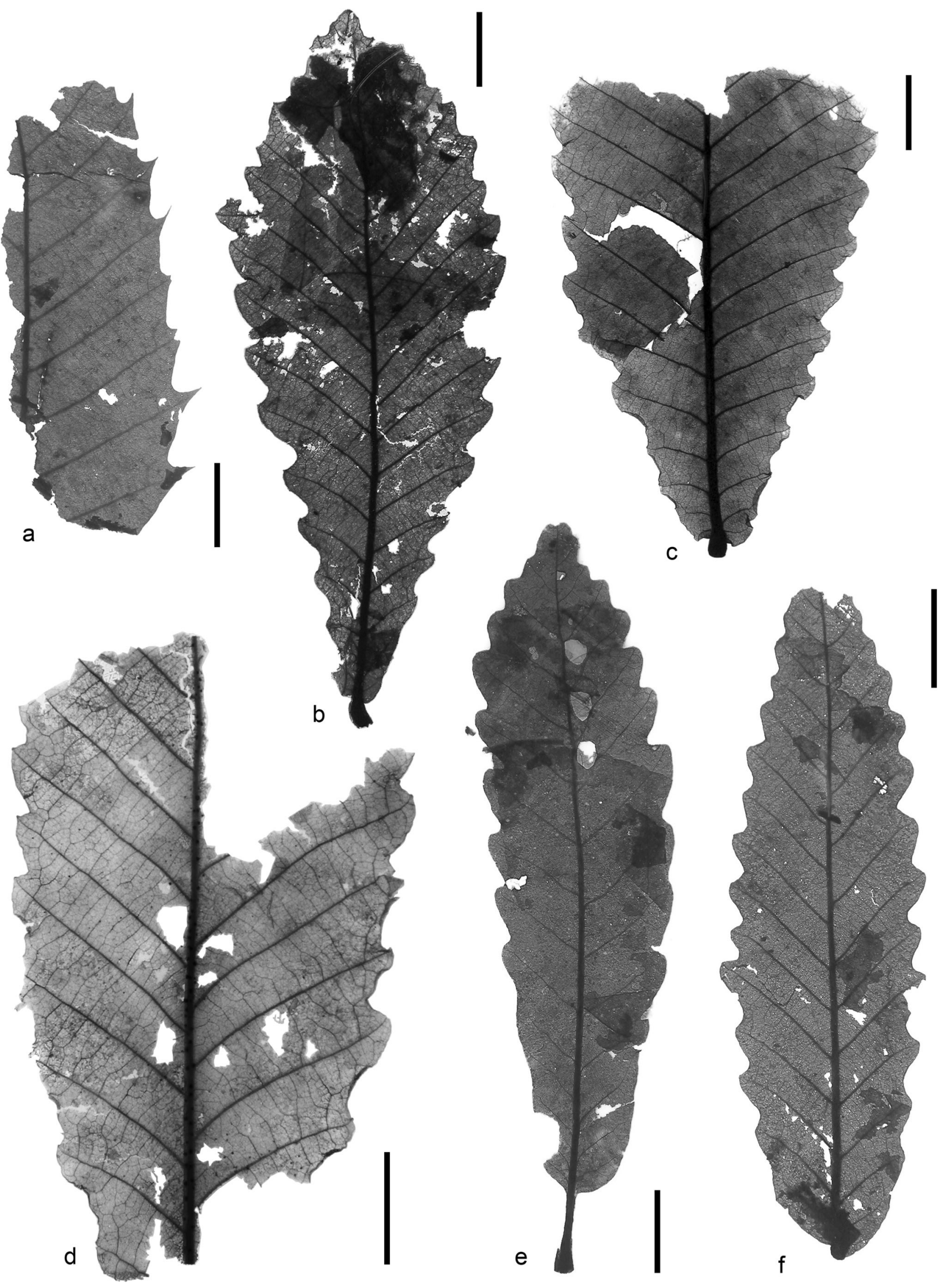


Fig. 7 a aff. Quercus kubinyii (Kováts ex Ettingshausen) Czeczott, fragmentary leaf, SF.B 11844a, $10 \mathrm{~mm}$. b Quercus praecastaneifolia Erw. Knobloch, complete leaf, SF.B sn11, $10 \mathrm{~mm}$. c Quercus praecastaneifolia Erw. Knobloch, incomplete leaf, SF.B 11844b, $10 \mathrm{~mm}$. d Quercus praecastaneifolia Erw. Knobloch, incomplete leaf, SF.B 11855, 10 mm. e. Quercus praecastaneifolia Erw. Knobloch, complete leaf, SF.B 11850, $10 \mathrm{~mm}$. $f$ Quercus praecastaneifolia Erw. Knobloch, complete leaf, SF.B 11845, $10 \mathrm{~mm}$

1998 Quercus praecastaneifolia Erw. Knobloch, p. 30, pl. 13, fig. 4 , pl. 15 , figs. $1-6$, text-fig. $11 \mathrm{a}-\mathrm{b}$

Material: SF.B 11790, 11844b, 11845, 11850, 11855, sn11, cuticle preparations SF.B 1179.1, sn.11.1-2.

Description: Leaves shortly petiolate, lamina narrow obovate, apex bluntly acute, base shortly cuneate to rounded to shallowly subcordate, auriculate, margin regularly shallowly lobate with up to 16 lobes on each side of lamina, lobes blunt or indistinctly mucronulate, sinuses rounded, venation craspedodromous, primary vein straight, secondary veins in up to 18 pairs, regularly spaced, pinnate, adaxial cuticle medium thick, smooth, unspecialised cells polygonal, straight-walled, abaxial cuticle thin, smooth, unspecialised cells not well discernible, stomata anomocytic, elliptic, $20 \mu \mathrm{m}$ long, $15 \mu \mathrm{m}$ wide, pore short, slitlike, stellate trichomes scattered, two- to eight-armed, bases of glandular trichomes on veins, rare.

Remarks: According to Uzunova and Palamarev (1993), species of Quercus section Quercus (white oaks; Denk et al. 2017) have anomocytic stomata, while sections Ilex and Cerris are characterised by cyclocytic stomata. If this is a consistent feature, the leaves at hand would belong to white oaks. The narrow elongated, auriculate leaf base, rounded sinuses between the teeth, and absence of bristle-like extensions of the secondary veins also are suggestive of white oaks rather than section Cerris. Specifically, the investigated leaves have various features typical of white oaks from East Asia (e.g. Q. griffithii Hook.f. and Thomson ex Miquel, Q. aliena Blume, Q. dentata Thunberg in Murray; Supplementary material File 3). Knobloch (1998) compared such leaves from the Pliocene locality Willershausen with the modern Q. castaneifolia C.A. Meyer and established a new species Q. precastaneifolia. Most probably, this fossil species belongs to the white oaks and represents an extinct Pliocene species that did not survive into modern times.

\section{Quercus sp.}

Figs. 6d, e and $17 \mathrm{k}$

Material: SF.B 11643, cuticle preparations SF.B 11643.1-2. Description: Leaf incomplete, short petiolate, petiole $4 \mathrm{~mm}$ long, proximal part conspicuously dilated, only lower part of lamina preserved, entire-margined, $16 \mathrm{~mm}$ wide, incomplete length $47 \mathrm{~mm}$, on one side with two shallow lobes giving the margin an undulating appearance, venation brochidodromous, primary vein slightly bent, secondaries irregularly spaced, departing from primary vein at angles of $35-40-50^{\circ}$, partly with single intersecondaries perpendicular to primary vein, tertiary veins mixed percurrent, exterior tertiaries looped, areolation well developed, adaxial cuticle delicate, ordinary cells polygonal, straight-walled, solitary rounded trichome bases, abaxial cuticle smooth, very thin, ordinary cells not recognisable, stomata seen as elliptical outlines $15 \mu \mathrm{m}$ long with very narrow stomatal ledges, appearing anomocytic, bases of serial glandular trichomes thin-walled, $12 \mu \mathrm{m}$ in diameter with incomplete terminal parts up to $25 \mu \mathrm{m}$ long and pearlike basal cells dispersed among stomata.

Remarks: The leaf is very delicate, characteristic of deciduous foliage. The glandular indumentum is comparable with serial trichomes in the Fagaceae. The morphology suggests an aberrant leaf form of Quercus robur Linnaeus. Similar leaf forms, but with longer petioles, have been recovered in Neogene deposits of northern Greece, Vegora mine (Kvaček et al. 2002, pl. 14, fig. 5) and assigned to Q. pseudocastanea Göppert. The structure of the thin cuticle with only bases of glandular trichomes matches the above-mentioned leaf compressions assigned to Quercus praecastaneifolia. Such narrow leaf forms are produced by oak cultivars, such as Quercus petraea "laciniata" but also occur as variants of Q. infectoria Oliver (var. pfaeffingeri (Kotschy ex Tchichatcheff) Jamzad et Panahi). Alternatively, similar leaf forms may be encountered in North American deciduous swamp oaks of sect. Lobatae.

Juglandaceae DC. ex Perleb

Carya Nuttall

Carya sp.

Fig. 8a, b

1908 Carya sp.; Engelhardt and Kinkelin, p. 241, pl. 31, fig. 7 1908 Pterocarya denticulata (Weber) Heer; Engelhardt and Kinkelin, p. 242, pl. 31, fig. 8a-d

1939 Pterocarya denticulata (Weber) Heer; Mädler, p. 57, pl. 6, figs. 16-19 (? non fig. 3, fruit)

Material: SF.B 11672 11673, 11675, 11676, 11677, 11678, 11679, 11681, 11686, 11691.

Description: Leaflets narrow to broadly elliptic, sharply simple serrate, secondary venation brochidodromous with additional loops.

Remarks: See below, for Pterocarya.

Pterocarya Kunth

Pterocarya paradisiaca (Unger) Iljinskaya

Fig. 8c

Material: SF.B 11680, 11684, 11690, 11692, 11693. 11696, 11698. 


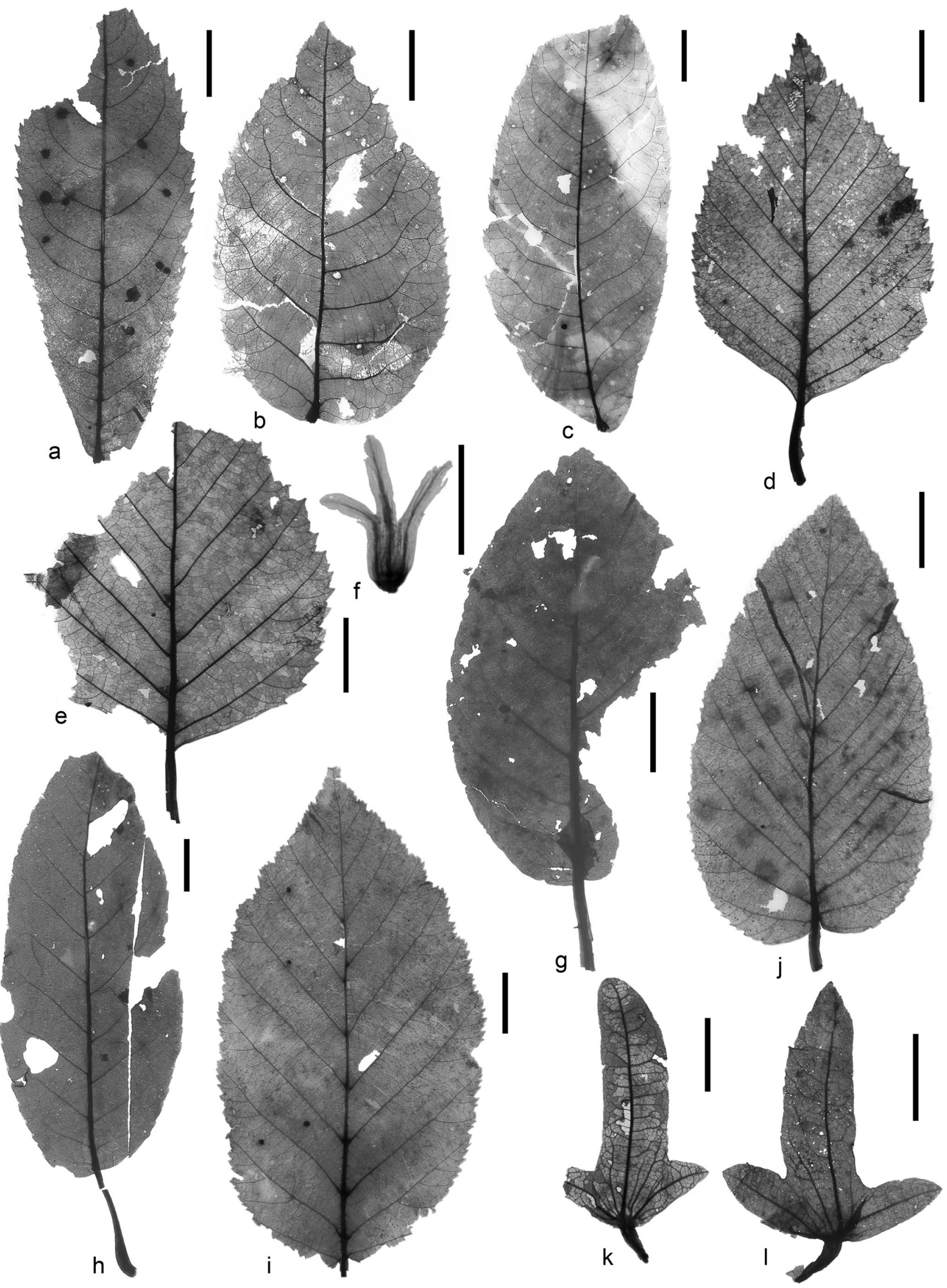


Fig. 8 a Carya sp., incomplete leaflet, SF.B 11690, 10 mm. b Carya sp., complete leaflet, SF.B 11681, $10 \mathrm{~mm}$. c Pterocarya paradisiaca (Unger) Iljinskaya, complete leaflet, SF.B 11623, $10 \mathrm{~mm}$. d Betula similis (Göppert) Zastawniak et Walther, complete leaf, SF.B 11805, $10 \mathrm{~mm}$. e Betula similis (Göppert) Zastawniak et Walther, incomplete leaf, SF.B 11792, 10 mm. f Betula longisquamosa Mädler, fruit, SF.B 11809, $10 \mathrm{~mm}$. g Alnus gaudinii (Heer) Erw. Knobloch et Kvaček, incomplete leaf, SF.B 11762, 10 mm. h Alnus gaudinii (Heer) Erw. Knobloch et Kvaček, complete leaf, SF.B 11760, 10 mm. i Carpinus grandis Unger, complete leaf, SF.B 11754, $10 \mathrm{~mm}$. j Carpinus grandis Unger, complete leaf, SF.B 11734, 10 mm. k Carpinus grandis Unger, fruit, SF.B 11747, $10 \mathrm{~mm}$. I Carpinus grandis Unger, fruit, SF.B 11714, $10 \mathrm{~mm}$

Description: Leaflets asymmetrical, slender at base, bluntly simple serrate, secondary venation brochidodromous.

Remarks: The differences between foliage of Carya, Cyclocarya Iljinskaja and Pterocarya are difficult to establish. A more exact identification requires epidermal details of every specimen (see Kvaček et al. 2008). However, the blunt, simple serrate margin of the leaflets included here indicates that they belong to Pterocarya.

Betulaceae Gray

Betula Linnaeus

Betula similis (Göppert) Zastawniak et Walther

Figs. 8d-f and 171-m

1855 Alnus similis Göppert, p. 13, pl. 4, fig. 5

1998 Betula similis (Göppert) Zastawniak et Walther, p. 103, pl. 4 , fig. 5 , pl. 5 , figs. $1-7$, pl. 6 , figs. $6-8$, text-figs. $2 / 8$, $11-12,3 / 5,8,10 / 1-13,13 / 12-13$

Material: SF.B 11784, 11785, 11787, 11792, 11800, 11805, 11806 (leaves).

Description: Leaves petiolate, lamina ovate, $45-70 \mathrm{~mm}$ long, 23-55 $\mathrm{mm}$ mm wide, base cuneate, apex acute, margin simple, rarely double serrate, teeth eglandular, narrow acute to apiculate, venation craspedodromous, primary vein straight, secondary veins straight, in five to eight pairs, agrophic lateral veins single or several, tertiary veins distinct, epidermal structure (no. SF.B 11806) of adaxial cuticle distinct, ordinary cells straight-walled, $20-50 \mu \mathrm{m}$ in diameter, dispersed simple trichome bases on veins, abaxial cuticle thin, ordinary cells straight-walled, $15-25 \mu \mathrm{m}$ in diameter, stomata anomocytic, of different size, 12-25 $\mu \mathrm{m}$ long, $10-15 \mu \mathrm{m}$ wide, solitary polycellular bases of glands on veins both abaxially and abaxially.

Remarks: Leaves co-occur with fruit bracts of $B$. longisquamosa Mädler (Fig. 8f). As stated by Hummel (1991) the fossil species is similar in epidermal structure to the modern B. platyphylla Sukaczev and corresponds to that described for Betula plioplatyptera Hummel (1991) and B. subpubescens Göppert sensu Hummel (1991) from Ruszów. The epidermal structure is unknown from Göppert's type material from Sośnica (Zastawniak and Walther 1998), but a part of the specimens assigned to Alnus adscendens (Göppert) Zastawniak et Walther from the same site overlaps with Betula similis.
Alnus Miller

Alnus gaudinii (Heer) Erw. Knobloch et Kvaček

Fig. 8g, h

Material: SF.B 11760, 11762.

Description: Leaves long petiolate, petiole up to $20 \mathrm{~mm}$ long, lamina $>80 \mathrm{~mm}$ long, narrow ovate, $30-35 \mathrm{~mm}$ wide, rounded at base, apex not preserved, margin indistinctly serrate, venation semicraspedodromous-craspedodromous, primary vein straight, secondaries regularly spaced, mostly at an angle of $60^{\circ}$, in $7-10$ pairs.

Remarks: Similar alder leaves are known from Oligocene to Pliocene strata of Central Europe. Among these are leaves from the Pliocene of Willershausen referred to as Alnus cf. gaudinii (Heer) Erw. Knobloch et Kvaček (Knobloch 1998, pl. 43, figs. 1-7) and the late Miocene flora of Kodor, Abkhasia (Kolakovskij 1964, as Alnus agustifolia). The nearest living relative for this fossil species is the Caucasian alder, A. subcordata C.A. Meyer that differs from the fossil species by slightly wider leaves.

Carpinus Linnaeus

Carpinus grandis Unger

Fig. $8 \mathrm{i}-1$

1939 Carpinus betulus Linnaeus fossilis Engelhardt et Kinkelin; Mädler, p. 77, pl. 7, figs. 15-16

Material: A few selected most characteristic specimens SF.B 11708, 11709, 11710, 11711, 11732, 11734, 11745, 11748, 11750, 11752, 11753, 11754, 11774, 11776.

Description: Leaves petiolate, lamina elliptic to ovate, finely and sharply double serrate, base cuneate to cordate, apex acute, venation craspedodromous, secondary veins dense, regularly spaced, departing from primary vein at moderate angles. For details, see Mädler (1939).

Remarks: The foliage co-occurs with fruits of the Carpinus betulus type (SF.B 11714, 11718, 11721, 11726, 11747). The nearest living relative is Carpinus betulus Linnaeus distributed in the temperate zone of Europe to Iran.

Carpinus cf. uniserrata (Kolakovskij) Ratiani

Fig. 9a

? 1955 Carpinus cuspidens (Saporta) Kolakovskij var uniserrata Kolakovskij, p. 232, pl. 4, figs. 6-7

? 1964 Carpinus uniserrata (Kolakovskij) Ratiani ex Kolakovslij, p. 65, pl. 19, figs. 7-14

Material: SF.B 11728, 11731.

Description: Leaves short petiolate, blade narrow ovate, more than $60 \mathrm{~mm}$ long, ca. $20 \mathrm{~mm}$ wide, apex long acute, base cuneate, 


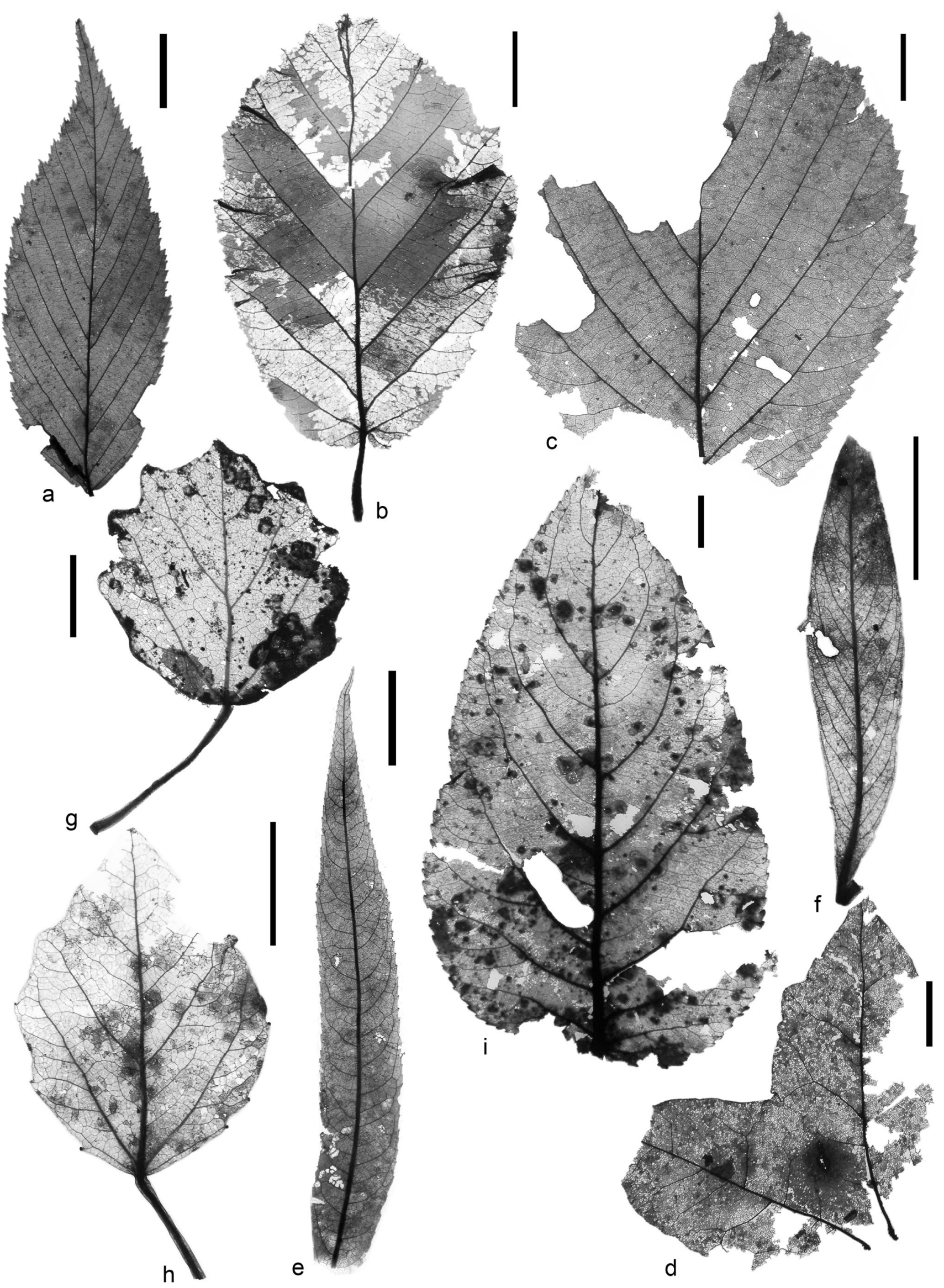


4 Fig. 9 a Carpinus cf. uniserrata (Kolakovskij) Ratiani, complete leaf, SF.B 11731, $10 \mathrm{~mm}$. b Corylus kolakovskyi Budantsev, complete leaf, SF.B 11751, 10 mm. c Corylus kolakovskyi Budantsev, incomplete leaf, SF.B 11757, $10 \mathrm{~mm}$. d Trichosanthes sp., complete leaf, SF.B 12226, $10 \mathrm{~mm}$. e Salix lavateri A. Braun sensu Hantke, incomplete leaf, SF.B 11633, $10 \mathrm{~mm}$. f Salix lavateri A. Braun sensu Hantke, complete leaf, SF.B 11654, 10 mm. g Populus canescentoides Erw. Knobloch, complete leaf, SF.B 11532, $10 \mathrm{~mm}$. h Populus canescentoides Erw. Knobloch, complete leaf, SF.B 11537, 10 mm. i Populus balsamoides Göppert, complete leaf, SF.B 11520, $10 \mathrm{~mm}$

margin sharply double serrate, venation craspedodromous, primary vein straight, secondary veins $>12$ pairs, steep.
Remarks: Knobloch (1998) stated that this type of foliage resembles Ostrya Scop. We agree with Knobloch (1998), who described similar leaf forms from the Pliocene of Willershausen and considered them belonging to the genus Carpinus. The modern hornbeam $C$. caroliniana Walter (syn. C. americanus Michxaux) produces similar but wider and coarsely serrate leaves.

Corylus Linnaeus

Corylus kolakovskyi Budantsev

Fig. 9b, c

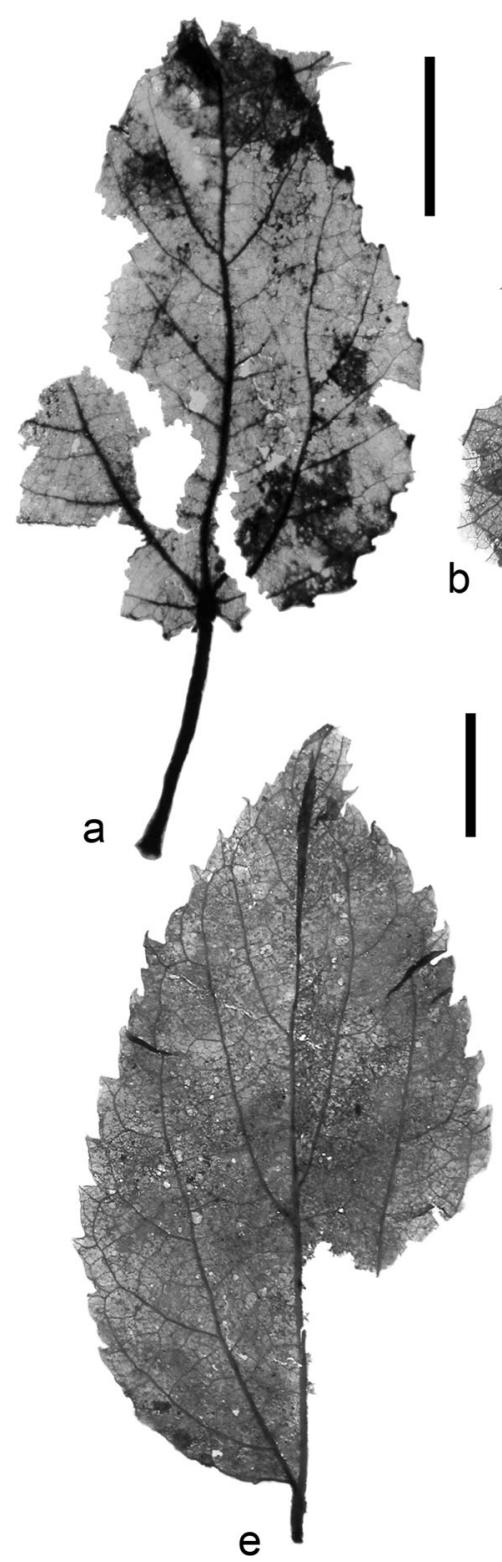

Fig. 10 a Populus gregorii Erw. Knobloch, incomplete leaf, SF.B 11589, $10 \mathrm{~mm}$. b Populus gregorii Erw. Knobloch, fragmentary leaf, SF.B 11591, 10 mm. c Populus populina (Brongniart) Erw. Knobloch, complete leaf, SF.B 11598, 10 mm. d Populus populina (Brongniart) Erw.

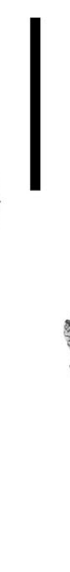

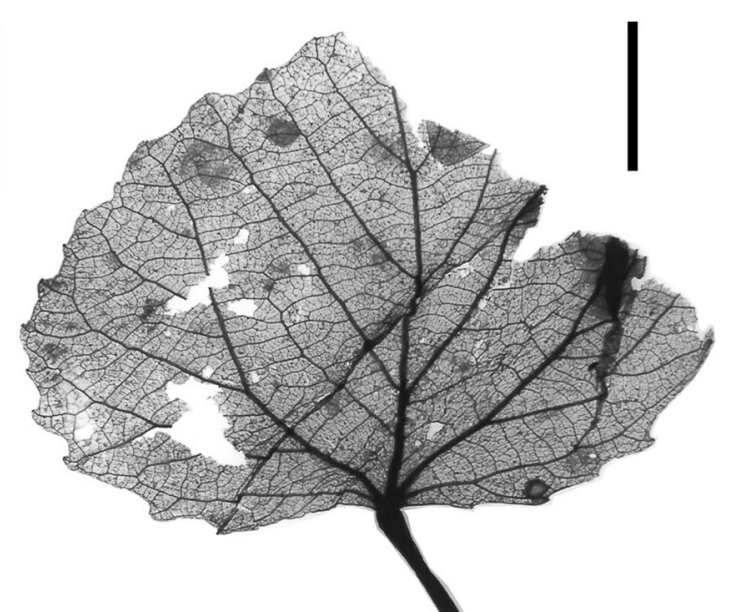
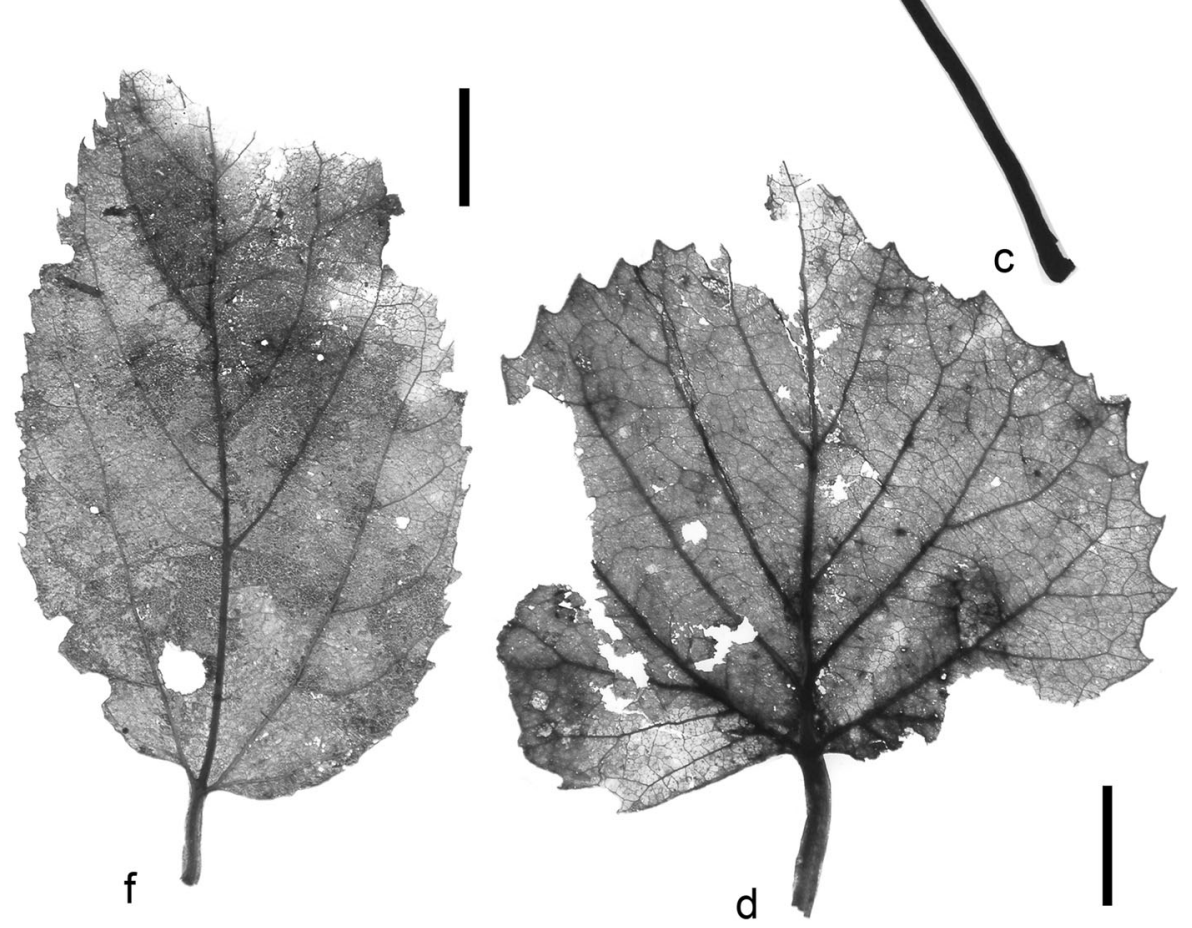

Knobloch, incomplete leaf, SF.B 11551, $10 \mathrm{~mm}$. e Celtis trachytica Ettingshausen, incomplete leaf, SFB. 12125, $10 \mathrm{~mm}$. f Celtis trachytica Ettingshausen, incomplete leaf, SF.B 12118, $10 \mathrm{~mm}$ 
1982 Corylus kolakovskyi Budantsev in Takhtajan, p. 173, pl. 96, figs. 3-4

Material: SF.B 11751, 11755 11757, 11763.

Description: Leaves long petiolate, lamina broadly obovate, up to $60 \mathrm{~mm}$ long, $40 \mathrm{~mm}$ wide, margin finely double serrate, base cordate, apex bluntly cuneate, secondary venation craspedodromous, primary vein straight, secondary veins up to eight pairs, straight, basally numerous abmedial veins, tertiary veins slightly oblique, dense, reticulate.

Remarks: The original material of Corylus kolakovskyi was described from the Pliocene of Duab and compared with C. avellana (Kolakovskij 1952). According to Budantsev (in Takhtajan 1982), foliage of this fossil species is morphologically more similar to the living Corylus maxima Miller due to a less prominently lobed margin. The same leaf morphotype was determined as Corylus avellana Linnaeus fossilis from the Pliocene of Willershausen (Knobloch 1998, p. 43, pl. 5 fig. 10, pl. 19, figs. $2-3$, pl. 22, fig. 10 , pl. 23 , fig. 4 , pl. 25, figs. $1-2,5$ ).

Cucurbitaceae Jussieu

Trichosanthes Linnaeus

Trichosanthes sp.

Figs. 9d and $17 \mathrm{n}$

? 1939 Magnolia moenana Mädler, p. 96, pl. 1, figs. 7-8, textfig. 29

? 1939 Acer palaeo-miyabei Mädler, p. 117, pro parte, pl. 9, fig. 17

? 1939 Acer integerrimum Viviani sensu Mädler, p. 118, pro parte, pl. 9, fig. 18

2008 Trichosanthes sp.; Kvaček, Teodoridis and Gregor, p. 31 , pl. 9, figs. $13-16$, pl. 10, figs. 1-3, pl. 20, figs. 12-14

Material: SF.B 12191, 12226, cuticle preparations SF.B 12191.1-2.

Description: Leaves trilobate (to pentalobate), lobes entiremargined. Fragments of adaxial cuticle revealing thin, straight-walled unspecialised cells; the structure of the abaxial cuticle not well discernible, thin cuticle on its surface crenulate-striate, showing indistinct, tiny, rounded stomata 10 $15 \mu \mathrm{m}$ in diameter, thick-walled simple trichomes 120 $380 \mu \mathrm{m}$ long with bulbous base $35-45 \mu \mathrm{m}$ in diameter, distributed across the abaxial leaf surface.

Remarks: Mädler (1939) described similar massive trichomes on a leaf fragment, which he interpreted as serial trichomes. He considered the fragment to belong to Magnolia. Similar hairy leaf fossils have previously been recovered from Pliocene deposits of Auenheim and were identified as Trichosanthes (Kvaček et al. 2008).

Salicaceae Mirbel

Salix Linnaeus
Salix lavateri A. Braun sensu Hantke

Fig. 9e, f

1851 Salix lavateri A. Braun, p. 78

1908 Salix denticulata Heer; Engelhardt and Kinkelin, p. 228, pl. 28, figs. 2a, b (? Non "Knospenschuppen" 3-4)

1939 Salix denticulata Heer; Mädler, p. 52, pl. 5, fig. 15 (? non fruits 16-17)

1954 Salix lavateri A. Braun; Hantke, p. 55, pl. 5, figs. 2-16

Material: Only newly recovered leaves; SF.B 11602, 11604, 11609, 11619, 11616, 11623, 11633, 11635, 11637, 11645, 11646, 11649, 11651, 11652, 11656, 11654 (cf.), cuticle preparations SF.B 11623.1-3.

Description: Adaxial cuticle smooth, on veins slightly striate, unspecialised cells polygonal, straight-walled, ca. 25-35 $\mu \mathrm{m}$ in diameter, solitary brachyparacytic stomata and simple rounded trihome bases near margin; abaxial cuticle smooth, at places slightly striate, anticlinal walls of unspecialised cells rarely seen, straight, stomata brachyparacytic, guard cell pairs narrow elliptic, uniformly sized, 15-20 $\mu \mathrm{m}$ long, $10 \mu \mathrm{m}$ wide, solitary simple trichome bases.

Remarks: The new material belongs to the same morphotype as described by Mädler (1939, as Salix denticulata). The single leaf epidermis studied matches only a part of the material of Salix from Auenheim, namely the specimens that almost lack the wax cover abaxially (Kvaček et al. 2008, p. 32, as Salix sp.).

Populus Linnaeus

Populus balsamoides Göppert

Figs. 9i and 18d, e

1855 Populus balsamoides Göppert, p. 23, pl. 15, figs. 5-6

1939 ? Populus sp. cf. nigra L.; Mädler, p. 52, pl. 5, figs. 18-19

Material: Numerous newly recovered compressions in glass preparations, $>15$ leaves including fragments; selected specimens SF.B 11508, 11509, 11511, 11515, 11520, 11524, 11525, 11526, cuticle preparations SF.B 11670.1-2.

Description: Leaves long petiolate, lamina ovate, margin glandular crenulate. A single leaf compression yielded only cuticle of the abaxial side, cuticle very thin, fragmentary, unspecialised cells with curved anticlinal walls, stomata brachyparacytic, guard cell pairs elliptic, 17-25 $\mu \mathrm{m}$ long, 12-15 $\mu \mathrm{m}$ wide, ledges slightly thickened, reaching almost to poles, pore narrow to widely spindle-shaped, solitary trichome bases simple rounded, on veins.

Remarks: The cuticle structure matches the material described from the Pliocene of Auenheim and identified as Populus cf. balsamoides (Kvaček et al. 2008). This very common fossil poplar species requires revision of the type material from the late Miocene site Sośnica. Iljinskaja (2005) suggested close similarities of this 
fossil species with the modern $P$. tibetica Thomson ex Kam.

Populus populina (Brongniart) Erw. Knobloch

Fig. 10c, d

1822 Phyllites populina Brongniart, p. 237, pl. 14, fig. 4 1964 Populus populina (Brongniart) Erw. Knobloch, p. 601 1988 Populus populina (Brongniart) Erw. Knobloch, p. 16, pl. 9 , figs. 2,6 , pl. 13 , figs. $6-8$

Material: SF.B 11531, 11535, 11536, 11545, 11550, 11551, $11552,11553,11554,11555,11556,11557,11560,11563$, $11564,11565,11566,11568,11569,11571,11572,11573$, $11581,11554,11555,11556,11557,11553,11552,11564$, $11571,11560,11568,11569,11563,11566,11580,11581$, 11598, 11600, 11601.

Description: See Knobloch (1964, 1988).

Remarks: The above listed specimens include morphotypes matching the type specimen of Brongniart's Phyllites populina. The cuticle structure of specimens was not accessible.

Populus gregorii Erw. Knobloch

Fig. 10a, b

1998 Populus gregorii Erw. Knobloch, p. 52, pl. 27, figs. 1-4, 6, text-fig. 18

Material: SF.B 11587, 11589, 11591, 11592, 11595, 11597. Description: Leaves long petiolate, lamina ovate, margin from the base upwards bluntly and regularly dentate.

Remarks: Similar morphotypes have been assigned to Populus tremula pliocenica Saporta from the Pliocene locality of Reuver (Laurent and Marty 1923, p. 13, pl. 2, figs. 4-9).

Populus canescentoides Erw. Knobloch

Fig. 9g, h

1998 Populus canescentoides Erw. Knobloch, p. 51, pl. 27, figs. 5,7 , pl. 29 , figs. 7,9

Material: SF.B 11530, 11532, 11534, 11537, 11538, 11539, 11542 , 11543, 11544, 11546, 11547, 11548, 11549, 11558, 11567, 11578, 11593.

Description: Leaves long petiolate, lamina broadly ovate to narrow ovate, in upper part shallowly widely lobate.

Remarks: This morphotype is similar in leaf shape and margin to the Pliocene population from Reuver (Laurent and Marty 1923, p. 13, pl. 3, figs. 3, 5-6 assigned to Populus alba pliocenica).

Cannabaceae Martinov

Celtis Linnaeus
Celtis trachytica Ettingshausen

Fig. 10e, f

1853 Celtis trachytica Ettingshausen, p. 801, pl. 1, fig. 7

Material: SF.B 11562, 12115, 12118, 12124, 12125.

Description: Leaf short petiolate, petiole 5-8 $\mathrm{mm}$ long, lamina 45 to $>80 \mathrm{~mm}$ long, $20-40 \mathrm{~mm}$ wide, base rounded to acute, slightly asymmetric, margin sparsely toothed, venation triveined, primary vein and two lateral veins originating from leaf base, lateral veins similar to secondary veins, secondary venation brochidodromous, departing in a steep angle from primary vein, bent, additional loops formed by abmedial veins, small side veins from secondary and abmedial veins entering the fine teeth, tertiary veins perpendicular to secondary veins, percurrent or branched.

Remarks: Kutuzkina (in Takhtajan 1982) considered this fossil species with rounded leaf base and typical of the late Miocene of Europe as distinct from $C$. japeti Unger, which is more common in middle Miocene strata.

Sapindaceae Jussieu

Acer Linnaeus

Acer dombeyopsis Kvaček, Teodoridis et Denk sp. nov.

Figs. 11a, b and 18f, g

Material: SF.B 12186, 12202, 12204, 12211, 12220, 12237, 12238, 12270, cuticle preparations SF.B 12211.1-3.

Holotype selected here: SF.B 12211 (fig. 11a), cuticle preparation SF. B 12211.1.

Derivatio nominis: Referring to the leaf morphological similarity with the fossil genus Dombeyopsis Unger.

Description: Leaves palmately shallowly trilobed, entiremargined (or rarely with a few sharp teeth on lobes). Areoles without free-ending veinlets (sample SF.B. 12211); adaxial cuticle smooth, thin, reflecting wavy anticlines of ordinary cells, ordinary cells $20-50 \mu \mathrm{m}$ in diameter, abaxial cuticle thin, ordinary cells ca. $20 \mu \mathrm{m}$ in diameter, stomata rounded, anomocytic (to cyclocytic), 20-25 $\mu \mathrm{m}$ in diameter, stomatal ledges broad, pore short, $10 \mu \mathrm{m}$ long, simple trichomes 150-200 $\mu \mathrm{m}$ long very sparsely dispersed over the whole abaxial surface.

Remarks: Acer dombeyopsis imitates in its leaf anatomy and morphology some Hamamelidaceae (Disanthus, Mytillaria), but stomata are anomocytic and the general features of epidermal anatomy correspond to Acer. In its leaf morphology, A. dombeyopsis corresponds to A. paxii Franchet and A. buergerianum Miquel of the section Pentaphylla $\mathrm{Hu}$ et Cheng native in mountains of Yunnan and to A. sterculiaceum Wallich (Himalayas to East Asia) in the sect. Lithocarpa Pax (van Gelderen et al. 1994). A fragment of the same species showing similar epidermal patterns was described as Acer integerrimum (Viviani) Massalongo by Kvaček et al. (2008), p. 25, pl. 7, figs. 12-13, pl. 19, figs. 11-12) from the Pliocene flora of Auenheim. 


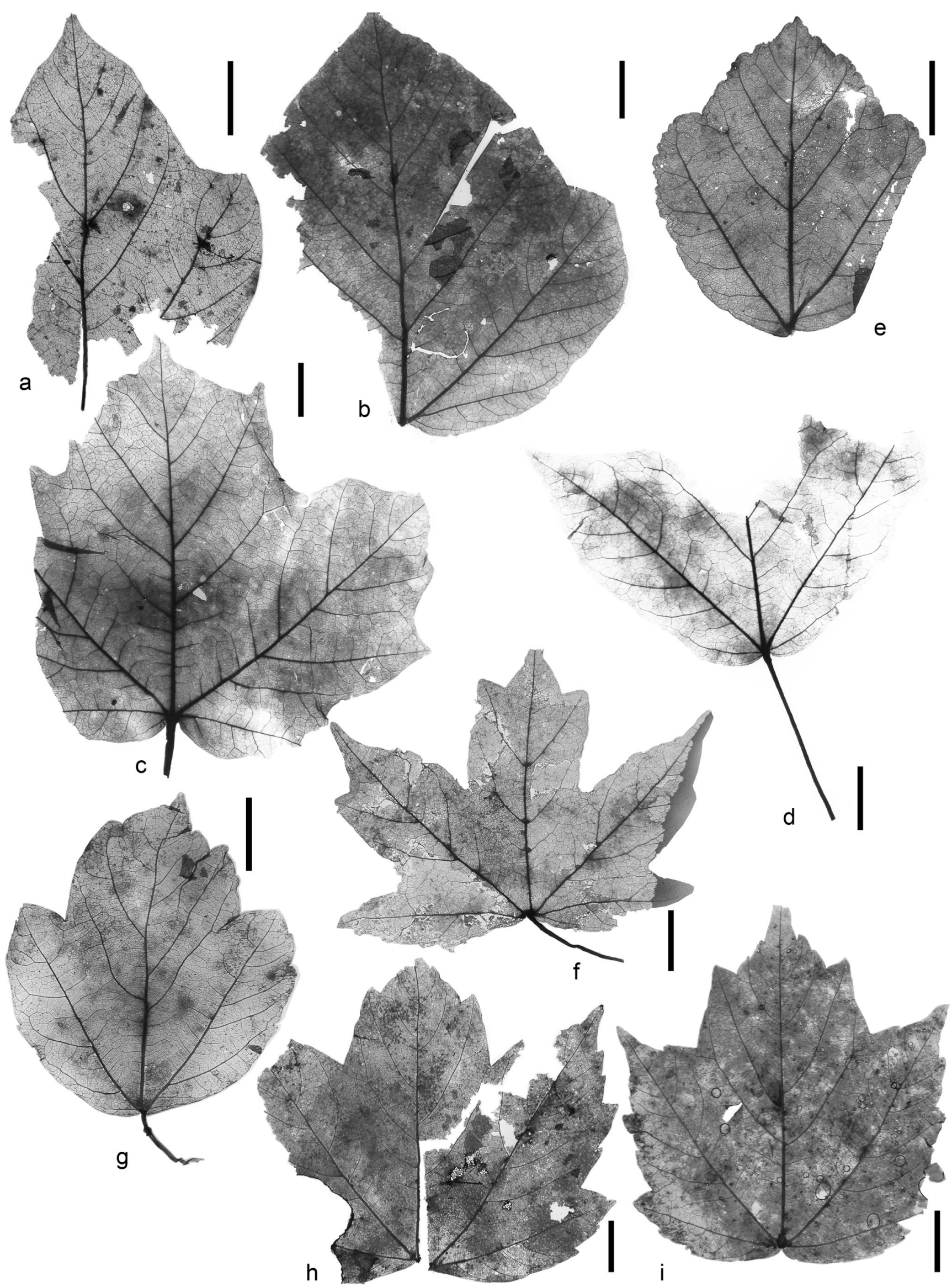


Fig. 11 a Acer dombeyopsis Kvaček, Teodoridis et Denk sp. nov., incomplete leaf, SF.B 12211, 10 mm. b Acer dombeyopsis Kvaček, Teodoridis et Denk sp. nov., incomplete leaf, SF.B 12270, $10 \mathrm{~mm}$. c Acer aff. platanoides Linneaus, incomplete leaf, SF.B 12234, $10 \mathrm{~mm}$. d Acer integerrimum (Viviani) Massalongo, incomplete leaf, SF.B 12243, $10 \mathrm{~mm}$. e Acer pyrenaicum Rérolle, complete leaf, SF. B 12352, $10 \mathrm{~mm}$. f Acer subcampestre Göppert, complete leaf, SF.B 12324, 10 mm. g Acer viburnoides Kvaček, Teodoridis et Denk sp. nov., complete leaf, SF.B 12210, 10 mm. h Acer vitiforme Kvaček, Teodoridis et Denk sp. nov., complete leaf, SF.B 12247, 10 mm. i Acer vitiforme Kvaček, Teodoridis et Denk sp. nov., complete leaf, holotype SF.B 12183, $10 \mathrm{~mm}$

Acer aff. platanoides Linnaeus

Figs. 11c and 18k, 1

Material: SF.B 12219, B12234, cuticle preparations SF.B 12219.1-2.

Description: Leaves simple, long petiolate, lamina palmately pentalobate; adaxial cuticle smooth to faintly striate, unspecialised cells $35-50$ um in diameter, anticlinal walls strongly zick-zack undulate; abaxial cuticle non-papillate, thin, smooth, strong trichomes on veins, stomata anomocytic, broadly elliptic to rounded, ca. $22 \mu \mathrm{m}$ in diameter, stomatal ledges slightly thickened, pore broadly elliptic, simple trichomes $\geq 120 \mu \mathrm{m}$ long, dispersed on veins.

Remarks: The examined pentalobate maple leaf compressions correspond in gross morphology as well as epidermal anatomy (SF.B 12219) to the modern Acer platanoides L. (Europe-Caucasus) and Acer miyabei Maximowicz (northern Japan), Acer sect. Platanoidea Pax. They differ from the fossil A. protomiyabei Endo (Miocene of Japan, Tanai 1983) by wider lobes. The epidermal anatomy of the latter is not known. Fossils with close relationships to the extant A. platanoides have only rarely been recorded in the fossil state. Fruits comparable with A. platanoides have been described from the Pliocene of Frankfurt/M. by Mädler (1939) as A. platanoides Linnaeus fossilis. For morphological comparisons of similar fossils from Asia, see Wolfe and Tanai (1987, pl. 61) and Tanai (1983), p. 301, 334, pl. 8, figs. 1, 3, text-fig. 3.28).

\section{Acer pyrenaicum Rérolle}

Fig. 11e

1884-1885 Acer pyrenaicum Rérolle, p. 386, pl. 12, figs. 2-6

Material: SF.B 12352, 12356, 12357, 12358, 12359, 12360. Description: Leaves simple, broadly ovate to rarely sub-trilobate, long petiolate, petiole dilatated at base, $25-32 \mathrm{~mm}$ long, lamina 43-65 mm long, 38-55 mm wide, margin double crenate to bluntly dentate in upper two thirds, apex rounded to acute or rarely shortly acuminate, partly with two rounded lobes, base rounded to shallow cordate, venation palmate, craspedodromous to semicraspedodromous, three primary veins, exceptionally five, primary vein stout, lateral primary and lower secondary veins departing at angles of $30-35^{\circ}$, higher secondary veins departing at wider angles, curved into marginal teeth, intersecondary veins rare, epimedial tertiary veins alternate percurrent, exterior tertiary veins variable.

Remarks: The foliage compressions assigned to A. pyrenaicum are variable in leaf shape from broadly elliptic to sub-trilobate, but quite characteristic in the dentition and venation patterns. Similar leaf fossils were rarely noted, partly together with fruits of the Acer tataricum type in the European Pliocene, e.g. at Lozenetz (Palamarev and Kitanov 1988, pl. 10, fig. 5, as Acer tricuspidatum A.Br. ex Agass. forma productum (A. Braun) Procházka et Bůžek) and Gurmen (Palamarev and Kitanov 1977, p. 17, text-fig. 1, as Acer tataricum Linnaeus fossilis) in Bulgaria (see Palamarev et al. 2005, p. 241). Similar morphotypes but differing in mostly broader sub-trilobate leaf lamina have been assigned to Acer pyrenaicum Rérolle from late Neogene sites in southern Europe (see Kvaček et al. 2002, p. 86). The epidermal structure obtained from morphologically similar leaf compressions from the Pliocene of Auenheim (Kvaček et al. 2008, as Acer cf. tricuspidatum Bronn forma productum (A. Braun) Procházka et Bǔžek) deviates from the common epidermal structure of Acer tricuspidatum, which shows dense and thick-walled trichomes (cf. Walther 1972). The modern Acer tataricum Linnaeus subsp. tataricum of section Ginnala Nakai distributed in Eastern Europe to Caucasus and Turkey resembles this fossil species in leaf architecture. Typical foliage of Acer tataricum differs distinctly by the acuminate apex and the elongate elliptic form of the lamina. Since the fossil leaves are not preserved in physical connection with fruits, the affinities with modern maples are difficult to establish. Some more modern species (e.g. A. pycnanthum K. Koch from Japan or a doubtful hybrid A. x schwerinii Pax) may also produce similar foliage.

Acer subcampestre Göppert

Figs. 11f and 18h, i

1855 Acer subcampestre Göppert, p. 34, pl. 22, figs. 16-17

Material: SF.B 12198, 12209, 12213, 12324, cuticle preparations SF.B 12324.1-3.

Description: Leaves palmately tri- to pentalobate, petiolate, lamina chartaceous, $45-55 \mathrm{~mm}$ long, $60-80 \mathrm{~mm}$ wide, lobes acute, 16 to $30 \mathrm{~mm}$ wide, apically with shallow blunt teeth, basally shallow cordate, petiole thin, $>20 \mathrm{~mm}$ long, usually not preserved, venation palmate, three primary veins, straight craspedodromous, secondary veins and solitary intersecondaries semicraspedodromous, epimedial tertiaries mixed, areoles mostly without free-ending veinlets. Cuticles (investigated in SF.B 12324) extremely thin. Adaxial cuticle smooth to fine striate, ordinary cells polygonal, $25 \mu \mathrm{m}$ in diameter; abaxial cuticle with straight-walled ordinary cells on veins, ca. $8 \mu \mathrm{m}$ wide, $25 \mu \mathrm{m}$ 


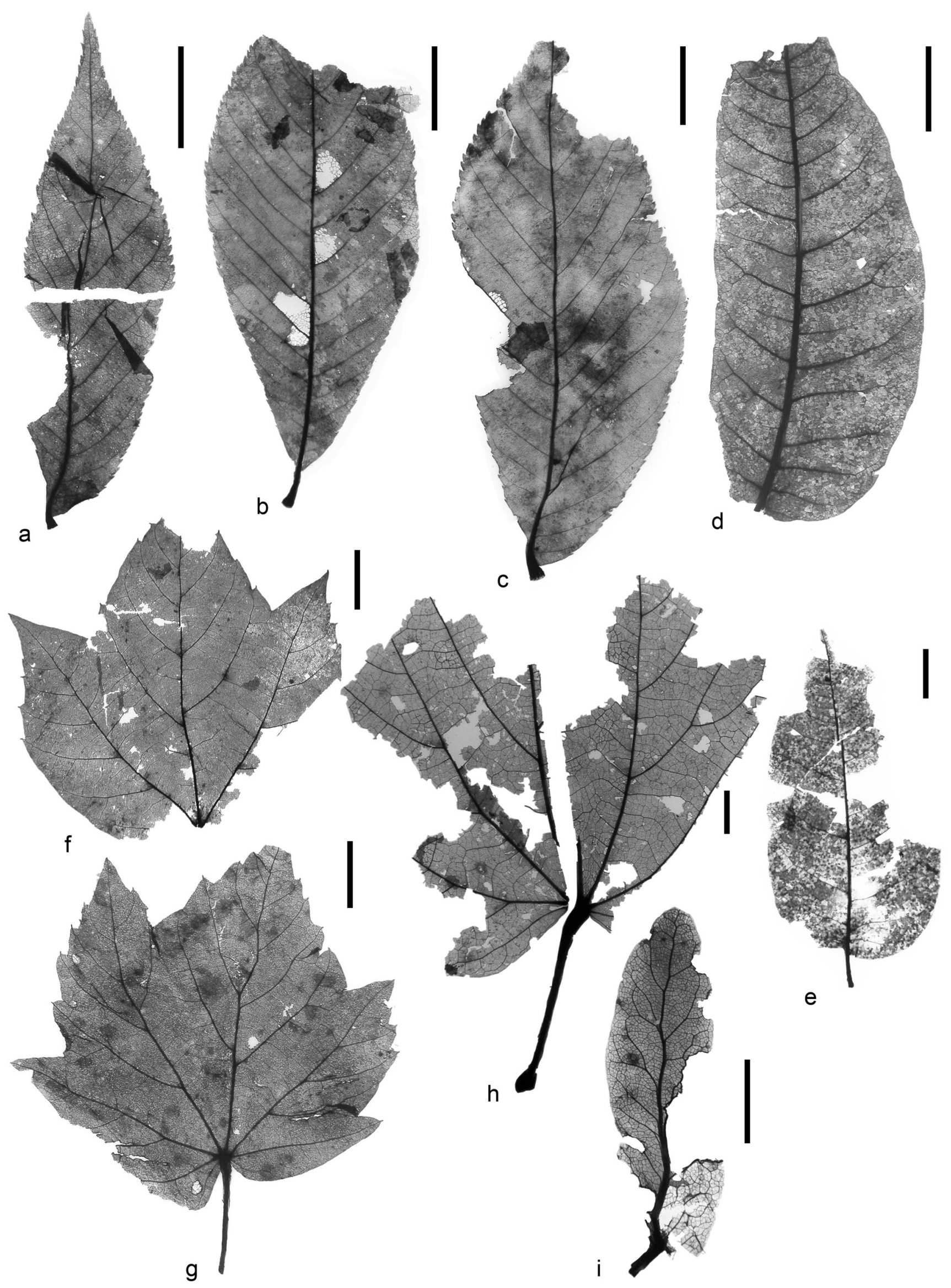


Fig. 12 a Aesculus hippocastanoides Iljinskaja, complete leaflet, SF.B 12390, $10 \mathrm{~mm}$. b Aesculus hippocastanoides Iljinskaja, incomplete leaflet, SF.B 12392, $10 \mathrm{~mm}$. c Aesculus hippocastanoides Iljinskaja, complete leaflet, SF.B 12391, $10 \mathrm{~mm}$. d "Juglans" acuminata A. Braun, incomplete leaflet, SF.B 11668, $10 \mathrm{~mm}$. e "Juglans" acuminata A. Braun, complete leaflet, SF.B 11665, $10 \mathrm{~mm}$. f Hibiscus sp., complete leaf, SF.B 12263, $10 \mathrm{~mm}$. g Hibiscus sp., complete leaf, SF.B 12347, $10 \mathrm{~mm}$. h aff. Dombeyopsis lobata Unger, complete leaf, SF.B 12194, $10 \mathrm{~mm}$. i ? Tilia sp., isolated bracts, SF.B 12386, $10 \mathrm{~mm}$

long; stomata anomocytic, elliptic to narrow elliptic, of different sizes, mostly $12 \mu \mathrm{m}$ long and 7-10 $\mu \mathrm{m}$ wide, rarely larger, up to $28 \mu \mathrm{m}$ long and $18 \mu \mathrm{m}$ wide, stomatal ledges thin, forming short elliptic outer cavity, pore linear. Single peltate glands with polycellular heads on veinlets, solitary simple unicellular trichomes on thicker veins, no papillae observed.

Remarks: The leaf morphology of this fossil species is variable, as seen in the newly described type material of Sośnica (Walther and Zastawniak 2005) and in various late Miocene and Pliocene localities in Europe (Ströbitzer-Hermann and Kovar-Eder 2003). Leaf epidermal features of this species are here reported for the first time. Acer subcampestre is characterised by its very delicate cuticle, which is well distinguishable from the much tougher cuticles of Acer tricuspidatum Bronn, which is densely hairy on the abaxial leaf side (Walther 1972), and from similar maple species of sect. Acer with papillate abaxial cuticles. Among extant species of sect. Platanoidea, A. campestre L. has similarly arranged ordinary cells and stomata and differs in having few thick-walled simple non-glandular trichomes with thick finely granulate walls and polycellular glandular peltate trichomes, ca. $50 \mu \mathrm{m}$ in diameter, on bi-triserial stalks.

\section{Acer integerrimum (Viviani) Massalongo}

Figs. 11d and 20i, j

1833 Acerites integerrima Viviani, p. 131, pl. 11, fig. 6

1859 Acer integerrimum (Viviani) Massalongo; Massalongo and Scarabelli, p. 341, pl. 18, fig. 3

Material: SF.B 12243, 12298, cuticle preparation SF.B 12243.1.

Description: Leaf long petiolate, petiole $28 \mathrm{~mm}$ long, lamina preserved only in lower part, trilobate (?), shallow cordate, entiremargined, the preserved lobe acute. Adaxial cuticle reflecting unspecialised polygonal cells with straight to wavy anticlines, 25-35 $\mu \mathrm{m}$ in diameter; abaxial cuticle fragmentary, smooth showing anomocytic stomata irregularly orientated, rounded to broadly elliptic 15-20 (-26) $\mu \mathrm{m}$ with wide pore limited by thick stomatal ledges not reaching to the poles, simple smooth thinwalled trichomes $10 \mu \mathrm{m}$ thick and up to $130 \mu \mathrm{m}$ irregularly and sparsely distributed on the abaxial cuticle.

Remarks: Similar trilobate leaf forms of this maple species occur in the Miocene of Europe (e.g. in Senigaglia, Italy,
Massalongo in Massalongo and Scarabelli 1859, in the Most Basin, Procházka and Bůžek 1975, Kvaček et al. 2004, p. 131, fig. b), but usually with acuminate lobes. The cuticle structure is commonly not preserved because of its delicate nature.

Acer viburnoides Kvaček, Teodoridis et Denk sp. nov.

Figs. $11 \mathrm{~g}$ and $18 \mathrm{j}$

1939 Acer brachyphyllum Heer; Mädler, p. 114, pl. 9, figs. 9-10

Material: SF.B 12210, cuticle preparations SF.B 12210.1-4. Holotype here selected: Leaf compression between glass slides SF.B 12210 (fig. 11g).

Derivatio nominis: The species epithet refers to the resemblance of the leaf with Viburnum opulus L.

Description: Leaf simple, petiolate, petiole thin, lamina chartaceous, shallowly trilobate, apex broadly acute, margin shallowly bluntly simple dentate-lobed, venation basal actinodromous, midrib thin, only slightly thicker than secondaries, basal veins departing at an angle of $40^{\circ}$, higher secondary veins subparallel and widely irregularly spaced, simple, looping and curved along margin, tertiary veins irregularly reticulate. Adaxial and abaxial cuticles thin, adaxial cuticle faintly striate, unspecialised cells irregularly polygonal, 25$50 \mu \mathrm{m}$ in diameter, with curved anticlinal walls, abaxial cuticle densely finely papillate, papillae granular, ca. $8 \mu \mathrm{m}$ in diameter, papillae larger towards leaf margin, densely distributed on stomatal areas, forming rings around hardly visible elliptic stomata, stomata $15 \mu \mathrm{m}$ long and $10 \mu \mathrm{m}$ wide.

Remarks: The leaf compression corresponds in leaf morphology to Acer and Viburnum. Acer obtusifolium Sibthorp et Smith (eastern Turkey, Syria, and Lebanon), Acer sect. Acer is closely similar to the fossil species in leaf epidermal characteristics (Grimm et al. 2007) and in overall leaf shape but differs from the fossil species in its sub-entire margin. The previously applied species name Acer brachyphyllum Heer (Mädler 1939, p. 114, pl. 9, figs. 9-10) is reserved for specimens that belong morphologically to A. tricuspidatum Bronn f. brachyphyllum (Heer) Procházka et Bůžek (1975, p. 28), although epidermal characters of the type specimens from the Sarmatian of Öhningen are not available. Viburnum opulus var. opulus and a closely related American species V. trilobum Marshall, often considered as V. opulus var. americanum Aiton imitate Acer in leaf morphology but clearly differ in epidermal anatomy (non-papillate, striate abaxial cuticle, a different kind of anomocytic stomata).

Acer vitiforme Kvaček, Teodoridis et Denk sp. nov. Figs. 11h, i and 18m, n

Holotype: SF.B 12183 (fig. 11i), cuticle preparation SF.B 12183.1 . 


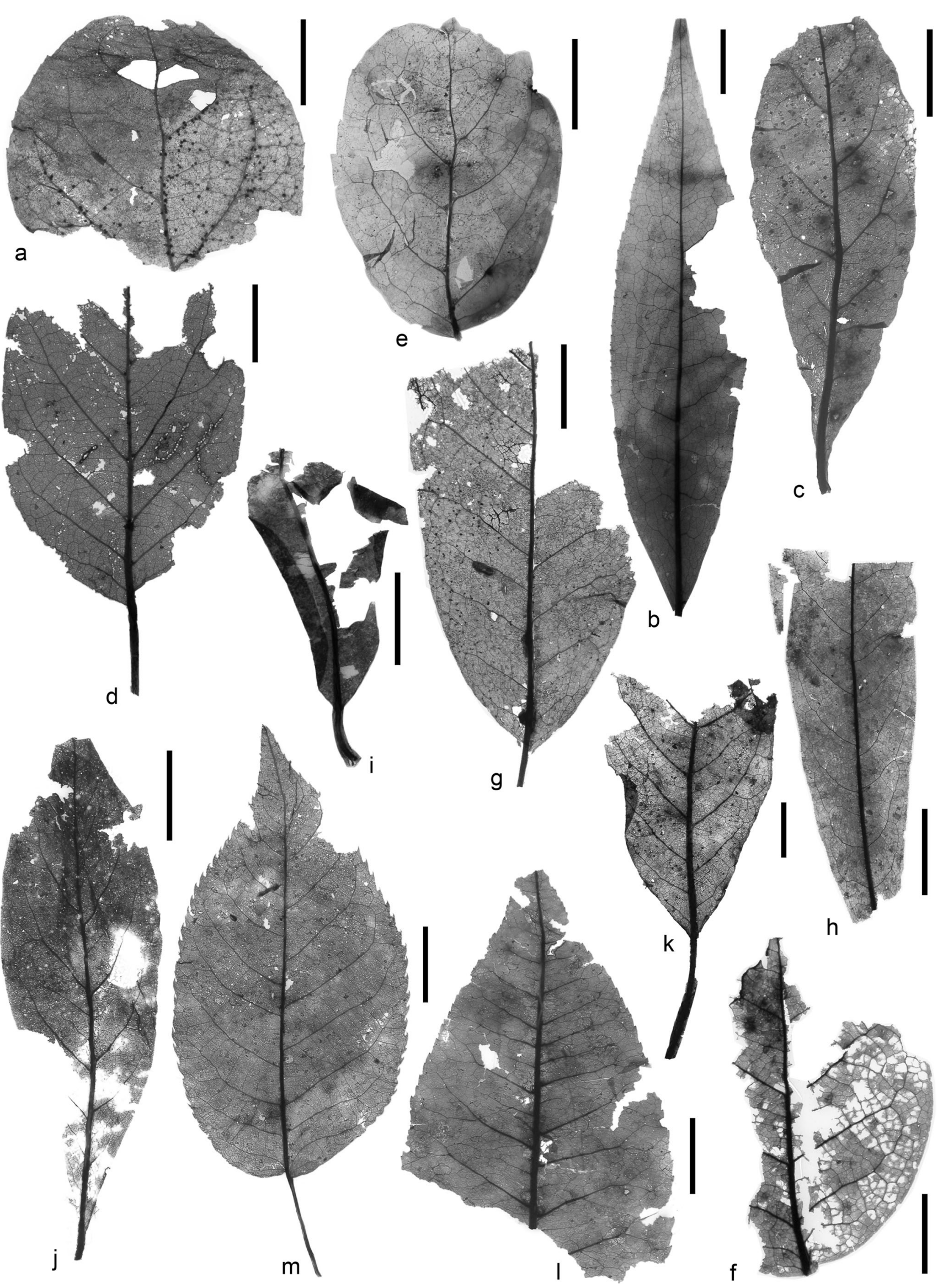


Fig. 13 a Dicotylophyllum sp. C, incomplete leaf, SF.B 12433, $10 \mathrm{~mm}$. b Dicotylophyllum sp. D, complete leaf, SF.B 12440, $10 \mathrm{~mm}$. c Dicotylophyllum sp. E, complete leaf, SF.B 12434, $10 \mathrm{~mm}$. d Dicotylophyllum sp. F., incomplete leaf, SF.B 12435, $10 \mathrm{~mm}$. e Dicotylophyllum sp. G, complete leaf, SF.B 12441, $10 \mathrm{~mm}$. f Dicotylophyllum sp. H, leaf fragment, SF.B 12442, $10 \mathrm{~mm}$. g Dicotylophyllum sp. I, leaf fragment, SF.B 12433, $10 \mathrm{~mm}$. h Dicotylophyllum sp. J, leaf fragment, SF.B 12431, $10 \mathrm{~mm}$. i Dicotylophyllum sp. K, leaf fragment, SF.B 12430, $10 \mathrm{~mm}$. j Dicotylophyllum sp. L, incomplete leaf, SF.B 12437, $10 \mathrm{~mm}$. k Dicotylophyllum sp. M, leaf fragment, SF.B 12156, $10 \mathrm{~mm}$. I Dicotylophyllum sp. N, incomplete leaf, SF.B 12176, $10 \mathrm{~mm}$. m Dicotylophyllum sp. O, complete leaf, SF.B 12180, $10 \mathrm{~mm}$

Paratype: SF.B 12319, cuticle preparations SF.B 12319.1-4. Other material: SF.B 12262, 12247, 12256, 12289, 12294, 12330 .

Derivatio nominis: Referring to the morphological similarity of foliage in Acer and Vitaceae.

Diagnosis: Leaves simple, long petiolate, lamina broadly ovate, trilobate to shortly pentalobate, coarsely dentate, subcordate, slightly asymmetrical, adaxial cuticle faintly striate, ordinary cells polygonal, anticlinal walls straight to slightly bent, abaxial cuticle distinctly fine papillate, stomata cyclocytic, surrounded by a ring of papillae.

Remarks: Foliage of this fossil maple morphologically resembles Vitis but the epidermal structure places it into Acer sect. Acer near the modern A. trautvetteri Medwedew living in the northern Turkey and the Caucasus (cf. Grimm et al. 2007).

Aesculus Linnaeus

Aesculus hippocastanoides Iljinskaja

Fig. $12 \mathrm{a}-\mathrm{c}$

1968 Aesculus hippocastanoides Iljinskaja, p. 79, pl. 24, fig. 8, pl. 27, figs. 1-3, pl. 28, figs. 4-6, pl. 29, fig. 8, pl. 36, figs. 2-3

Material: SF.B 12342, 12390, 12391, 12392.

Description: Leaflets short petiolulate, petiolule broadened at point of attachment, $5 \mathrm{~mm}$ long; lamina obovate, ca. $50 \mathrm{~mm}$ long and $24 \mathrm{~mm}$ wide, incomplete at apices, base cuneate, simple dentate, teeth regularly closely spaced, falcate, venation semicraspedodromous, primary vein thick and straight, secondary veins dense, straight, bent near margin, sending minute outer veinlets into teeth, tertiary veins mixed percurrent (sample SF.B 12392). Adaxial cuticle smooth, straight-walled, abaxial cuticle finely papillate, stomata rarely preserved, anomocytic, rounded.

Remarks: The material shows affinities to the North American members of sect. Pavia (Mill.) Persoon based on the long petiolulate leaflets and epidermal anatomy. The leaves were probably produced by the same species as the fruit and seed fragments described from the same site by Engelhardt (in Engelhardt and Kinkelin 1908). Similar leaflets were described from the
Pliocene of Willershausen (Straus 1930, as Aesculus cf. pavia Linnaeus, Knobloch 1998, as A. velitzelosii Erw. Knobloch). Some other records of Aesculus foliage not preserved with leaf anatomy (Iljinskaja 1968, as A. hippocastanoides Iljinskaja, Walther in Mai and Walther 1988, as A. cf. hippocastanum Linnaeus, Grímsson et al. 2007, as Aesculus sp.) match well in petiolulate leaflets, differing from the modern European A. hippocastanum with sessile leaflets.

Meliaceae Jussieu

"Juglans" acuminata A. Braun

Figs. 12d, e and 19c-f

1845 Juglans (? Carya) acuminata A. Braun, p. 170, nom. nud.

1850 Juglans acuminata A. Braun; Unger, p. 468

1994 Cedrela acuminata (A. Braun) Iljinskaja, p. 76

Material: SF.B 11664, 11665, 11666, 11667, 11668.

Description: Leaflets shortly petiolulate, petiolule max. $5 \mathrm{~mm}$ long, lamina entire-margined, asymmetrically ovate to oblong, up to $>100 \mathrm{~mm}$ long, 24-32 (-45) mm wide, apex acuminate, base truncate, rounded to widely cuneate, venation brochidodromous, primary vein thick, slightly curved, secondary veins in more than 13 pairs, secondary veins alternate to sub-opposite, slightly s-shaped, more closely spaced towards apex, slightly curved, looping near margin, single intersecondary veins commonly present, tertiary veins alternate percurrent, quaternary veins regular reticulate. Epidermal anatomy (sample 11668), adaxial cuticle faintly striate, reflecting polygonal outlines of straight-walled ordinary cells $20-25 \mu \mathrm{m}$ in diameter, anticlinal walls straight, solitary trichome bases simple, rounded, $12 \mu \mathrm{m}$ in diameter, abaxial cuticle irregularly finely striate, rarely with preserved rounded to elliptic head up to $120 \mu \mathrm{m}$ long and $70 \mu \mathrm{m}$ wide, cell outlines not observable, stomata elliptic, anomocytic, all of the same size, 15$20 \times 12 \mu \mathrm{m}$, stomatal ledges slightly thickened, outer cavity elliptic, boat-shaped, 12-15 $\mu \mathrm{m}$ long, rare simple filamentous trichomes up to $120 \mu \mathrm{m}$.

Remarks: This fossil species has been commonly recorded in the European Neogene and is quite characteristic in leaf morphology (e.g. Bůžek 1971). The epidermal structure clearly differs by peltate glandular trichomes from the modern species of Juglans including J. regia Linnaeus, usually cited as a modern analogue. A typical, broader form of "Juglans" acuminata from Arjuzanx (Kvaček et al. 2011) showed also peltate glandular trichomes in an unmacerated specimen embedded between glass slides. Morphologically similar but narrower impressions from the Pliocene of Willershausen (Knobloch 1998) were assigned to Cedrela heliconia (Unger) Erw. Knobloch, those from the Sarmatian from Bulgaria to Cedrela attica (Unger) Palamarev et Petkova (Palamarev et al. 2005). 


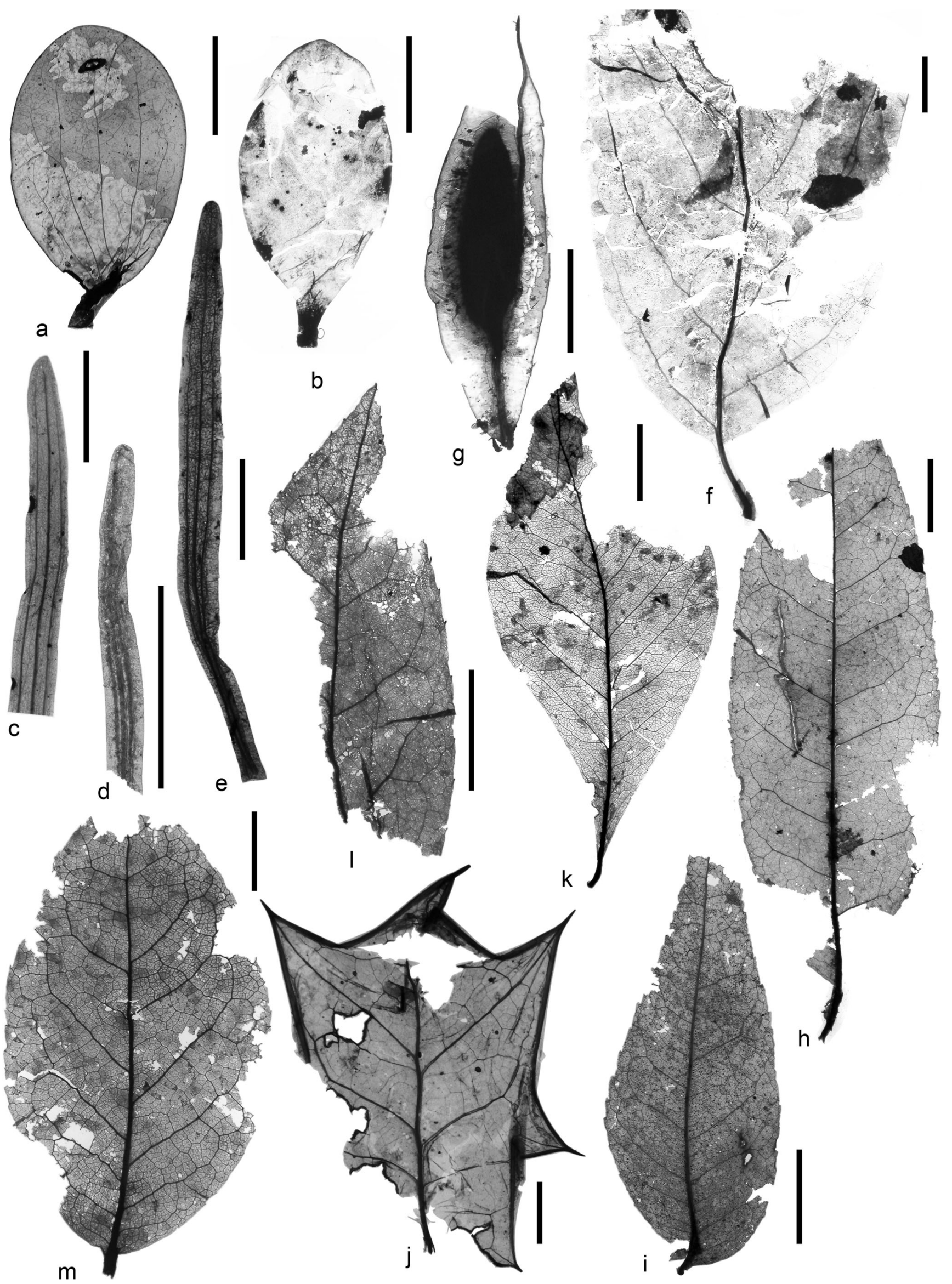


Fig. 14 a Viscum miquelii (Geyler et Kinkelin) Czeczott, complete leaf, SF.B 12461, 10 mm. b Viscum miquelii (Geyler et Kinkelin) Czeczott, complete leaf, neolectotype S 082703, $10 \mathrm{~mm}$. c Viscophyllum pliocaenicum (Engelhardt) Mädler, incomplete leaf, SF.B 12444, $10 \mathrm{~mm}$. d Viscophyllum pliocaenicum (Engelhardt) Mädler, incomplete leaf, neolectotype V.17170, $10 \mathrm{~mm}$. e Viscophyllum pliocaenicum (Engelhardt) Mädler, incomplete leaf, SF.B 12445, 10 mm. f Eucommia szaferi Kvaček, Teodoridis et Denk sp. nov., incomplete leaf, SF.B 12396, $10 \mathrm{~mm} . \mathbf{g}$ Eucommia szaferi Kvaček, Teodoridis et Denk sp. nov., fruit, SF.B 12163, $10 \mathrm{~mm}$. h Fraxinus angusta Hummel, incomplete leaflet, SF.B 12405, 10 mm. i Fraxinus angusta Hummel, complete leaflet, SF.B 12424, 10 mm. j llex geissertii Kvaček, Teodoridis, Wang Qing, incomplete leaf, SF.B 12780, $10 \mathrm{~mm}$. k Dicotylophyllum sp. A, incomplete leaf, SF.B 12384, $10 \mathrm{~mm}$. I Dicotylophyllum sp. B, incomplete leaf, SF.B 12403, $10 \mathrm{~mm}$. m Dicotylophyllum sp. B, complete leaf, SF.B 12399, $10 \mathrm{~mm}$

The abundant foliage of $J$. acuminata is associated with seeds of the Toona type at the early Miocene site Čermníky in North Bohemia (Bůžek 1971, p. 102, pl. 24, figs. 20-21, as Fructus vel semen). The affinity of the record from Frankfurt/M. to the Meliaceae is clearly demonstrated by the indumentum of the leaf. Foliage of various genera of Meliaceae is morphologically similar (e.g. Toona (Endlicher) M. Roemer of Asia and Australia, Cedrela P. Browne, Swietenia Jacquin of Mexico and Central America) but a lepidote indumentum is rarely present (e.g. in Aglaia Loureiro from the Philippines, Indonesia to Taiwan). Most modern species of Aglaia distributed in East and Southeast Asia (to Australia) have a lepidote foliage and match also in leaf morphology (e.g. A. lawii (Wight) C.J. Saldanha from Taiwan, Yunnan and elsewhere in southern Asia). Contrary to the mentioned evergreen representatives of Meliaceae, the studied fossil specimens differ by a papery (obviously deciduous) leaf lamina. In other occurrences of "Juglans" acuminata, most specimens are isolated leaflets and complete leaves are extremely rare (Heer 1859). We are unable to assign "Juglans" acuminata to a particular genus of the Meliaceae. Fossil Cedrela merrillii (Chaney) P. Brown from the North American Cenozoic differs by the wavy margin of the leaflets and associated seeds as documented by Meyer and Manchester (1997), 131, pl. 54, figs. 1-12).

Malvaceae Jussieu

Hibiscus Linnaeus

Hibiscus sp.

Figs. 12f, g and 180

? 1965 Hibiscus splendens Bajkovskaja in Kryshotofowicz et Bajkovskaja, p. 110, pl. 32, fig. 6, pl. 33, figs. 2-3, pl. 34, fig. 6

Material: SF.B 12252, 12263, 12263/1, 12347, cuticle preparation SF.B 12263.1-2.

Description: Leaves cordate, pentalobate to trilobate, widely coarsely toothed on abmedial margin of side lobes and medial lobe, partly entire, teeth apiculate, cuticles thin, adaxial cuticle showing straight-walled anticlines, cylindrical barrel-shaped glands divided into four to six segments dispersed on veinlets, stomata anomocytic, broadly elliptic, ledges thinly cutinised, pore short.

Remarks: A few compressions imitate Vitis and Acer in leaf morphology while leaf anatomy, particularly the indumentum with barrel-shaped polycellular glands clearly indicates Malvales (Kvaček and Wilde 2010). Foliage of some modern species of Hibiscus (e.g. H. mutabilis Linnaeus) is closely similar to the fossil species from Frankfurt. The previously described Hibiscus splendens Bajkovskaja, nom illegit. (non Graham) from the middle Miocene of Ukraine differs in less distinctly toothed margins.

\section{Dombeyopsis Unger}

aff. Dombeyopsis lobata Unger

Fig. $12 \mathrm{~h}$

1850 Dombeyopsis lobata Unger, p. 447

Material: SF.B 12194, ? 12220.

Description: One incomplete leaf base, leaf long petiolate, lamina deeply cordate, entire-margined, venation actinodromous, midrib and six lateral basal veins. Another incomplete leaf with shallow cordate base, actinodromous venation, and five basal veins may rather belong to a maple because of a single tooth on the lateral part.

Remarks: The compressions are not accessible for cuticle preparation. They co-occur at the site, with fruit remains of Craigia bronnii (as Ulmus longifolia Unger in Kräusel 1939, p. 86, pl. 8, fig. 2 and in Kräusel 1940, text-fig. 9b).

\section{Tilia Linnaeus}

? Tilia sp.

Fig. $12 \mathrm{i}$

\section{Material: SF.B 12271.}

Description: Incomplete small leaf without attached petiole, lamina cordate, lobate, broadly elliptic, middle lobe coarsely dentate, venation camptodromous to semicraspedodromous.

Remarks: Besides isolated bracts of Tilia (SF.B 12386, 12389, 12429), the associated incomplete leaf compression SF.B 12271 may represent foliage of this plant.

Santalaceae R. Brown (incl. Viscaceae Batsch) Viscum miquelii (Geyler et Kinkelin) Czeczott Figs. 14a, b and 19a

Material: S082696, S082703, SF.B 12455-12465, V. 17153, V. 17165, V. 17166, V. 26387, V. 26388.

Neolectotype: Specimen no. S082703 (Fig. 14b).

Description: Leaves elliptic, base widely cuneate and narrowing towards stout petiole, apex rounded, margin entire, venation basal acrodromous, five primary veins straight, venation of higher-order ramified. 

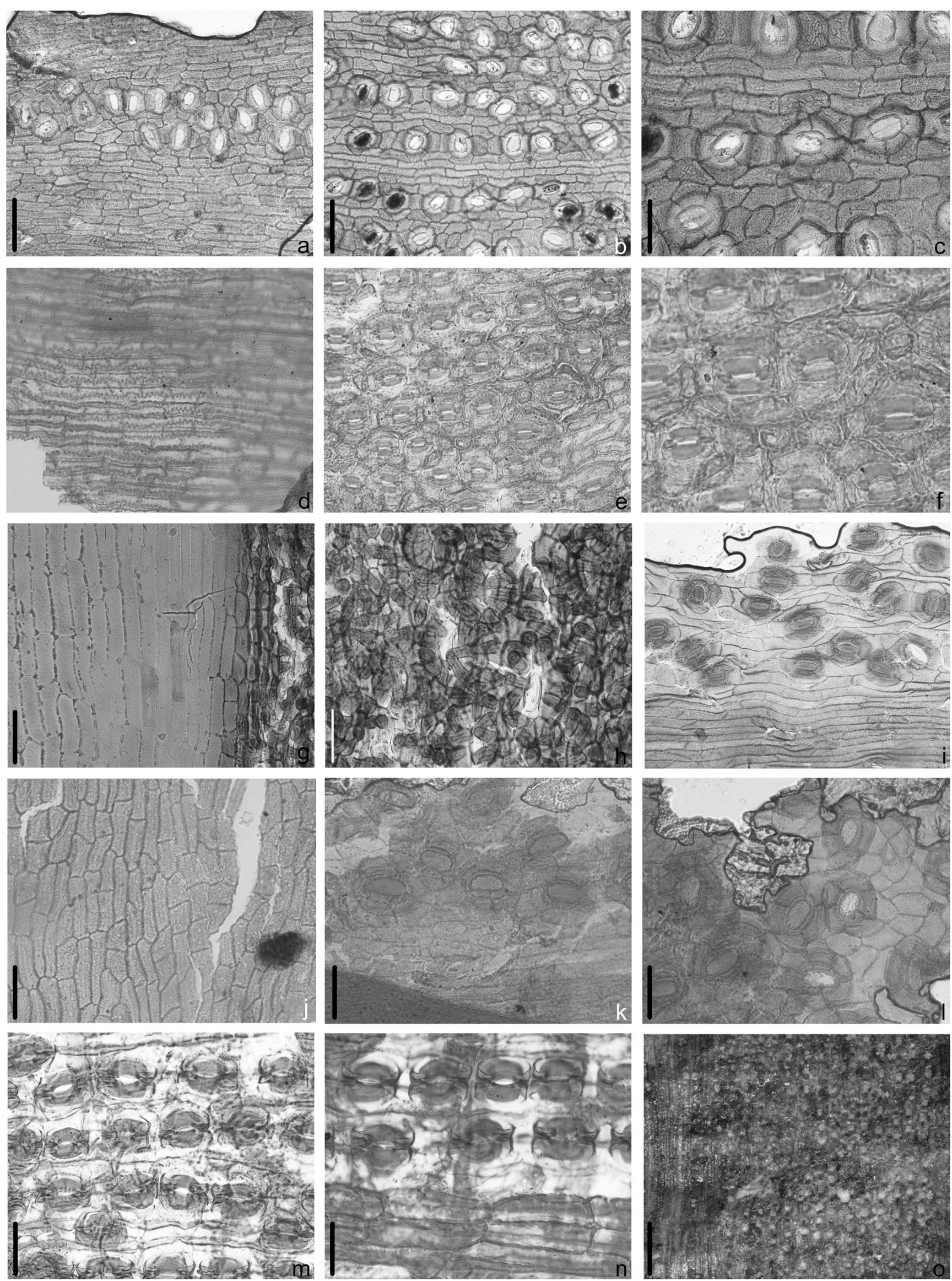
Fig. 15 a Cryptomeria rhenana Kilpper, adaxial cuticle, S117681.1, $50 \mu \mathrm{m}$. b Cryptomeria rhenana Kilpper, adaxial cuticle, S117681.1, $50 \mu \mathrm{m}$. c Cryptomeria rhenana Kilpper, abaxial cuticle, S117681.1, $100 \mu \mathrm{m}$. d Picea omoricoides C.A. Weber, adaxial cuticle, S117942.1, $50 \mu \mathrm{m}$. e Picea omoricoides C.A Weber, adaxial cuticle, S117942.1, $50 \mu \mathrm{m}$. f Picea omoricoides C.A. Weber, adaxial cuticle, S117942.1, $50 \mu \mathrm{m}$. g Sciadopitys tertiaria Menzel, adaxial cuticle, S118054.1, $50 \mu \mathrm{m}$. h Sciadopitys tertiaria Menzel, adaxial cuticle, S118054.1, 50 m. i Sequoia abietina (Brongniart) Erw. Knobloch adaxial cuticle, S118125, $50 \mu \mathrm{m}$. j Glyptostrobus europaeus (Brongniart) Unger adaxial cuticle, S118207.1, $50 \mu \mathrm{m}$. k Glyptostrobus europaeus (Brongniart) Unger adaxial cuticle, S118207.1, $50 \mu \mathrm{m}$. I Glyptostrobus europaeus (Brongniart) Unger adaxial cuticle, S118207.1, $100 \mu \mathrm{m}$. m Pseudotsuga kinkelinii (Mädler) Kvaček, Teodoridis et Denk comb. nov., S082700, 50 m. n Pseudotsuga kinkelinii (Mädler) Kvaček, Teodoridis et Denk comb. nov., S082700, 50 mm. o Pseudotsuga kinkelinii (Mädler) Kvaček, Teodoridis et Denk comb. nov., S082700, $25 \mu \mathrm{m}$

Remarks: The epidermal anatomy and relationship of the fossil species have been described and discussed several times (Knobloch and Kvaček 1976; Kovar-Eder and Krainer, 1991; Kvaček et al. 2008).

Viscophyllum pliocaenicum (Engelhardt) Mädler Figs. 14c-e and 19b

1908 Potamogeton pliocenicum Engelhardt in Engelhardt and Kinkelin, p. 225, pl. 27, fig. 25a-n

1939 Viscophyllum pliocaenicum (Engelhardt) Mädler, p. 91, pl. 8, figs. 8-9, pl. 11, fig. 5

Material: Original slides S082698, V.17170, V.25389, V.26336, V.26390, new material SF.B 12444, 12445, 12449, 12450.

Neolectotype: Specimen no. V17170 (fig. 14d).

Description: Leaves linear, up to $60 \mathrm{~mm}$ long and up to $5 \mathrm{~mm}$ wide, apex rounded, base truncate, margin entire, venation basal acrodromous, three primary veins straight, venation of higher-order ramified.

Remarks: The above listed material corresponds exactly to the partly destroyed type material. A new lectotype is established from the remaining specimens.

Eucommiaceae Engler

Eucommia Oliver

Eucommia szaferi Kvaček, Teodoridis et Denk sp. nov.

Figs. 14f, g and 19g-j

1954 Eucommia europaea Mädler sensu Szafer, p. 29, pro parte, pl. 6, figs. 9-14-15 (non 9-13, fruits)

1997 Eucommia sp., Hably and Kvaček, p. 37, pl. 16, figs. 84-86

2008 Eucommia sp., Kvaček, Teodoridis and Gregor, p. 12, pl. 14 , fig. $9-10$, pl. 15 , figs. 1,3 , pl. 23, figs. 11-13, pl. 24 , figs. 3-4

Holotype established here: SF.B 12396 (fig. 14f) and cuticle preparation SF.B 12396.1.
Other type material: SF.B 12160, 12162a, 12394, 12395, 12397?, 12398, 12402, 12473.

Derivatio nominis: In honour of the late Polish palaeobotanist, Prof. Władisław Szafer, Cracow, who firstly recognised foliage of Eucommia in the European Neogene.

Description: Leaves simple ovate, long petiolate, blade minutely serrate, venation semicraspedodromous. Adaxial cuticle faintly striate, unspecialised cells polygonal, 13-25 $\mu \mathrm{m}$ in diameter, anticlinal walls straight to slightly curved, abaxial cuticle fragmentary, anticlinal walls of ordinary cells slightly curved to shallow wavy, stomata anomocytic, elliptic, $17 \mu \mathrm{m}$ long, $10 \mu \mathrm{m}$ wide, dense mesophyllous fine bodies $10 \mu \mathrm{m}$ in diameter, dense gutapercha strands on veins.

Remarks: After the discovery of Eucommia fruits (Mädler 1939), Szafer (1954) reported a rich fossil record of this exotic plant (fruits, leaves) in the Polish Pliocene flora near Czorsztyn. Similar Eucommia leaves accompany the characteristic fruits at several Neogene sites in Europe (see Kvaček et al. 2008). They can be readily discriminated by gutapercha strands in the veins. Leaf impressions matching Eucommia in gross morphology have been described from the European Neogene in several cases and probably misinterpreted as they imitate alder foliage (e.g. Alnus acutidens Boulay 1890, pl. 6, fig. 9, Thésiers, France). Foliage attributed to Eucommia from the Sarmatian of Ukraina (E. palaeoulmoides Kryshtofowich et Bajkovskaja 1965) differs by its double dentate margin and requires re-examination.

Oleaceae Hoffmannsegg et Link

Fraxinus Linnaeus

Fraxinus angusta Hummel

Figs. $14 \mathrm{~h}-\mathrm{i}$ and $19 \mathrm{k}-\mathrm{m}$

1983 Fraxinus angusta Hummel, p. 79, pl. 51, figs. 1-4a, pl. 52, figs. 1-5a, pl. 53, figs. 1-6, text-figs. 31.9-20, 32.17

1998 Fraxinus pliocenica Erw. Knobloch, p. 81, pl. 54, fig. 1, pl. 59 , figs. $1-4$, pl. 61 , figs. 4,8

Material: SF.B 12404, 12405, 12406, 12407, 12409, 12410, $12411,12423,12424,12425,12426,12427$, cuticle preparation SF.B 12404.1.

Description: Leaflets sessile or shortly petiolulate, lamina ovate to elliptical, rounded at base, long acuminate at apex, fine serrate, venation semicraspedodromous, primary vein slightly curved, secondaries in more than 10 pairs, exterior tertiary veins terminating at margin. Adaxial cuticle smooth, ordinary cells $25-30(-50) \mu \mathrm{m}$ in diameter, anticlines coarsely undulate, solitary trichome bases rounded, with the periphery seen as a double line, rarely a peltate circular gland attached. Abaxial cuticle thin, slightly striate, stomata closely distributed, variable in size, anomocytic, elliptical, 15-30 $\mu \mathrm{m}$ long, 12-20 $\mu \mathrm{m}$ wide, stomatal ledges boat-like, slightly thickened, peltate solitary glands with $8-16$-celled shield, $35-50 \mu \mathrm{m}$ in 

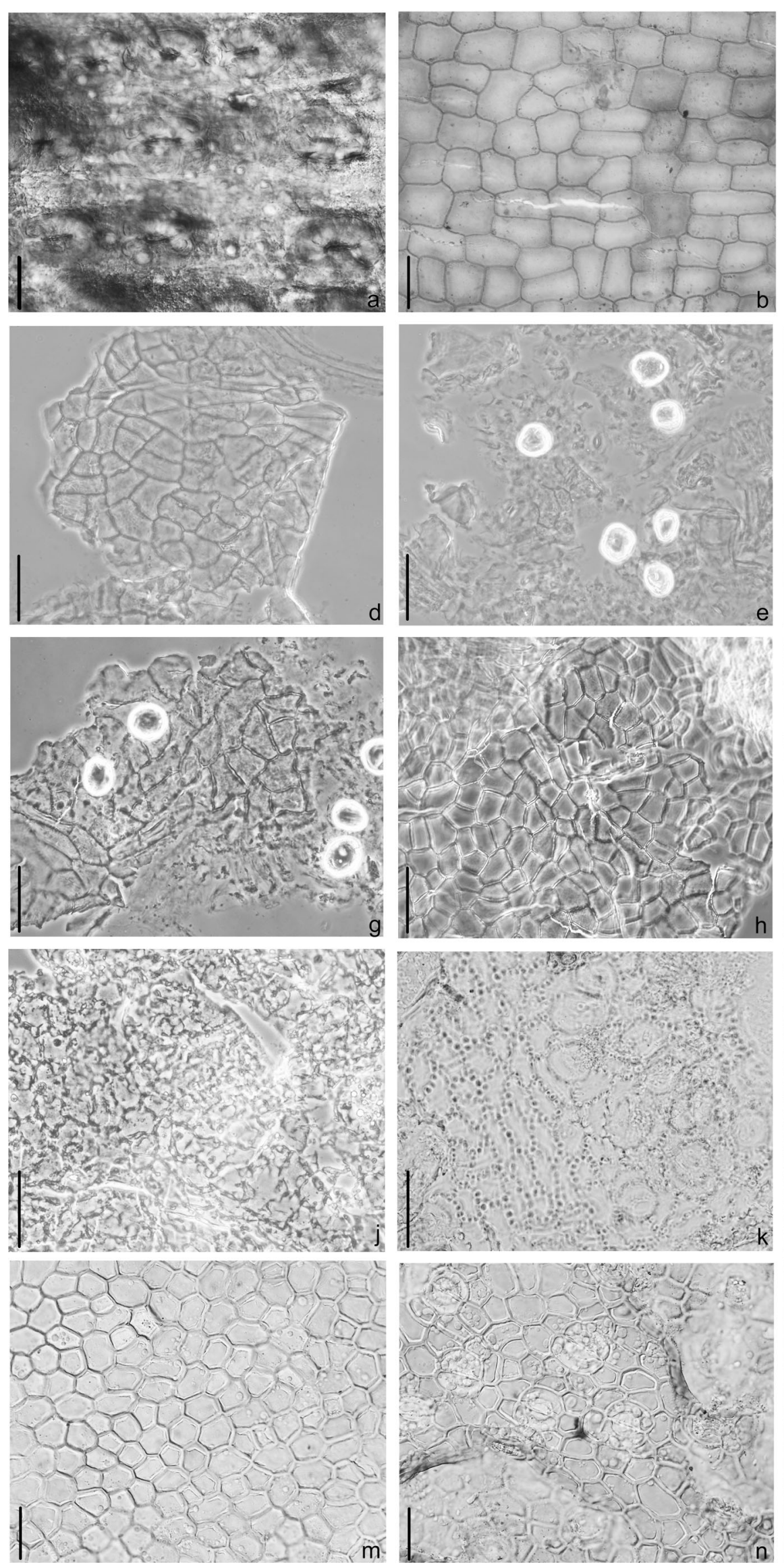
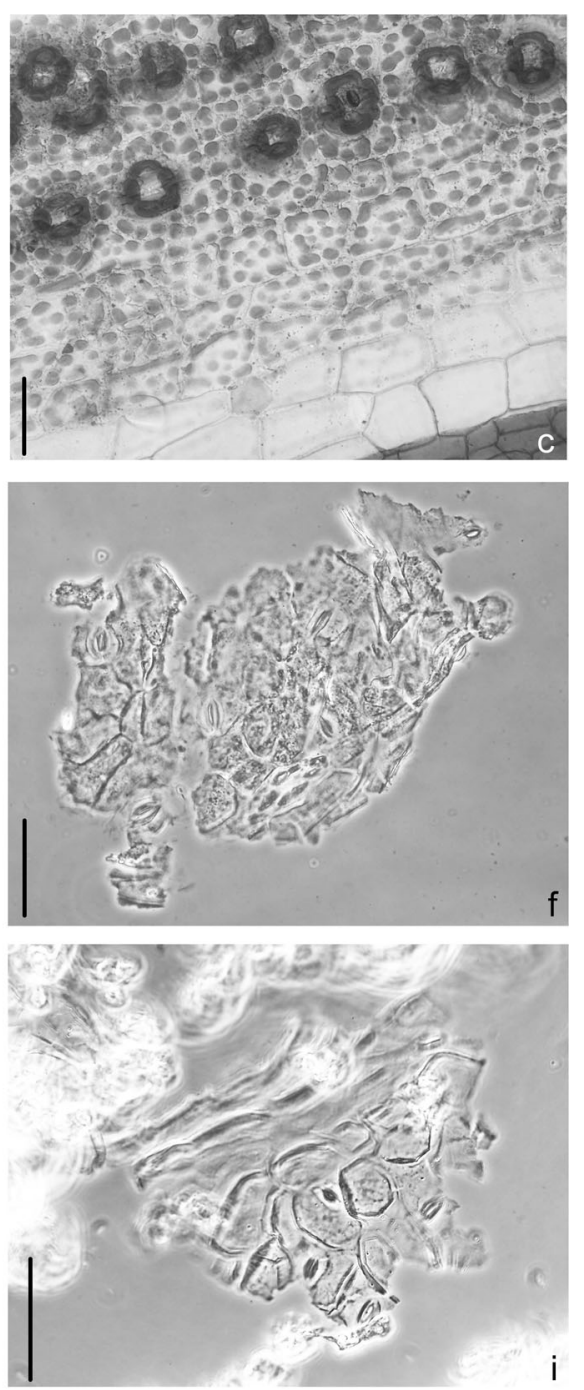

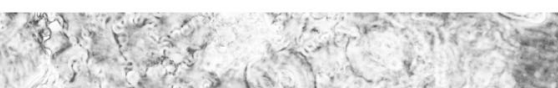

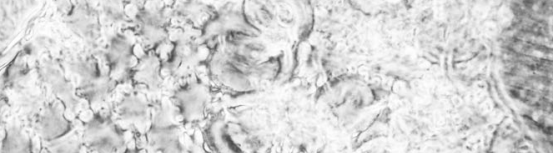

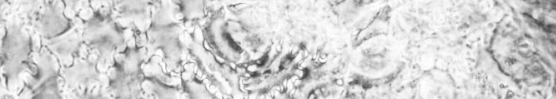
- 1400 and I In f MP

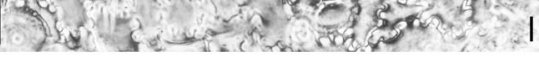

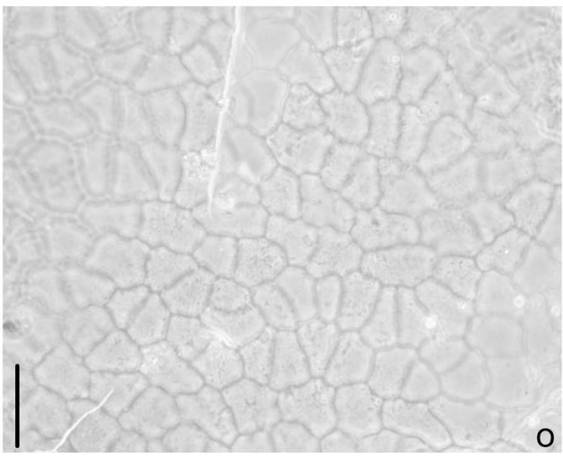


Fig. 16 a Pseudotsuga sclereidea (Mädler) Kvaček, Teodoridis et Denk comb. nov., S082707, $50 \mu \mathrm{m}$. b Taxus aff. baccata Linnaeus, adaxial cuticle, S082870, $50 \mu \mathrm{m}$. c Taxus aff. baccata Linnaeus, abaxial cuticle, S082870, 50 m. d Sassafras cf. ferretianum Massalongo et Scarabelli, adaxial cuticle, SF.B 12157, $50 \mu \mathrm{m}$. e Sassafras cf. ferretianum Massalongo et Scarabelli, abaxial cuticle, SF.B 12157, $50 \mu \mathrm{m}$. f Magnolia waltheri Kvaček, Teodoridis et Denk sp. nov., adaxial cuticle, SF.B 12157.1, 50 m. g Magnolia waltheri Kvaček, Teodoridis et Denk sp. nov., abaxial cuticle, SF.B 12157.1, $50 \mu \mathrm{m}$. h Magnolia waltheri Kvaček, Teodoridis et Denk sp. nov., adaxial cuticle, SF.B 12169.2, $50 \mu \mathrm{m}$. i Magnolia waltheri Kvaček, Teodoridis et Denk sp. nov., abaxial cuticle, SF.B 12169.2, $50 \mu \mathrm{m}$. j Magnolia liblarensis (Kräusel et Weyland) Kvaček, adaxial cuticle, SF.B 12438.1, 50 m. k Magnolia liblarensis (Kräusel et Weyland) Kvaček, abaxial cuticle, SF.B 12438.1, $50 \mu \mathrm{m}$. I Magnolia liblarensis (Kräusel et Weyland) Kvaček, abaxial cuticle, (phase contrast) B 12438.1, $50 \mu \mathrm{m}$. m Buxus pliocaenica Saporta, adaxial cuticle, S 082705, $50 \mu \mathrm{m}$. n Buxus pliocaenica Saporta, abaxial cuticle, S 082705, $50 \mu \mathrm{m}$. o Pachysandra europaea Kvaček, Teodoridis et Denk sp. nov., adaxial cuticle, SF.B 12393, $50 \mu \mathrm{m}$

diameter, stalk simple, $12 \mu \mathrm{m}$ across, trichome bases small rounded, simple.

Remarks: Both leaf morphology and epidermal anatomy indicate the affinity to Fraxinus. The epidermal structure corresponds to the description and illustration of Fraxinus angusta Hummel (1983) so far known only from the Pliocene site Ruszów, Poland. Morphologically similar foliage was described from the Pliocene flora of Willershausen (Knobloch 1998) including associated fruits and complete compound leaves. According to Hummel (1983), the epidermal structure of Fraxinus angusta is most similar to that of the modern F. excelsior Linnaeus native to Europe to Caucasus. Fruits of Fraxinus have also been recorded in the carpoflora of Frankfurt (Mädler 1939).

Aquifoliaceae Berchtold et J. Presl

Ilex Linnaeus

Ilex geissertii Kvaček, Teodoridis, Wang Qing

Figs. $14 \mathrm{j}$ and $19 \mathrm{n}$

1939 Ilex aquifolium Linnaeus fossilis Engelhardt; Mädler, p. 110 , pl. 8 , fig. 35 , pl. 13, fig. 3

2008 Ilex aquifolium Linnaeus fossilis Engelhardt; Kvaček, Teodoridis and Gregor, p. 28, pl. 8, figs. 10-13, pl. 20, figs. $3-5$

2009 Ilex geissertii Kvaček, Teodoridis, Wang Qing, p. 199, pls. 1-4, 8, figs. 1-6

Material: Original material of Mädler (1939) V. 17175, S082690, S082699; new specimens SF.B 12374, 12365, 12372, 12373. 12375, 12377, 12381, 12378, 12476, 12383, $12382,12371,12364,12363,12361,12362,12370,12369$, 12368, 12367, 12366.

Description: See Kvaček et al. (2009).
Remarks: For detailed description and comments, see Kvaček et al. (2009).

Angiospermae incertae familiae

Dicotylophyllum Saporta

The leaf remains described below cannot be assigned to particular families and genera in most cases. Remarks are only provided in cases where closer similarities to some taxa are observed. Cuticle preparations are available in rare cases, when leaf specimens were accessible to remove cuticle samples.

Dicotylophyllum sp. A

Fig. 14k

Material: SF.B 12384.

Description: Leaf ovate to lanceolate, entire-margined, base decurrent, lamina grading into a short stout petiole, base narrow cuneate, apex missing, venation camptodromous.

Remarks: This leaf remain conforms with the overall leaf morphology of Nyssa. Mädler (1939) reported stone fruits of Nyssa in the Pliocene flora of Frankfurt.

\section{Dicotylophyllum sp. B}

Fig. 141-m

Material: SF.B 12399, 12401, 12403, 12436, 12700.

Description: Leaf, petiolate, petiole 4 to $>10 \mathrm{~mm}$, lamina elliptic, $>40$ and $60 \mathrm{~mm}$ long, entire margined but with minute glandular teeth, secondary venation brochidodromous, with additional loops, intersecondary veins present, departing from primary vein at lower angles than secondary veins.

Remarks: Similar leaves are found in the Japanese extant species Styrax japonicus Siebold et Zuccarini. Mädler (1939) reported abundant seeds of Styrax obovatum (Weber) Mädler from the same site. According to Mädler, the fossil seeds are more similar to the Japanese $S$. japonicus than to the Mediterranean S. officinalis Linnaeus. The fossil differs from $S$. japonicus in the longer apical extension of the seed.

Dicotylophyllum sp. C

Fig. 13a

Material: B 12433.

Description: Leaf apex broadly elliptic to rounded, margin sub-entire, with widely scattered minute teeth.

Remarks: The fragment may represent the apex of a leaf of Dicotylophyllum sp. B.

Dicotylophyllum sp. D. 

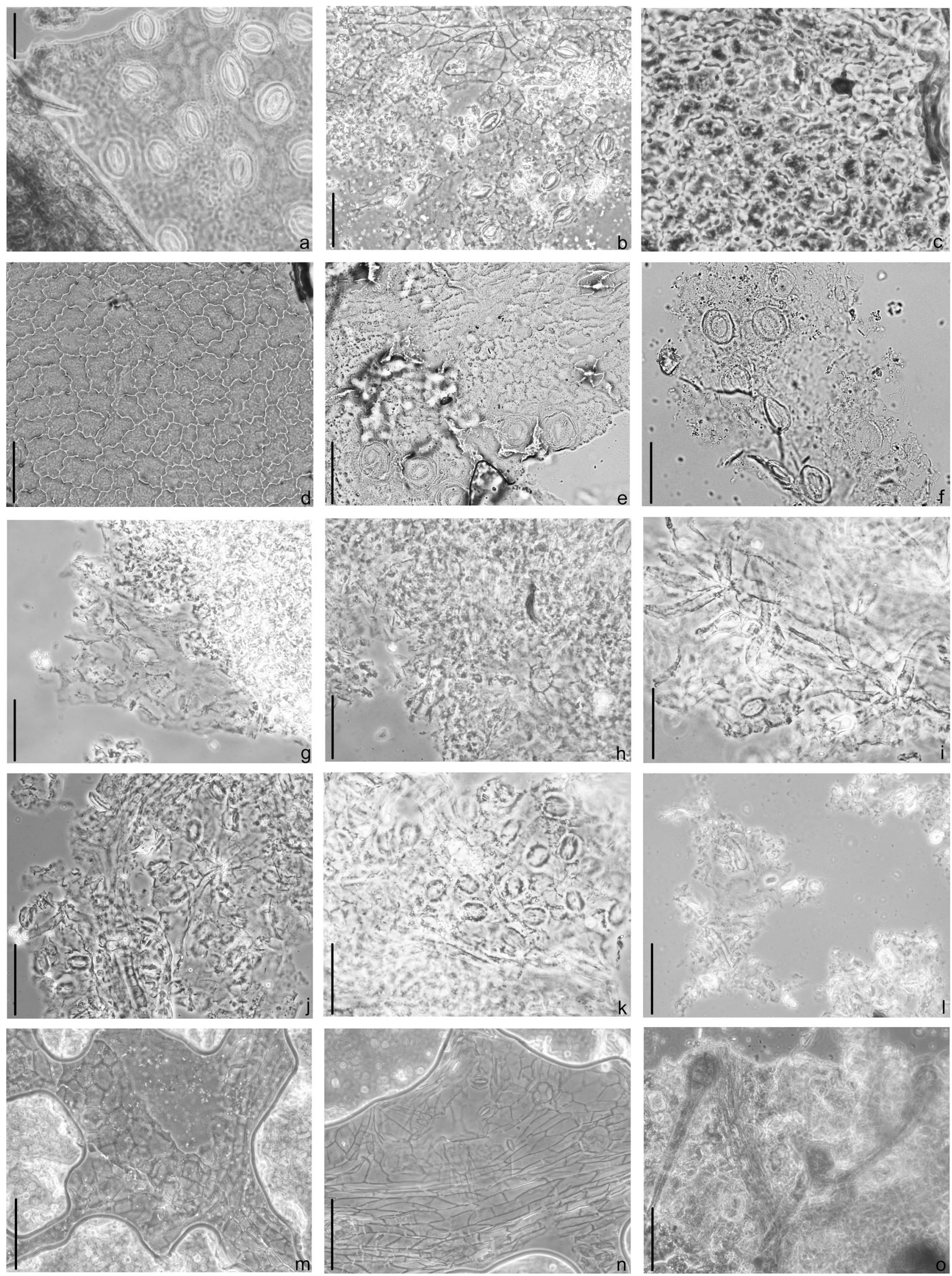
Fig. 17 a Pachysandra europaea Kvaček, Teodoridis et Denk sp. nov., abaxial cuticle, SF.B 12393, $50 \mu \mathrm{m}$. b Gleditsia pliocaenica Kvaček, Teodoridis et Denk sp. nov., abaxial cuticle, SF.B $12414.150 \mu \mathrm{m}$. c ? Prunus sp., adaxial cuticle, SF.B 12387.2, 50 um. d ? Prunus sp., abaxial cuticle with trichome bases, SF.B 12387.2, $50 \mu \mathrm{m}$. e ? Prunus sp., abaxial cuticle, SF.B 12387.1, $50 \mu \mathrm{m}$. f Castanea sp., abaxial cuticle, SF.B 11836, $50 \mu \mathrm{m}$. g Castanea sp., trichome base, SF.B 11836, $50 \mu \mathrm{m}$. h Quercus roburoides Gaudin sensu Erw. Knobloch, abaxial cuticle, SF. B 11805, $50 \mu \mathrm{m}$. i Quercus pseudocastanea Göppert sensu Walther et Zastawniak abaxial cuticle, SF.B 11786, $50 \mu \mathrm{m}$. j Quercus praecastaneifolia Erw. Knobloch abaxial cuticle, SF.B sn 11, $50 \mu \mathrm{m}$. k Quercus sp. abaxial cuticle, SF.B 11643, $50 \mu \mathrm{m}$. I Betula similis (Göppert) Zastawniak et Walther adaxial cuticle, SF.B 11806, $50 \mu \mathrm{m}$. m Betula similis (Göppert) Zastawniak et Walther abaxial cuticle, SF.B 11806, $50 \mu \mathrm{m}$. n Trichosanthes sp., abaxial cuticle with trichomes, SF.B $12191.1,50 \mu \mathrm{m}$

Figs. 13b, 19o and 20a

Material: SF.B 12440, cuticle preparation SF.B 12440.1. Description: Leaf lanceolate, margin sub-entire, sessile, venation brochidododromous with additional loops from which fine veins enter minute teeth, abaxial cuticle finely papillate, papillae $5 \mu \mathrm{m}$ across, stellate striation around stomata, stomata rounded elliptic, their maximum size $35 \times 20 \mu \mathrm{m}$, ledges thin and broad, pore spindle-shaped, slightly thickened, a single observation of a peltate trichome, ca. $50 \mu \mathrm{m}$ across, with simple thick base.

Remarks: By its leaf shape, this specimen resembles Salix; the venation is similar to Pterocarya or Cyclocarya. At this point, the botanical affinities remain uncertain.

\section{Dicotylophyllum sp. E}

Fig. 13c

\section{Material: SF.B 12434.}

Description: Leaf narrow oblanceolate, margin sub-entire, with solitary widely spaced minute teeth, base narrow cuneate and decurrent into a short stout petiole.

\section{Dicotylophyllum sp. F}

Fig. 13d

Material: SF.B 12435.

Description: Leaf elliptic, incomplete, long petiolate, margin entire, venation eucamptodromous.

Remarks: Similar to Diospyros Linnaeus.

Dicotylophyllum sp. G

Fig. 13e

Material: SF.B 12441.
Description: Leaf or leaflet, lamina elliptic, base rounded asymmetric, apex not preserved, margin sub-entire, with solitary distinct teeth in the lower part of the lamina and indistinct teeth higher up on one side of lamina, other side of lamina entire.

Remarks: This leaf remain might be a leaflet of a compound leaf.

Dicotylophyllum sp. H

Figs. 13f and 20c

Material: SF.B 12442, cuticle preparation SF.B 12442.1. Description: Leaf, lamina broad entire-margined rounded base, sessile (?), margin entire, venation brochidodromous. Cuticle thin, smooth, fine striations on veins, anticlinal walls straight, unspecialised cells $12-15 \mu \mathrm{m}$ in diameter, stomata probably on either leaf side, anomocytic (?), broadly elliptic, 15-37 long, 12-30 $\mu \mathrm{m}$ wide, size variable, outer stomatal ledges only slightly thickened, reaching to poles, surrounding boat-shaped aperture up to $25 \mu \mathrm{m}$ long and $12 \mu \mathrm{m}$ wide, single thin-walled trichome bases 5-12 $\mu \mathrm{m}$ across, densely dispersed on veins.

Dicotylophyllum sp. I

Fig. $13 \mathrm{~g}$

Material: SF.B 12433.

Description: Fragment of leaf, petiolate, base rounded acute, lamina narrow elliptic, margin entire, venation brochidodromous.

Dicotylophyllum sp. J

Figs. $13 \mathrm{~h}$ and $20 \mathrm{~d}-\mathrm{f}$

Material: SF.B 12431, cuticle preparation SF.B 12431.1. Description: Leaf fragment, lamina elliptic, secondary venation brochidodromous, loops widely spaced, intersecondary veins present, margin covered with short hairs, cuticles extremely thin, adaxial cells with coarsely wavy anticlines, up to $50 \mu \mathrm{m}$ in diameter, narrow polycellular trichome-like fringes on margin, abaxial cuticle smooth, fine papillate, anticlinal walls of unspecialised cells undulate, stomata probably anomocytic, broadly elliptic, 20-22 $\mu \mathrm{m}$ long, $15 \mu \mathrm{m}$ wide, ledges wide and thin, butterfly-like, surrounding very narrow pore, rare mesophyllous bodies present, 38-56 $\mu \mathrm{m}$ in diameter, cracked, solitary polycellular bases ca. $50 \mu \mathrm{m}$ in diameter, thin.

Remarks: Similar to some narrow-leaved modern species of Lonicera (e.g. L. maximowiczii (Ruprecht) Regel, L. angustifolia Wallich ex DC.) by the ciliate margin. All the so far published fossil foliage assigned to Lonicera, mostly from the European late Miocene and Pliocene, e.g. L. lipthayana Andreánszky (Andreánszky 1959; Palamarev and Kitanov 1988), Lonicera etrusca Santi (Stojanoff and Stefanoff 1929, p. 93, fig. 11, pl. 12, fig. 22, text-fig. 23), cf. L. etrusca Santi ? (Pop 1936, p. 98, 168, pl. 21, fig. 2), L. nigra Linnaeus (Stojanoff and Stefanoff 1929, 93, fig. 10, pl. 12, fig. 

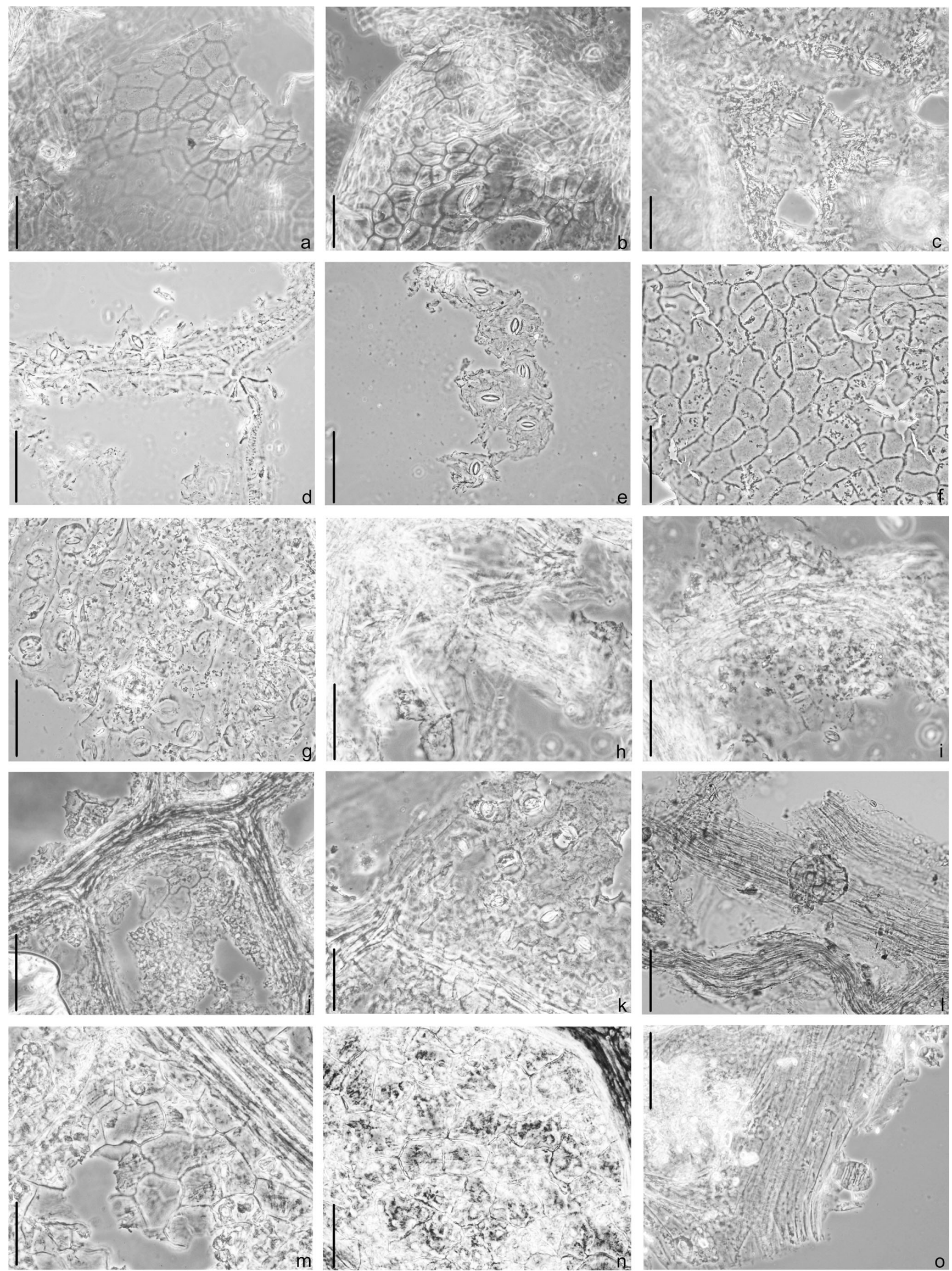
Fig. 18 a Salix cf. lavateri A. Braun sensu Hantke, adaxial cuticle, SF.B 11623.1, $50 \mu \mathrm{m}$. b Salix cf. lavateri A. Braun sensu Hantke, adaxial cuticle, SF.B 11623.1, $50 \mu \mathrm{m}$. c Salix cf. lavateri A. Braun sensu Hantke, abaxial cuticle, SF.B 11623.1, $50 \mu \mathrm{m}$. d Populus balsamoides Göppert, abaxial cuticle, SF.B 11670.1, $50 \mu \mathrm{m}$. e Populus balsamoides Göppert, abaxial cuticle, SF.B 11670.1, $50 \mu \mathrm{m}$. f Acer dombeyopsis Kvaček, Teodoridis et Denk sp. nov., adaxial cuticle, SF.B 12211.1, $50 \mu \mathrm{m}$. g Acer dombeyopsis Kvaček, Teodoridis et Denk sp. nov., abaxial cuticle, SF.B 12211.1, $50 \mu \mathrm{m}$. h Acer subcampestre Göppert, adaxial cuticle, SF.B 12324.1, $50 \mu \mathrm{m}$. i Acer subcampestre Göppert, abaxial cuticle, SF.B 12324.1, $50 \mu \mathrm{m}$. j Acer viburnoides Kvaček, Teodoridis et Denk sp. nov., abaxial and adaxial cuticle, SF.B 12210, $50 \mu \mathrm{m}$. k Acer aff. platanoides Linnaeus, abaxial cuticle, SF.B 12219.1, $50 \mu \mathrm{m}$. I Acer aff. platanoides Linnaeus, abaxial cuticle, SF.B 12324.1, $50 \mu \mathrm{m}$. m Acer vitiforme Kvaček, Teodoridis et Denk sp. nov., adaxial cuticle, SF.B 12319.1, 50 m. n Acer vitiforme Kvaček, Teodoridis et Denk sp. nov., abaxial cuticle, SF.B 12319.1. o Hibiscus sp., abaxial cuticle with trichomes, SF.B 12191.1, $50 \mu \mathrm{m}$

23, text-fig. 23), L. cf. xylosteum Linnaeus (Stefanoff and Jordanoff 1934, p. 36, pl. 3, fig. 21, pl. 8, figs. 19-20), Lonicera sp. A, B (Kryshtofovich and Baikovskaja 1965, p. 122, pl. 37, fig. 4, pl. 39, fig. 9) differ in the broader form (see also Němejc 1975, text-fig. 57.11). The leaf impressions from the middle Miocene of Island (see Grímsson et al. 2007; Denk et al. 2005, p. 410, figs. 203-206, as Dicotylophyllum sp. 2 ("Lonicera"); Grímsson et al. 2007, p. 21 as Lonicera sp.; Grímsson et al. 2007, pl. 9, figs. 5-6, as Dicotylophyllum sp. 1 ("Lonicera" sp.) are similar in venation pattern but are broader and do not show the ciliate margin. The ciliate margin alone is not genus diagnostic because such ciliate leaves are produced by more dicots, e.g. Diervilla lonicera Miller (eastern North America) and others (e.g. Rhododendron Linnaeus).

\section{Dicotylophyllum sp. K}

Fig. 13i

\section{Material: SF.B 12430.}

Description: Leaf, petiolate, lamina fragmentary, only basal part preserved, margin entire, secondary veins densely spaced, brochidodromous.

Remarks: Leaf may be similar to Maloideae C. Weber.

\section{Dicotylophyllum sp. L}

Figs. $13 \mathrm{j}$ and $20 \mathrm{~b}$

Material: SF.B 12437, cuticle preparation SF. B 12437.1. Description: Leaf, lamina elliptic, base cuneate, apex probably acuminate, margin entire, secondary venation eucamptodromous to brochidodromous, secondary veins branching once or twice. Cuticles of both adaxial and abaxial sides extremely thin, adaxial cuticle showing polygonal straight-walled cells, abaxial cuticle smooth, ordinary cells with wavy anticlines, stomata anomocytic, broadly elliptic, $25 \mu \mathrm{m}$ long, 15-18 $\mu \mathrm{m}$ wide, ledges thin, double, pore broadly elliptic, trichome bases simple rounded, 10-12 $\mu \mathrm{m}$ in diameter, dense near veins, surrounded by a rosette-like ring of quadrangular straight-walled isodiametric subsidiary cells, occasionally peltate glands and solitary simple trichomes preserved.

Remarks: This single leaf compression resembles in leaf morphology deciduous species of Rhododendron. Similar stomata and trichome bases were found in the entire-margined leaf fragment identified as ? "Diospyros" brachysepala Heer from the Pliocene of Gérce, Hungary (Hably and Kvaček 1997).

\section{Dicotylophyllum sp. M}

Fig. 13k

Material: SF.B 12156.

Description: Leaf base, long petiolate, narrow elliptic, not decurrent, margin entire, venation eucamptodromous.

Remarks: This foliage is similar to Laurophyllum but no lensshaped oil cells were observed. It is also similar to Magnolia but the leaf epidermal features are insufficient to securely place it within this genus.

\section{Dicotylophyllum sp. N}

Fig. 131

\section{Material: SF.B 12176.}

Description: Leaf apex acute, margin finely simple toothed, venation semicraspedodromous.

Dicotylophyllum sp. O

Figs. $13 \mathrm{~m}$ and $20 \mathrm{~g}, \mathrm{~h}$

Material: SF.B 12177, 12178, 12179, 12180, 12181, 12182 , cuticle preparation SF. B 12180.1.

Description: Leaves petiolate, ovate-elliptic, apex cuneate, base rounded, asymmetric, margin regularly sharply spinulous simple serrate, venation semicraspedodromous. SF. B 12180.1: Cuticles extremely thin, unspecialised cells with straight or slightly curved anticlines, stomata ? anomocytic, elliptic, 10-12 $\mu \mathrm{m}$ long, 7$10 \mu \mathrm{m}$ wide, pore narrow spindle-shaped, reaching to poles, ledges not thickened; peltate glands on veins with entire-margined head, $120 \mu \mathrm{m}$ in diameter, on simple rounded stalk, $15 \mu \mathrm{m}$ in diameter. Remarks: In marginal dentition, these leaves are similar to Clethra and Rosaceae. According to the leaf gross morphology (long petiolate leaves with spinulous margin and semicraspedodromous venation patterns), the fossil species resembles the Rosaceae subfamily Maloideae C. Weber, namely Pyrus ussuriensis Maximowicz native to Korea, Japan and the Ussuri River area of the Russian Far East, and allied Chinese species (see Rehder 1915). These species typically have leaves with long spinulose-serrate margin. However, the peltate glands found on the abaxial leaf side of one of the specimens (SF.B 12180) make the affinity to the Rosaceae improbable. Comparable leaves were assigned to Clethra Linnaeus from the Romanian late Miocene site Chiuzbaia (Givulescu 1990). The 

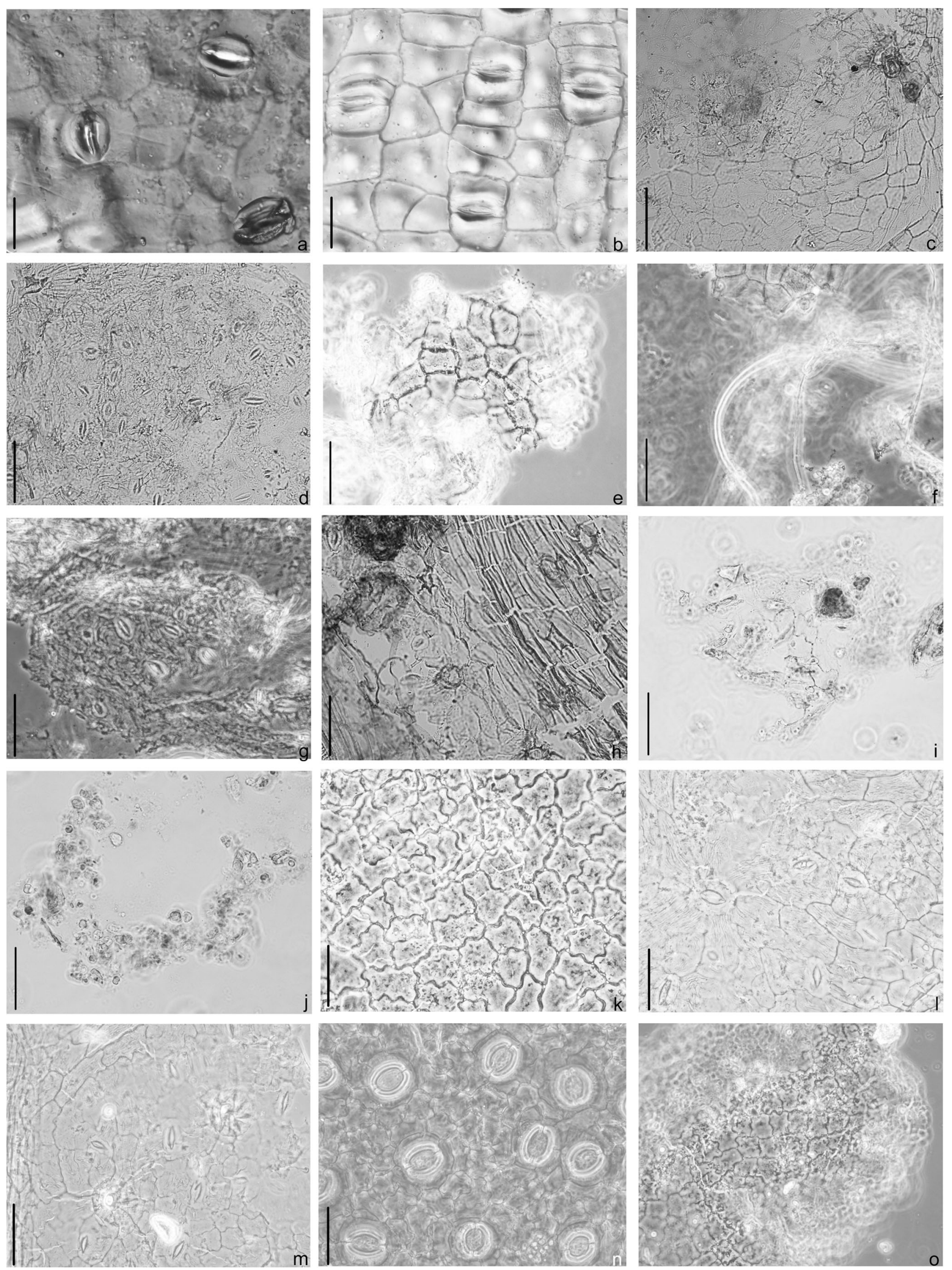
4 Fig. 19 a Viscum miquelii (Geyler et Kinkelin) Czeczott, leaf cuticle, S 082696.1, $50 \mu \mathrm{m}$. b Viscophyllum pliocaenicum (Engelhardt) Mädler, leaf cuticle S 082697.1, 50 m. c "Juglans" acuminata A. Braun, adaxial

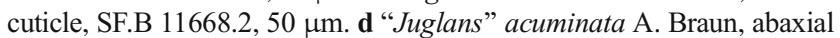
cuticle, SF.B 11668.2, $50 \mu \mathrm{m}$. e "Juglans" acuminata A. Braun, abaxial cuticle, SF.B 11668.2, $50 \mu \mathrm{m}$. f "Juglans" acuminata A. Braun, abaxial cuticle with trichome bases, SF.B 11668.2, $50 \mu \mathrm{m}$. g Eucommia szaferi Kvaček, Teodoridis et Denk sp. nov., adaxial cuticle, SF.B 12396.1, $50 \mu \mathrm{m}$. h Eucommia szaferi Kvaček, Teodoridis et Denk sp. nov., adaxial cuticle with gutapercha strands, SF.B 12396.1, $50 \mu \mathrm{m}$. i Eucommia szaferi Kvaček, Teodoridis et Denk sp. nov., abaxial cuticle, SF.B 12396.1, $50 \mu \mathrm{m}$. j Eucommia szaferi Kvaček, Teodoridis et Denk sp. nov., mesophyllous bodies, SF.B 12396.1, $50 \mu \mathrm{m}$. k Fraxinus angusta Hummel, adaxial cuticle, SF.B 12404.1, $50 \mu \mathrm{m}$. I Fraxinus angusta Hummel, abaxial cuticle, SF.B 12404.1, $50 \mu \mathrm{m}$. m Fraxinus angusta Hummel, abaxial cuticle with peltate trichomes, SF.B 12404.1, $50 \mu \mathrm{m}$. n Ilex geissertii Kvaček, Teodoridis, Wang Qing, abaxial cuticle, SF.B 12219.1, 50 m. o Dicotylophyllum sp. D, adaxial cuticle, SF.B 12440.1, $50 \mu \mathrm{m}$
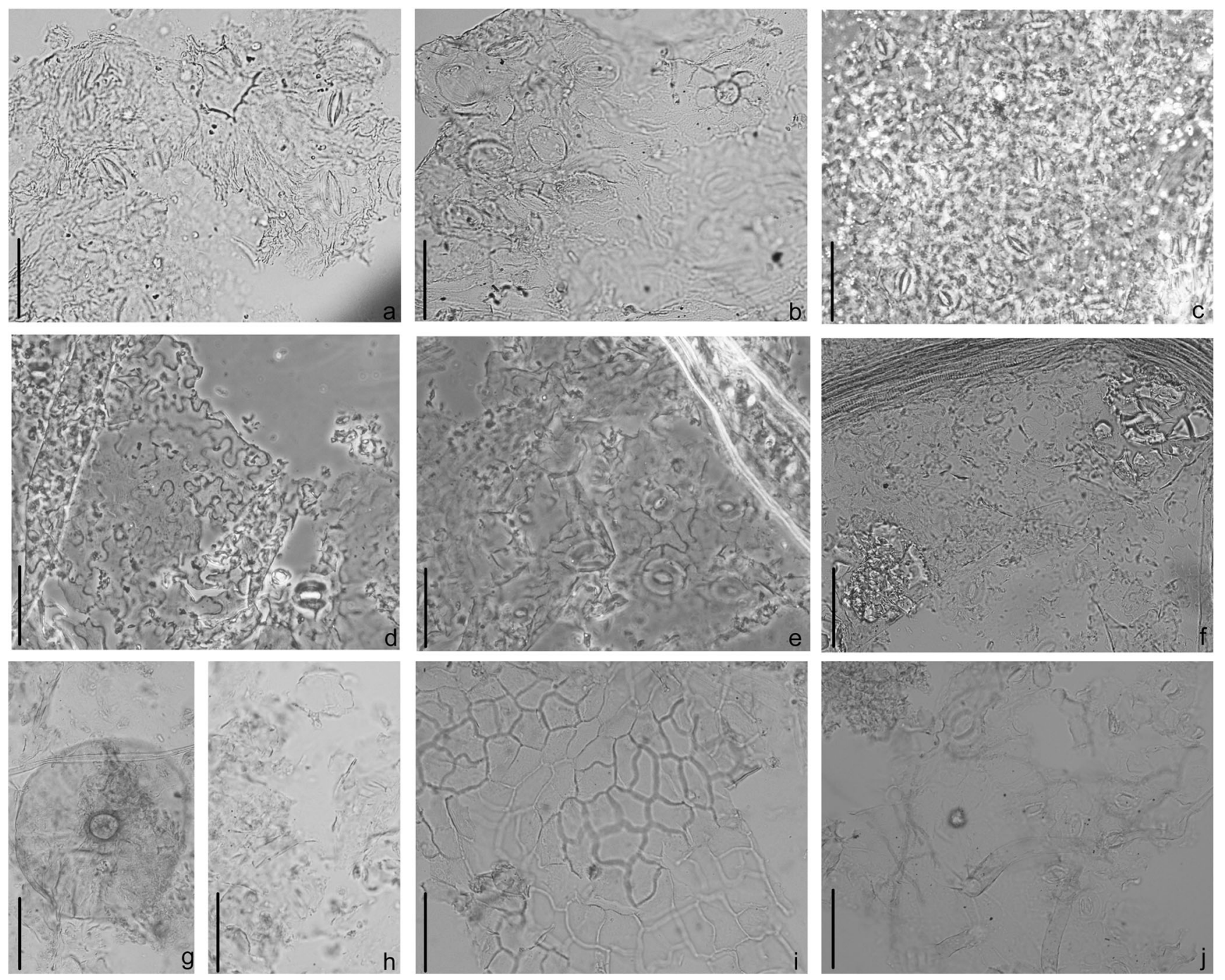

Fig. 20 a Dicotylophyllum sp. D, abaxial cuticle, SF.B 12440.1, $50 \mu \mathrm{m}$. b Dicotylophyllum sp. L, abaxial cuticle, SF.B 12437.1, $50 \mu \mathrm{m}$. c Dicotylophyllum sp. H, abaxial cuticle, SF.B 12442.1, $50 \mu \mathrm{m}$. d Dicotylophyllum sp. J, adaxial cuticle, SF.B 12431.1, $50 \mu \mathrm{m}$. e Dicotylophyllum sp. J, abaxial cuticle, SF.B 12431.1, $50 \mu \mathrm{m}$. f Dicotylophyllum sp. J, abaxial cuticle with mesophyll bodies, SF.B
12431.1, $50 \mu \mathrm{m}$. g Dicotylophyllum sp. O, abaxial cuticle with peltate trichome, SF. B 12180.1, $50 \mu \mathrm{m}$. h Dicotylophyllum sp. O, abaxial cuticle, SF. B 12180.1, $50 \mu \mathrm{m}$. i Acer integerrimum (Viviani) Massalongo, adaxial cuticle, SF.B 12243.1, $50 \mu \mathrm{m}$. j Acer integerrimum (Viviani) Massalongo, abaxial cuticle, SF.B 12243.1, $50 \mu \mathrm{m}$ 
Table 1 Genera recorded from the Pliocene flora of Frankfurt/M. and their modern biogeographic relationships

\begin{tabular}{|c|c|c|c|c|}
\hline Fossil taxon (genus level) [no. species] & wEUR & EA & eNA & wNA \\
\hline Ginkgo & 0 & 1 & 0 & 0 \\
\hline Calocedrus & 0 & 1 & 0 & 1 \\
\hline Cryptomeria & 0 & 1 & 0 & 0 \\
\hline Glyptostrobus & 0 & 1 & 0 & 0 \\
\hline Sequoia & 0 & 0 & 0 & 1 \\
\hline Taxodium & 0 & 0 & 1 & 1 \\
\hline Abies & 1 & 1 & 1 & 1 \\
\hline Picea & 1 & 1 & 1 & 1 \\
\hline Pinus & 1 & 1 & 1 & 1 \\
\hline Pseudotsuga [2] & 0 & 1 & 0 & 1 \\
\hline Tsuga & 0 & 1 & 1 & 1 \\
\hline Sciadopitys & 0 & 1 & 0 & 0 \\
\hline Cephalotaxus & 0 & 1 & 0 & 0 \\
\hline Taxus & 1 & 1 & 1 & 1 \\
\hline Torreya & 0 & 1 & 1 & 1 \\
\hline Magnolia [2] & 0 & 1 & 1 & 0 \\
\hline Sassafras & 0 & 1 & 1 & 0 \\
\hline Smilax & 1 & 1 & 1 & 1 \\
\hline Buxus & 1 & 1 & 1 & 1 \\
\hline Pachysandra & 0 & 1 & 1 & 0 \\
\hline Liquidambar & 1 & 1 & 1 & 0 \\
\hline Parrotia & 1 & 0 & 0 & 0 \\
\hline Cercidiphyllum & 0 & 1 & 0 & 0 \\
\hline Gleditsia & 1 & 1 & 1 & 0 \\
\hline Podocarpium $\dagger$ & 1 & 1 & 0 & 0 \\
\hline Crataegus & 1 & 1 & 1 & 1 \\
\hline Malus & 1 & 1 & 1 & 1 \\
\hline Prunus & 1 & 1 & 1 & 1 \\
\hline Rosa & 1 & 1 & 1 & 1 \\
\hline Sorbus & 1 & 1 & 1 & 1 \\
\hline Spiraea & 1 & 1 & 1 & 1 \\
\hline Ulmus [2] & 1 & 1 & 1 & 1 \\
\hline Zelkova & 1 & 1 & 0 & 0 \\
\hline Fagus & 1 & 1 & 1 & 0 \\
\hline Castanea & 1 & 1 & 1 & 0 \\
\hline Quercus [5] & 1 & 1 & 1 & 1 \\
\hline Carya & 0 & 1 & 1 & 0 \\
\hline Pterocarya & 1 & 1 & 0 & 0 \\
\hline Alnus & 1 & 1 & 1 & 1 \\
\hline Betula & 1 & 1 & 1 & 1 \\
\hline Carpinus [2] & 1 & 1 & 1 & 0 \\
\hline Corylus & 1 & 1 & 1 & 1 \\
\hline Trichosanthes & 0 & 1 & 0 & 0 \\
\hline Salix & 1 & 1 & 1 & 1 \\
\hline Populus [4] & 1 & 1 & 1 & 1 \\
\hline Celtis & 1 & 1 & 1 & 1 \\
\hline Acer [7] & 1 & 1 & 1 & 1 \\
\hline Aesculus & 1 & 1 & 1 & 1 \\
\hline Meliaceae-Cedrela & 1 & 0 & 0 & 0 \\
\hline Hibiscus & 1 & 1 & 1 & 1 \\
\hline Dombeyopsis $\dagger$ & 1 & 0 & 0 & 0 \\
\hline Tilia & 1 & 1 & 1 & 0 \\
\hline Viscum & 1 & 1 & 0 & 0 \\
\hline Eucommia & 0 & 1 & 0 & 0 \\
\hline Fraxinus & 1 & 1 & 1 & 1 \\
\hline Ilex & 1 & 1 & 1 & 1 \\
\hline Total & 38 & 51 & 38 & 31 \\
\hline
\end{tabular}

$w E U R=$ western Eurasia, $E A=$ East Asia,$e N A=$ eastern North, America, $w N A=$ western North America, $\digamma=$ extinct genus, $l=$ present, $0=$ absent a sandy clay lens had become exposed during the construction of the clearing basin of the sewage treatment plant in Frankfurt/Niederrad. The depositional setting of the flora makes a closer age determination difficult, and various authors have suggested a late Miocene, early and late Pliocene, or even Quaternary age for the plant assemblage of Frankfurt/ M (cf. Mädler 1939). The general regional lithology comprises sand and gravel on top of clays or surrounding clay lenses and lignites (Martini et al. 2011). Zagwijn (1960) established a palyno-stratigraphic framework for the late Miocene to early Pliocene in the Netherlands and made a clear distinction between the early Pliocene Brunssumian and the late Pliocene Reuverian. Previously, Reid and Reid (1915) had considered the carpofloras of Reuver and Brunssum coeval. Zagwijn (1960) listed a number of pollen taxa that he considered typical of the Brunssumian and Reuverian stages. The Brunssumian was characterised by high values of Sequoia-type pollen and the presence of Rhus, Symplocos, Tricolporopollenites (Tricolporites) megaexactus, Edmundipollis edmundi (Tricolporites edmundi), Sapotaceae and Engelhardioideae among others. Other elements, found also in the Frankfurt flora, were common throughout the Pliocene (Pterocarya, Carya, Eucommia, Aesculus, Liquidambar, Castanea; Zagwijn 1960). Kemna and Westerhoff (2007) objected that the Sequoia-type pollen peak found by Zagwijn was not a reliable feature to identify the Brunssumian stage but acknowledged that the presence of Symplocos and Edmundipollis edmundi were more diagnostic of the first half of the Pliocene. According to Stuchlik et al. (2014), the pollen taxon Edmundipollis edmundi has closest botanical affinities with the extant genus Diplopanax (Cornales, Nyssaceae). Both Symplocos and Diplopanax are absent from the leaf and carpological record of Frankfurt (Supplementary material File 1).

Mohr (1986) investigated a 2.5-m pollen profile from Willershausen und based on the rare occurrence of Symplocos, and the absence of other "older" elements such as Sapotaceae, Engelhardioideae suggested a Reuverian age for the flora of Willershausen. This age was accepted by Knobloch (1998). Mai (1995), based on the presence of warmth-loving relicts, distinguished a "Florenkomplex Brunssum" and a "Florenkomplex Reuver". While placing Frankfurt/M and the "main fossiliferous horizon" of Auenheim (Alsace) in the Floren-komplex Brunssum, Mai (1995) considered the floras of Willershausen and Berga to be of Reuverian age.

Based on the work by Geissert (1972) and Geissert et al. (1990), Kvaček et al. (2008), fig. 2) correlated the Pliocene leaf flora of Auenheim (Alsace, France) with the "Villafranchian" strata of Geissert (1972) and suggested a late Pliocene age (Reuverian). The leaf flora of Frankfurt/M is virtually identical with the one from 
Table 2 Selected climate parameters for relict taxa in the Pliocene flora of Frankfurt

\begin{tabular}{|c|c|c|c|c|c|}
\hline Taxon & Distribution & $\mathrm{MAT}_{\min }$ & MAT $_{\max }$ & $\mathrm{MTCM}_{\min }$ & $\mathrm{MTCM}_{\max }$ \\
\hline Cryptomeria japonica & EA & 5.4 & 21 & -3.5 & 14.2 \\
\hline Cunninghamia lanceolata & EA & 2 & 24.7 & -7.2 & 19.8 \\
\hline Glyptostrobus pensilis & EA & 10.6 & 23 & -0.2 & 15.2 \\
\hline Calocedrus macrolepis & EA & 14.3 & 24.3 & 4 & 18.7 \\
\hline Calocedrus decurrens & NA & 3.7 & 19.4 & -5.4 & 8.0 \\
\hline Cephalotaxus fortunei & EA & 2.2 & 23 & -7 & 17.7 \\
\hline Cephalotaxus lanceolata & EA & 2.2 & 18.5 & -7 & 10.5 \\
\hline Cephalotaxus latifolia & EA & 9 & 21.2 & 0.6 & 12.8 \\
\hline Cephalotaxus mannii & EA & 13.1 & 24.8 & 5.4 & 20.1 \\
\hline Cephalotaxus oliveri & EA & 9.3 & 21.4 & -1.7 & 14.2 \\
\hline Cephalotaxus sinensis & EA & 2.6 & 24.7 & -7 & 19.8 \\
\hline Torreya fargesii & EA & 7.3 & 16.2 & -2.5 & 6.2 \\
\hline Torreya f. var. yunnanensis & EA & 6.1 & 14.3 & -1.5 & 7.6 \\
\hline Torreya grandis & EA & 12.7 & 18.2 & 0.5 & 9 \\
\hline Torreya jackii & EA & 15.0 & 17.0 & 3.5 & 7.2 \\
\hline Torreya californica & NA & 8.0 & 16.0 & 0.0 & 9.0 \\
\hline Taxodium distichum & NA & 12.6 & 24.1 & -1.4 & 19.3 \\
\hline Taxodium mucronatum & NA & 13.9 & 26.1 & 8.9 & 24.0 \\
\hline Aesculus assamica & EA & 15.1 & 22.2 & 5.0 & 15.1 \\
\hline Aesculus californica & NA & 8.6 & 17.0 & 1.7 & 9.2 \\
\hline Aesculus chinensis & EA & 3.5 & 16.9 & -6.5 & 5.5 \\
\hline Aesculus glabra & NA & 8.0 & 24.3 & -9.1 & 10.2 \\
\hline Aesculus octandra & NA & 8.0 & 15.5 & -3.8 & 5.1 \\
\hline Aesculus parviflora & NA & 15.4 & 19.2 & 4.0 & 10.1 \\
\hline Aesculus pavia & NA & 11.9 & 21.9 & -0.8 & 15.4 \\
\hline Aesculus sylvatica & EA & 12.8 & 17.4 & 1.7 & 7.4 \\
\hline Liquidambar formosana & EA & 2.2 & 24.8 & -6.6 & 20.1 \\
\hline Liquidambar styraciflua & NA & 9.3 & 25.3 & -3.6 & 23.8 \\
\hline Nyssa aquatica & NA & 12.0 & 20.9 & -2.4 & 13.0 \\
\hline Nyssa javanica & EA & 8.6 & 24.0 & 1.3 & 19.1 \\
\hline Nyssa leptophylla & EA & 15.8 & 15.8 & 4.6 & 4.6 \\
\hline Nyssa ogeche & NA & 18.3 & 20.5 & 8.9 & 13.5 \\
\hline Nyssa sinensis & EA & 10.6 & 22.7 & -0.2 & 15.1 \\
\hline Nyssa sylvatica & NA & 4.5 & 23.0 & -10.4 & 18.9 \\
\hline Quercus aliena & EA & 2.2 & 21.0 & -15.9 & 15.1 \\
\hline Quercus aliena v. acutiserrata & EA & 5.4 & 21.0 & -13.5 & 15.1 \\
\hline Quercus fabri & EA & 2.6 & 21.3 & -7.0 & 15.2 \\
\hline Quercus griffithii & EA & 5.4 & 20.5 & -2.1 & 15.1 \\
\hline Sassafras albidum & NA & 5.6 & 22.0 & -8.7 & 15.5 \\
\hline Sassafras tzumu & EA & 9.3 & 22.8 & -3.3 & 14.7 \\
\hline
\end{tabular}

Climate data from Thompson et al. (1999a, 1999b, 2000) and Fang et al. (2011)

$M A T=$ mean annual temperature in $\mathrm{C}^{\circ}, \mathrm{MTCM}=$ mean temperature of the coldest month in $\mathrm{C}^{\circ}, E A=$ East Asia, $N A=$ North America

Auenheim (Kvaček et al. 2008 and present study). Therefore, we tentatively suggest a Reuverian age for this leaf flora. Palynofloras from drill cores in the surroundings of Frankfurt/M. and Hanau also suggested a late Pliocene age (Martini et al. 2011).
Comparison of the leaf and carpofloras of Frankfurt

Mädler (1939) described 98 taxa based on fruits and seeds for the Pliocene flora of Frankfurt. Eight species were described as new species (Supplementary material 
Fig. 21 Possible climate analogues for the Pliocene of Frankfurt. a Walter-climate diagram. Lugano in southern Switzerland has a typical temperate climate, $\mathrm{Cf}$ climate according to the Köppen-Geiger climate classification. There is no period during the year where rainfall is a limiting factor; summer months are characterised by highest temperatures and precipitation. $\mathbf{b}$ Walter-climate diagram.

Santander in northern Spain has a sub-Mediterranean climate. Rainfall is limited during the summer months but there is no arid period during the summer as in Mediterranean climates. c Climate variables for Lugano indicating, among others, the mean temperature of the coldest month. All figures from Lieth et al. (1999)
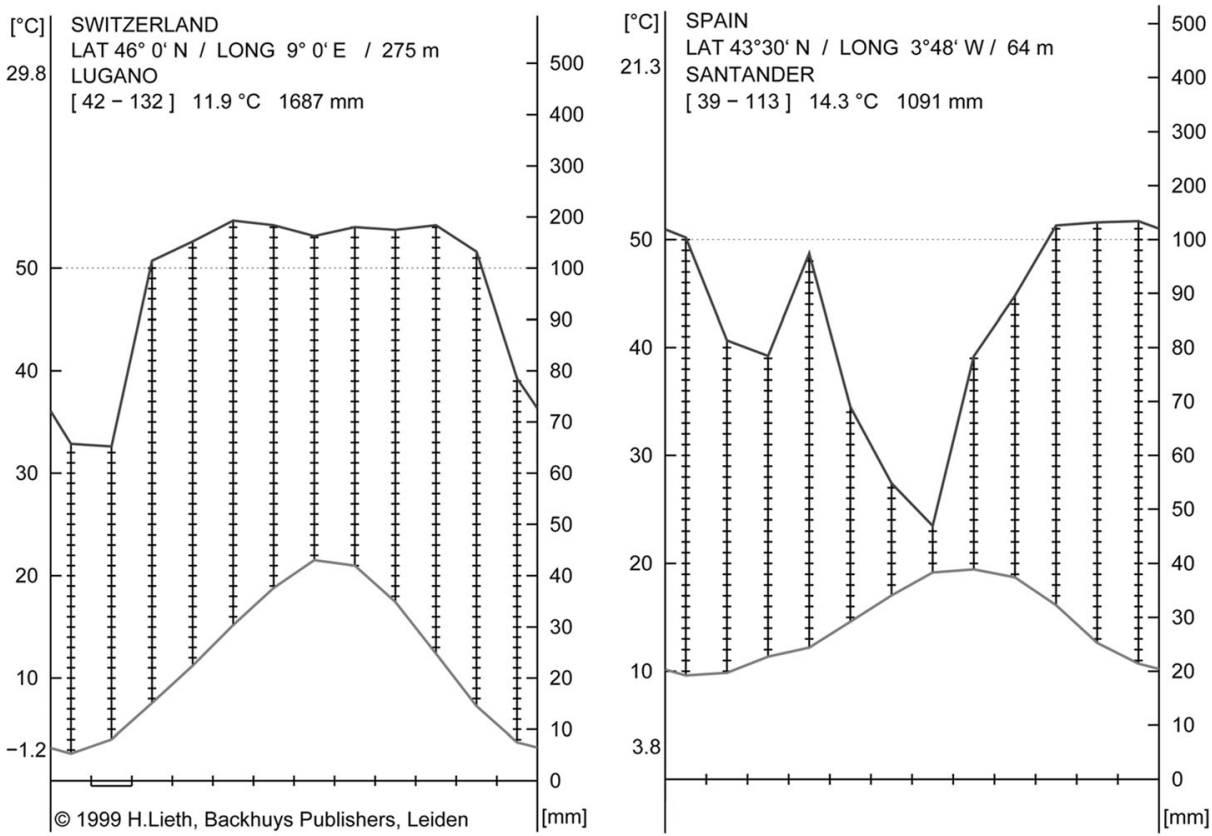

a

b

Recorded Period: P (1861-1993), T (1951-1993)

\begin{tabular}{|l|l|l|l|l|l|l|l|l|l|l|l|l|}
\hline & JAN & FEB & MAR & APR & MAY & JUN & JUL & AUG & SEP & OCT & NOV & DEC \\
\hline $\begin{array}{l}\text { Mean daily } \\
\text { temperature } \\
{\left[{ }^{\circ} \mathrm{C}\right]}\end{array}$ & 2.6 & 4.0 & 7.6 & 11.2 & 15.2 & 18.8 & 21.5 & 21.0 & 17.4 & 12.4 & 7.3 & 3.7 \\
\hline $\begin{array}{l}\text { Mean daily } \\
\text { temp., min } \\
{\left[{ }^{\circ} \mathrm{C}\right]}\end{array}$ & 0.0 & -1.2 & 4.9 & 9.3 & 11.5 & 17.0 & 18.7 & 18.6 & 14.0 & 8.7 & 5.2 & 1.8 \\
\hline $\begin{array}{l}\text { Mean daily } \\
\text { temp., max } \\
{\left[{ }^{\circ} \mathrm{C}\right]}\end{array}$ & 4.7 & 7.1 & 10.5 & 13.4 & 18.1 & 21.3 & 23.8 & 29.8 & 20.5 & 14.0 & 9.1 & 10.0 \\
\hline $\begin{array}{l}\text { Mean } \\
\text { precipitation } \\
\text { [mm] }\end{array}$ & 65.7 & 65.2 & 114.7 & 152.2 & 192.9 & 183.8 & 162.9 & 180.2 & 175.0 & 183.9 & 132.3 & 78.5 \\
\hline $\begin{array}{l}\text { Minimum } \\
\text { precipitation } \\
\text { [mm] }\end{array}$ & 0.0 & 0.0 & 0.0 & 0.0 & 8.0 & 29.0 & 14.0 & 6.0 & 1.0 & 0.0 & 1.0 & 0.0 \\
\hline $\begin{array}{l}\text { Maximum } \\
\text { precipitation } \\
\text { [mm] }\end{array}$ & 285.0 & 391.0 & 355.0 & 512.0 & 519.0 & 444.0 & 387.0 & 575.0 & 592.0 & 797.0 & 530.0 & 352.0 \\
\hline
\end{tabular}

c

File 1). In general, there is a remarkable overlap between taxa found in the leaf and the carpological record (Table 3). Differences between the two records are mainly due to the lack of herbaceous species in the leaf fossil record. Of these, about 10 are strictly aquatic species, while most of the others can thrive in different habitats including wet meadows, riparian sites, forest undergrowth, etc. (Supplementary material File 1). One exception may be the genus Scleranthus, which is more common on dry sites and as pioneer in open places (Oberdorfer 1979).

In addition, a number of woody taxa are absent from the leaf record as well. These include Engelhardioideae,
Liriodendron, Corylopsis, Meliosma, Nyssa, Stuartia, Styrax and others (Supplementary material File 1) and the woody lianas Vitis (two species) and Parthenocissus. A few taxa (Populus, Quercus) are much more diverse in the leaf fossil record.

Modern distribution, vegetation signals and climatic ranges of relict taxa in the Pliocene flora of Frankfurt/M

Many elements in the flora of Frankfurt/M. have a relictual extant distribution range. Among the gymnosperms, Ginkgo, Calocedrus, Cryptomeria, Glyptostrobus, Sequoia, Taxodium, Sciadopitys, Cephalotaxus and 
Table 3 Comparison of carpofloras and leaf floras from the Pliocene of Frankfurt

\begin{tabular}{ll}
\hline Seeds and fruits recorded in Mädler (1939) \\
\hline $\begin{array}{l}\text { Gymnosperms } \\
25 \text { spp. }\end{array}$ \\
13 genera & 8 new species \\
Angiosperms & \\
78 spp. & 8 new species \\
50 genera & 19 also in leaf record \\
& 31 absent from leaf record \\
Of these: & 17 herbs or aquatic herbs \\
& 11 trees or shrubs \\
& 2 woody vines \\
& 1 fabaceous fruit
\end{tabular}

Torreya have highly relictual extant distributions either disjunct between North America and East Asia or confined to one of them (Table 1). The same is true for many angiosperm taxa such as Sassafras, Liquidambar, Cercidiphyllum, Eucommia and Trichosanthes.

Besides, several relict areas in western Eurasia harbour many of the plants recorded from Frankfurt. For example, in the Euxinian-Hyrcanian region (northern Turkey, Transcaucasia, to northern Iran), a great number of western Eurasian relict taxa are found (Buxus, Celtis, Gleditsia, Ilex, Parrotia, Pterocarya, Zelkova). Remarkably, all the genera reported from Frankfurt are growing in the Botanical Garden of Batumi (Georgia; Sharadze 1987). Trees such as Cryptomeria, Cunninghamia and Eucommia further have naturalised in the hinterland of Batumi (T. Denk, personal observation). A few relict species are confined to small areas in the East Mediterranean region (Liquidambar orientalis). Kvaček et al. (2008) noted that most plants from the late Pliocene flora of Auenheim (Alsace) belong to

Table 4 New species described in the Pliocene flora of Frankfurt

\begin{tabular}{ll}
\hline Mädler (1939) fruit and seed record & This study, leaf record \\
\hline Thuja pliocaenica & Magnolia waltheri \\
Potamogeton medicagoides & Pachysandra europaea \\
Carya longicarpa & Crataegus pentagynoides \\
Betula longisquamosa & Acer dombeyopsis \\
Corylopsis urselensis & Acer viburnoides \\
Eucommia europaea & Acer vitiforme \\
Prunus aviifolius & Eucommia szaferi \\
Acer palaeo-miyabei & Populus gregorii \\
& Populus canescentoides ${ }^{\text {a }}$ \\
& Quercus praecastaneifolia ${ }^{\text {a }}$
\end{tabular}

${ }^{a}$ Described from the late Pliocene flora of Willershausen mesophytic representatives of mixed coniferous and broad-leaved deciduous forests. The same is true for the Pliocene flora of Frankfurt. Overall, the Pliocene flora of Frankfurt can be viewed as an impoverished northern hemispheric Neogene forest flora with numerous exotic elements.

Palaeoenvironmental signals based on the IPR vegetation analysis (e.g. Kovar-Eder et al. 2008; Teodoridis et al. 2011) and CLAMP suggest a transitional vegetation (ecotone) between broad-leaved deciduous forest and mixed mesophytic forest thriving under the following (palaeo)climatic conditions, i.e. mean annual temperature (MAT), $10.6{ }^{\circ} \mathrm{C}$; warmest month mean temperature (WMMT), $22.3{ }^{\circ} \mathrm{C}$; coldest month mean temperature (CMMT), $-0.1{ }^{\circ} \mathrm{C}$; precipitation of the three wettest consecutive months (3-WET), $764.1 \mathrm{~mm}$; and 3-DRY, $166.8 \mathrm{~mm}$. The reconstructed climate parameters correspond to those of the coeval floras of Auenheim (Teodoridis et al. 2009) and Berga (Teodoridis and Kvaček 2015). The specific structure of the zonal woody key components of Frankfurt/M. i.e. broad-leaved deciduous (BLD)-75.7\%, broad-leaved evergreen (BLE)-15.6\%, sclerophyllous + legume-like (SCL + LEG)-9.1\%, dry herb (DRY HERB) - 4\% and mesophyllous herb (MESO HERB) $3.3 \%$, shows closest similarity based on the structure of zonal components to modern plant assemblages (mapping units) of "G56 - Balkanic-Rhodopean Oriental hornbeam-hophornbeam forests (Ostrya carpinifolia, Carpinus orientalis), partly with Haberlea rhodopensis" from Bulgaria and Greece and "F75 - Armorican (sessile oak-) beech forests (Fagus sylvatica, Quercus petraea) with Ilex aquifolium, Taxus baccata, Ruscus aculeatus, Blechnum spicant" from France and Great Britain (Bohn et al. 2004; see Supplementary material File 4). The climates under which these modern plant assemblages thrive are characterised by MAT 9 to $11^{\circ} \mathrm{C}$ and 10 to $12^{\circ} \mathrm{C}$, WMMT 18 to $22^{\circ} \mathrm{C}$ and 16 to $17^{\circ} \mathrm{C}$, CMMT - 2 to $0{ }^{\circ} \mathrm{C}$ and 4 to $7{ }^{\circ} \mathrm{C}$ and MAP $700 \mathrm{~mm}$ and 700 to $1000 \mathrm{~mm}$ (Bohn et al. 2004) and match those inferred for Frankfurt/M using CLAMP.

A survey of climatic parameters of conifer taxa that are today absent from western Eurasia but persisted in East Asia and/or North America shows that most of these genera tolerate fairly low mean temperatures of the coldest month (Table 2). A single monotypic genus, Glyptostrobus, is currently restricted to areas with coldest month mean temperatures close to the freezing point. However, observations and experiments on freezing tolerance of modern conifers suggest that the realised niches in relict conifers are reflecting only a very small part of their fundamental niches (Sakai 1971; Bannister and Neuner 2001). Assuming a modern distribution of rainfall and temperature over the year (rain maxima in summer, coldest in winter), the modern climate of Lugano in the south of Switzerland would provide conditions to accommodate the Pliocene flora of Frankfurt (Fig. 21 a, c). In contrast, several 
suitable climates in humid warm temperate regions of southwestern Europe and the eastern Black Sea region (Santander, Fig. 21b; San Sebastian, Batumi) have different rainfall and temperature patterns, with maximum rainfall in winter.

In a previous study, Thiel et al. (2012) used leaf physiognomic characteristics of dicotyledonous angiosperms (CLAMP, Spicer 2011-2019) to infer the palaeoclimate of Frankfurt. The reconstructed MAT $\left(12.2 \pm 1.2{ }^{\circ} \mathrm{C}\right)$, CMMT $\left(2.3 \pm 1.9^{\circ} \mathrm{C}\right)$ and MAP $(979-1333 \mathrm{~mm})$ closely match the conditions in sheltered areas south of the Alps (see above Lugano, Ljubljana, Udine; Lieth 1999). It is noteworthy that highly similar climate estimates are obtained from modern climate envelopes of North American and East Asian conifers (Table 2) and from leaf physiognomic signal of broad-leaved angiosperm leaves.

Speciation and extinction in the late Pliocene of Europe

Many cool temperate northern hemispheric tree genera that were abundant during the Pliocene went extinct in Europe or became restricted to small relict areas in western Eurasia during the Pleistocene (Svenning 2003; Magri et al. 2017). For example, Sciadopitys, Taxodioideae, Tsuga, Carya, Pterocarya and Zelkova persisted in northern Italy until less than one million years ago (Magri et al. 2017). The majority of taxa recorded for the Pliocene of Frankfurt persisted in western Eurasia until today (Table 1). According to Svenning (2003), increased cold and drought tolerance are important factors that determined whether tree taxa are still widespread in Europe, survived in relict areas or went extinct. Modern counterparts of extinct conifers in the Pliocene of Frankfurt are relatively cold tolerant (see above; Table 2) but are much more sensitive to cold than widespread modern cool temperate tree genera of Europe (cf. table 4 in Svenning 2003). Several new fossil species recognised in the present study and by Mädler (1939) are noteworthy, as they might reflect a Pliocene radiation that did not persist into modern times. Mädler (1939) established eight new species based on fruits and seeds (Table 3), while in the present study, seven new species were recognised (Table 4). Some of the taxa recognised as new species belong to genera that are still widespread in western Eurasia. For example, in the widespread northern hemispheric genus Acer, Acer dombeyopsis is morphologically closely similar to sections Pentaphylla and Lithocarpa, native to the Himalayas and East Asia. Acer viburnoides and vitiforme are extinct species in the Eurasian sect. Acer. Acer is still quite diverse in the flora of western Eurasia with ca. 17 species in three sections (van Gelderen et al. 1994; Grimm et al. 2007; Grimm and Denk 2014).

Likewise, the morphologically distinct Quercus praecastaneifolia strongly resembles a clade of East Asian white oaks (sect. Quercus) that is no longer represented in western Eurasia. It is interesting to note that leaf morphologies similar to extant East Asian species appeared in the Pliocene of Europe but did not persist into modern times. The late Pliocene Q. praecastaneifolia appears to belong to a clade of modern white oaks restricted to the Himalayas to East and Northeast Asia that are relatively frost resistant. In this case, lack of frost and drought tolerance alone are not sufficient to explain why this species went extinct in Europe (cf. Table 2 and table 4 in Svenning 2003). Similarly, Fagus in Frankfurt is virtually identical to modern East Asian species (F. hayatae subsp. pashanica, $F$. longipetiolata and F. crenata) and has not much in common with the modern western Eurasian Fagus populations. Accepting a late Pliocene (ca. 3.6-2-6 Ma) age for the Pliocene flora of Frankfurt, it is interesting to note that a recent study placed the time of divergence of regional populations of Fagus orientalis from the remainder of $F$. orientalis and $F$. sylvatica in the early Pleistocene (1.18-1.87 Ma). Fagus sylvatica s.str. diverged from the remainder of western Eurasian Fagus populations at ca. $817 \mathrm{ka}$ (Gömöry et al. 2018). This is in accordance with other studies (Fagus, Martinetto 2015; Quercus, Bagnoli et al. 2016; Abies, Piotti et al. 2017).

Acknowledgements Volker Wilde is thanked for facilitating the work in the collections of the Senckenberg Research Institute and Natural History Museum Frankfurt. We acknowledge the reviews by Lilla Hably and Dieter Uhl.

Funding information Open access funding provided by Swedish Museum of Natural History. The study was supported by projects PROGRES Q45 and Q17 carried out by the Charles University, Faculty of Science and Faculty of Education and by grant project GAČR (Czech Science Foundation) No 18-25057S. TD acknowledges the financial support by the Swedish Science Foundation (VR).

\section{Compliance with ethical standards}

Conflict of interest The authors declare that they have no competing interests.

Open Access This article is licensed under a Creative Commons Attribution 4.0 International License, which permits use, sharing, adaptation, distribution and reproduction in any medium or format, as long as you give appropriate credit to the original author(s) and the source, provide a link to the Creative Commons licence, and indicate if changes were made. The images or other third party material in this article are included in the article's Creative Commons licence, unless indicated otherwise in a credit line to the material. If material is not included in the article's Creative Commons licence and your intended use is not permitted by statutory regulation or exceeds the permitted use, you will need to obtain permission directly from the copyright holder. To view a copy of this licence, visit http://creativecommons.org/licenses/by/4.0/.

\section{References}

Andreánszky, G. (1959). Die Flora der Sarmatischen Stufe in Ungarn. Budapest: Akademiai Kiado.

APG IV. (2016). An update of the Angiosperm Phylogeny Group classification for orders and families of flowering plants: APG IV. Botanical Journal of the Linnean Society, 181, 1-20. 
Bagnoli, F., Tsuda, Y., Fineschi, S., Bruschi, P., Magri, D., Zhelev, P., Paule, L., Simeone, M. C., González-Martínez, S. C., \& Vendramin, G. G. (2016). Combining molecular and fossil data to infer demographic history of Quercus cerris: insights on European eastern glacial refugia. Journal of Biogeography, 43, 679-690.

Bannister, P., \& Neuner, G. (2001). Frost resistance and distribution of conifers. In F. J. Bigras \& S. J. Colombo (Eds.), Conifer cold hardiness (Vol. 1, pp. 3-21). Dordrecht: Kluwer.

Baranova, M. A. (1980). Sravnitel'no-stomatographicheskoe issledovanie semejst Buxaceae i Simmondsiaceae. In S. G. Zhilin (Ed.), Sistematika i evoljutsia vysshikh rastenii (pp. 68-75, 121). Leningrad: Nauka.

Barbour, M. G. (1988). California upland forests and woodlands. In M. G. Barbour \& W. D. Billings (Eds.), North American terrestrial vegetation (pp. 131-164). New York: Cambridge University Press.

Beerling, D. J., \& Royer, D. L. (2011). Convergent Cenozoic CO2 history. Nature Geoscience, 4, 418-420.

Bohn, U., Neuhäusl, R., Gollub, G., Hettwer, C., Neuhäuslová, Z., Raus, T., Schlüter, H., \& Weber, H. (2004). Map of the natural vegetation of Europe. Maßstab / Scale 1 : 2500 000. Münster: Landwirtschaftsverlag.

Boulay, J. N. (1890). Flore Pliocène des environs de Théziers (Gard.). Paris: Paul Klincksieck 70 p.

Boulter, M. C., \& Kvaček, Z. (1989). The Palaeocene flora of the Isle of Mull. Special Papers in Palaeontology, 42, 1-149.

Braun, A. (1845). Die Tertiär-Flora von Öhningen. Neues Jahrbuch für Mineralogie, Geologie und Paläontologie, 1, 164-173.

Braun, A. (1851).Verzeichnungen der fossilen Pflanzen von Oehningen. In E. Stizenberger (Ed.) Übersicht der Versteinerungen des Grossherzogthums Baden. Freiburg.

Brongniart, A. (1822). Sur la classification et la distribution des végétaux fossiles en general, et ceux des terrain de sediment supérieur en particulier. Mémoires du Muséum national d'histoire naturelle 8, 203-240.

Brown, R. W. (1935). Miocene leaves, fruits, and seeds from Idaho, Oregon, and Washington. Journal of Paleontology, 9(7), 572-587.

Buckland, W. (1836). Geology and mineralogy considered with reference to natural theology, I. London.

Bůžek, Č. (1971). Tertiary flora of the northern part of Pětipsy area (North-Bohemian Basin). Rozpravy Ústředního Ústavu Geologického, 36, 1-118.

Bůžek, Č., Kvaček, Z., \& Holý, F. (1985). Late Pliocene palaeoenvironment and correlation of the Vildštejn floristic complex within Central Europe. Rozpravy ČSAV, rada Matematika-přirodní Vědy, 95, 1-72.

Christensen, K. J. (1992). Revision of Crataegus sect. Crataegus and Notosect. Crataeguineae (Rosaceae - Maloideae) of the Old World. Systematic Botany Monographs, 35, 1-199.

Czeczott, H. (1951). Środkowo-mioceńska fora Zalesiec koło Wiśniowca I. Acta Geologica Polonica, 2, 349-445.

Denk, T. (1998). The beech (Fagus L.) in western Eurasia — an actualistic approach. Feddes Repertorium, 109, 435-463.

Denk, T. (2004). Revision of Fagus from the Tertiary of Europe and southwestern Asia and its phylogenetic implications. Documenta Naturae, 150, 1-72.

Denk, T., \& Grimm, G. W. (2005). Phylogeny and biogeography of Zelkova (Ulmaceae s.str.) as inferred from leaf morphology, ITS sequence data and the fossil record. Botanical Journal of the Linnean Society, 147, 129-157.

Denk, T., \& Velitzelos, D. (2002). First evidence of epidermal structures of Ginkgo from the Mediterranean Tertiary. Review of Palaeobotany and Palynology, 120, 1-15.

Denk, T., Grimm, G. W., \& Kvaček, Z. (2005). The Miocene floras of Iceland and their significance for late Cainozoic North Atlantic biogeography. Botanical Journal of the Linnean Society, 149(4), 369417.
Denk, T., Velitzelos, D., Güner, H. T., \& Ferrufino-Acosta, L. (2015). Smilax from the Miocene of the eastern Mediterranean with Caribbean biogeographic affinities. American Journal of Botany, $102,423-438$.

Denk, T., Grimm, G. W., Manos, P. S., Deng, M., \& Hipp, A. (2017). An updated infrageneric classification of the oaks: review of previous taxonomic schemes and synthesis of evolutionary patterns. In E. GilPeregrin, J. J. Peguero-Pina, \& D. Sancho-Knapik (Eds.), Oaks physiological ecology. Exploring the functional diversity of genus Quercus. Tree physiology 7 (pp. 13-38). Cham: Springer Nature.

Dorofeev, P. I. (1974). K istorii rody Glyptostrobus Engl. Botanicheskii Zhurnal, 59, 3-13.

Engelhardt, H., \& Kinkelin, F. (1908). Oberpliocäne Flora und Fauna des Untermaintales, insbesondere des Frankfurter Klärbeckens. Abhandlungen der Senckenbergischen Naturforschenden Gesellschaft, 29(3), 151-281.

Ettingshausen, C. v. (1851). Die Tertiaer-Floren der Oesterreichischen Monarchie. I. Fossile Flora von Wien. Abhandlungen der Kaiserlich-Königlichen Geologischen Reichsanstalt Wien, 1(1), $7-$ 36.

Ettingshausen, C. v. (1852). Fossile Pflanzenreste aus dem trachytischen Sandstein von Heiligenkreuz bei Kremnitz. Abhandlungen der Kaiserlich-Königlichen Geologischen Reichsanstalt, 1, 3. Abt.(5), $1-14$.

Ettingshausen, C. v. (1853). Beitrag zur Kenntniss der fossilen Flora von Tokay. Sitzungsberichte der Kaiserlichen Akademie der Wissenschaften, Mathematisch-Naturwissenschaftliche Classe, 11(4), 779-816.

Fang, J., Wang, Z., \& Tang, Z. (2011). Atlas of woody plants in China: distribution and climate. Beijing: Springer.

Ferguson, D. K. (1971). The Miocene flora of Kreuzau, western Germany. I. The leaf-remains. Verhandelingen, Afdeling Natuurkunde, Koninklijke Nederlands sksdémie Van Wetenschappen, Tweede Reeks, Deel, 60(1), 1-297.

Fischer, T. C., \& Butzmann, R. (2000). Die neogene Flora von Meleto (Valdarno, Italien) Paläobotanik, Paläoökologie und Paläoklima. Flora Tertiaria Mediterranea, 6, 1-187.

Florin, R. (1922a). Über das Vorkommen von Sciadopitys (Conif.) im deutschen Tertiär. Senckenbergiana, 4(1/2), 1-5.

Florin, R. (1922b). On the geological history of the Sciadopitineae. A preliminary note. Svensk Botanisk Tidskrift, 16, 260-270.

Gaudin, C. T., \& Strozzi, C. (1859). Contributions à la flore fossile italienne. II. Val d'Arno. Nouveaux Mémoires de la Société Helvétique des Sciences Naturelles, 17, 1-60.

Geissert, F. (1972). Neue Untersuchungen im Pliozän der Hagenauer Umgebung (Nördliches Elsass). Mainzer Naturwissenschaftliche Abhandlunge, 11, 191-221.

Geissert, F. (1973). Le pliocène et le quaternaire au nord de Strasbourg: note préliminaire sur la découvert de nauveaux végétaux pliocène à Auenheim (Bas-Rhin). Bulletin de l'Association Philomathique d'Alsace et de Lorraine, 15, 199-233.

Geissert, F., Gregor, H. J., \& Mai, H. D. (1990). Die "Saugbaggerflora", eine Frucht- und Samenflora aus dem Grenzbereich Miozän-Pliozän von Sessenheim im Elsass (Frankreich). Documenta Naturae, 57, 1208.

Geyler, T., \& Kinkelin, F. (1887). Oberpliocän-Flora aus den Baugruben des Klärbeckens bei Niederrad und der Schleuse bei Höchst a. M. Abhandlungen der Senckenbergischen Naturforschenden Gesellschaft, 15, 1-49.

Givulescu, R. (1973). Studii asupra unor epiderme fosile. Studii şi cerc. geol. geogr., s. geol., 18(2), 577-588.

Givulescu, R. (1975). Monographia holotyporum florae fossilis e Romania descriptorum (Monographie der aus Rumänien beschriebenen Holotypen fossiler Pflanzen). Mémoires Institut de Géologie et de Géophysique, 22, 1-72. 
Givulescu, R. (1990). Flora fosilăa miocenului superor de la Chiuzbaia. București: București Editura Academiei Române.

Givulescu, R., \& Olos, E. (1973). Paläobotanische Studien im Tertiär Siebenbürgens. Mémoires Institut de Géologie et de Géophysique, 19, 7-56.

Gömöry, D., Paule, L., \& Mačejovský, V. (2018). Phylogeny of beech in western Eurasia as inferred by approximate Bayesian computation. Acta Societatis Botanicorum Poloniae, 87(2), 3582. https://doi.org/ 10.5586/asbp.3582.

Göppert, H. R. (1855). Die tertiaere Flora von Schossnitz in Schlesien. Görlitz: Heynsche Buchhandlung (E. Remer.).

Gregor, H.-J., van der Burgh, J., Peters, A. M. M., \& Pingen, M. (2000). Torreya schulzii nov. spec. Samen einer exotischen Konifere aus dem NW-europäischen Pliozän (Hambach, Liessel). Documenta Naturae, 104(5), 1-31.

Grimm, G. W., \& Denk, T. (2014). The Colchic region as refuge for relict tree lineages: cryptic speciation in field maples. Turkish Journal of Botany, 38, 1050-1066.

Grimm, G. W., Denk, T., \& Hemleben, V. (2007). The evolutionary history and systematics of Acer section Acer-a case study of low-level phylogenetics. Plant Systematics and Evolution, 267, 215-253.

Grímsson, F., Denk, T., \& Símonarson, L. A. (2007). Middle Miocene floras of island - the early colonization of an island? Review of Palaeobotany and Palynology, 144, 181-219.

Guo, S.-X., \& Zhou, Z.-K. (1992). The megafossil legumes from China. In P. S. Herendeen \& D. L. Dilcher (Eds.), Advances in legume systematic, the fossil record (pp. 207-223). Kew: The Royal Botanical Gardens.

Hably, L., \& Kvaček, Z. (1997). Early Pliocene plant megafossils from the volcanic area in West Hungary. Studia Naturalia, 10, 5-151.

Hantke, R. (1954). Die fossile Flora der obermiozänen Oehninger Fundstelle Schrotzburg (Schienerberg, Süd-Baden). Denkschriften der Schweizerischen naturforschenden Gesellschaft, 80(2), 27-118.

Heer, O. (1859). Die tertiäre Flora der Schweiz, 3. Winterthur.

Hummel, A. (1983). The Pliocene leaf flora from Ruszów near Żary in Lower Silesia, SW Poland. Prace Museum Ziemi, 36, 9-104.

Hummel, A. (1991). The Pliocene leaf flora from Ruszów near Źary in Lower Silesia, South-West Poland, part II (Betulaceae). Acta Palaeobotanica, 31(1, 2), 73-151.

Iljinskaja, I. A. (1968). Neogenovye flora Zakarpatskoj oblasti USSR. Leningrad: Izdatelstvo Nauka, Leningradskoe otdelenie 114 pp.

Iljinskaya, I. A. (1982). Fagaceae. In A. Takhatajan (Ed.), Magnoliophyta fossilia URSS (Vol. 2, pp. 60-120). Saint Petersburg: Russian Academy of Sciences.

Iljinskaya, I. A. (1994). Juglans, vidy, ustanovlennye po list'jam i otpečatkam plodov. Magnoliophyta Fossilia URSS, 3, 69-77 Saint Petersburg, Russian Academy of Sciences.

Iljinskaya, I. A. (2005). Populus balsamoides Goepp. In L. Budantsev (Ed.), Magnoliophyta fossilia URSS (Vol. 4, pp. 109-112). Saint Petersburg: Russian Academy of Sciences.

Kemna, H. A., \& Westerhoff, W. E. (2007). Remarks on the palynologybased chronostratigraphical subdivision of Pliocene terrestrial deposits in NW-Europe. Quaternary International, 164/165, 184-196.

Kilpper, K. (1968). Koniferen aus den tertiären Deckschichten des niederrheinischen Hauptflözes 3. Taxodiaceae und Cupressaceae. Palaeontographica B, 124, 102-111.

Knobloch, E. (1964). Haben Cinnamomum scheuchzeri Heer und Cinnamomum polymorphum (Al. Braun) Heer nomenklatorisch richtige Namen? Neues Jahrbuch für Geologie und Paläontologie Monatshefte, 1964(10), 597-603.

Knobloch, E. (1988). Neue Ergebnisse zur Flora aus der Oberen Süsswassermolasse von Aubenham bei Ampfing (Krs. Mühldorf am Inn). Documenta Naturae, 42, 1-27.

Knobloch, E. (1998). Der pliozäne Laubwald von Willershausen am Harz. Documenta Naturae, 120, 1-302.
Knobloch, E., \& Kvaček, Z. (1976). Miozäne Blätterfloren vom Westrand der Böhmischen Masse. Rozpravy Ústředniho Ústavu Geologického, 42, 1-131.

Kolakovskij, A. A. (1952). The Pliocene flora of Sukhumi. Trudy Sukhumskogo Botanicheskogo Sada, 7, 83-130.

Kolakovskij, A. A. (1955). Pliocenovaja flora Meore-Atara. Trudy Sukhumskogo Botanicheskogo Sada, 8, 211-302.

Kolakovskij, A. A. (1958). Pervoe dopolnenie k Duabskoi pliotsenovoi flore. Trudy Sukhumskogo Botanicheskogo Sada, 11, 311-397.

Kolakovskij, A. A. (1964). The Pliocene flora of Kodor. Sukhumi Botanical Garden Monographs, 1, 1-200.

Kotlaba, F. (1963). Tertiary plants from three new localities in southern Slovakia. Acta Musei Nationalis Pragae, 19B, 53-72.

Kovar-Eder, J., \& Hably, L. (2006). The flora of Mataschen - a unique plant assemblage from the late Miocene of eastern Styria (Austria). Acta Palaeobotanica, 46(2), 157-233.

Kovar-Eder, J., \& Krainer, B. (1991). Flora und Sedimentologie der Fundstelle Reith bei Unterstorcha, Bezirk Feldbach in der Steiermark (Kirchberger Schotter, Pannonium C, Miozän). Jahrbuch der Geologischen Bundes-Anstalt, 134(4), 737-771.

Kovar-Eder, J., Jechorek, H., Kvaček, Z., \& Parashiv, V. (2008). The integrated plant record: an essential tool to reconstruct Neogene zonal vegetation in Europe. Palaios, 23, 97-111.

Kräusel, R. (1939). Zum Geleit. Abhandlungen der Senckenbergischen Naturforschenden Gesellschaft, 446, 2.

Kräusel, R. (1940). Die Frankfurter Wälder vor der Eiszeit. Natur und Volk, 70(9), 446-461.

Kräusel, R., \& Weyland, H. (1959). Kritische Untersuchungen zur Kutikularanalyse tertiärer Blätter IV. Dikotyledonen aus der Braunkohle. Palaeontographica B, 105(5-6), 101-124.

Krutzsch, W. (1966). Zur Kenntnis der präquartären periporaten Pollenformen. Geologie, 15(55), 16-71.

Kryshtofovich, A., \& Baikovskaja, T. (1965). Sarmatian flora of Krinka. Moscow: Nauka.

Kunzmann, L. (2014). On the fossil history of Pseudotsuga Carr. (Pinaceae) in Europe. Palaeobiodiversity and Palaeoenvironments, 94, 393-409.

Kunzmann, L., \& Mai, D. H. (2005). Die Koniferen der MastixioideenFlora von Wiesa bei Kamenz (Sachsen, Miozän) unter besonderer Berücksichtigung der Nadelblätter. Palaeontographica B, 272, 67135.

Kunzmann, L., Kvaček, Z., Mai, H. D., \& Walther, H. (2009). The genus Taxodium (Cupressaceae) in the Palaeogene and Neogene of Central Europe. Palaeogeography, Palaeoclimatology, Palaeoecology, 153, 153-183.

Kvaček, Z. (1976). Towards nomenclatural stability of European Tertiary conifers. Neues Jahrbuch für Geologie und Paläontologie Monatshefte, 1975(5), 284-300.

Kvaček, Z. (1979). Some members of Magnoliaceae from the European Tertiary. In Palaeontologická Konference 1977 (pp. 169-182). Prague: Charles University.

Kvaček, Z. (1984). Tertiary taxads of NW Bohemia. Acta Universitatis Carolinae, Geologica 1982, 4, 471-491.

Kvaček, Z. (2004). Revisions to the Early Oligocene flora of Flörsheim (Mainz Basin, Germany) based on epidermal anatomy. Senckenbergiana lethaea, 84, 1-73.

Kvaček, Z. (2008). Whole-plant reconstructions in fossil angiosperm research. International Journal of Plant Sciences, 169(7), 918-927.

Kvaček, Z., \& Konzalová, M. (1996). Emended characteristics of Cercidiphyllum crenatum (Unger) R. W. Brown based on reproductive structures and pollen in situ. Palaeontographica B, 239, 147155.

Kvaček, Z., \& Rember, W. C. (2000). Shared Miocene conifers of the Clarkia flora and Europe. Acta Universitatis Carolinae, Geologica, 44(1), 75-85. 
Kvaček, Z., \& Walther, H. (1991). Revision der mitteleuropäischen tertiären Fagaceen nach blattepidermalen Charakteristiken. IV. Teil. Fagus Linné. Feddes Repertorium, 102, 471-534.

Kvaček, Z., \& Wilde, V. (2010). Foliage and seeds of malvalean plants from the Eocene of Europe. Bulletin of Geosciences, 85(1), 163 182.

Kvaček, Z., Bůžek, Č., \& Holý, F. (1982). Review of Buxus fossils and a new large-leaved species from the Miocene of Central Europe. Review of Palaeobotany and Palynology, 37, 361-394.

Kvaček, Z., Velitzelos, D., \& Velitzelos, E. (2002). Late Miocene flora of Vegora Macedonia N. Greece. Athens: Korali.

Kvaček, Z., Dvořák, Z., Mach, K., \& Sakala, J. (2004). Třetihorni rostliny severočeské hnědouhelné pánve. Chomutov: Granit.

Kvaček, Z., Teodoridis, V., \& Gregor, H.-J. (2008). The Pliocene leaf flora of Auenheim, Northern Alsace (France). Documenta Naturae, 155(10), 1-108.

Kvaček, Z., Teodoridis, V., \& Wang, Q. (2009). Ilex geissertii sp. n. (Aquifoliaceae), a fossil ancestor of Ilex sect. Ilex in the upper Miocene and Pliocene of Europe. Review of Palaeobotany and Palynology, 157, 192-210.

Kvaček, Z., Teodoridis, V., \& Roiron, P. (2011). A forgotten Miocene mastixioid flora of Arjuzanx (Landes, SW France). Palaeontographica B, 285, 3-111.

Kvaček, Z., Teodoridis, V., Mazouch, P., \& Roiron, P. (2014a). Fossil seed cones of Pinus L. (sect. Pinus, subsect. Pinaster Loudon, Sula group) from the late Neogene and early Pleistocene of Europe. Palaeontographica B, 291, 1-24.

Kvaček, Z., Lieven, U., \& Gregor, H.-J. (2014b). Pinus timleri - ein wichtiges Element aus der pliozänen Flora des Tagebaues Hambach (RWE Power AG). Documenta Naturae, 195, 23-47.

Latham, R. E., \& Ricklefs, R. E. (1993). Continental comparisons of temperate-zone tree species diversity. In R. E. Ricklefs \& D. Schluter (Eds.), Species diversity in ecological communities: historical and geographical perspectives (pp. 294-314). Chicago: University of Chicago Press.

Laurent, L. (1904). Flore pliocène des cinerites du Pas-de-la-Moungudo et de Saint-Vincent-la-Sabie avec une introduction géologique et paléontologique par P. Marty. Annales de Musée d'Histoire Naturélle Marseille Géologie, 9, 1-313.

Laurent, L., \& Marty, P. (1923). Flore foliaire pliocéne des argiles de Reuver et des gisements synchroniques voisins (Limbourg Hollandais). Mededelser Rijks Geologische Dienst, B, 1, 1-180.

Lieth, H. (1999). Climate diagram world atlas on CD. Leiden: Backhuys.

Macovei, G. (2013). A revision of Taxaceae remains of the Late Miocene fossil flora from Chiuzbaia, Maramures County, Romania. Carpathian Journal of Earth and Environmental Sciences, 8, 245 248.

Mädler, K. (1939). Die pliozäne Flora von Frankfurt am Main. Abhandlungen der Senckenbergischen Naturforschenden Gesellschaft, 446, 1-202.

Magri, D., Di Rita, F., Aranbarri, J., Fletcher, W., \& Gonzalez-Samperiz, P. (2017). Quaternary disappearance of tree taxa from Southern Europe: timing and trends. Quaternary Science Reviews, 163, 2355.

Mai, D. H. (1975). Beiträge zur Bestimmung und Nomenklatur fossiler Magnolien. Feddes Repertorium, 86(9-10), 559-578.

Mai, D. H. (1986). Über Typen und Originale tertiärer Arten von Pinus L. (Pinaceae) in mitteleuropäischen Sammlungen. Ein Beitrag zur Geschichte der Gattung in Europa. Feddes Repertorium, 97(9-10), 571-605.

Mai, D. H. (1995). Tertiäre Vegetationsgeschichte Europas. Jena: Gustav Fischer Verlag.

Mai, D. H., \& Walther, H. (1985). Die obereozänen Floren des Weisselster-Beckens und seiner Randgebiete. Abhandlungen des Staatlichen Museums für Mineralogie und Geologie zu Dresden, $33,1-260$.
Mai, D. H., \& Walther, H. (1988). Die pliozäne Flora von Thüringen, Deutsche Demokratische Republik. Quartärpaläontologie, 7, 55297.

Mantzouka, D., Sakala, J., Kvaček, Z., Koskeridou, E., \& Ioakeim, C. (2019). Two fossil conifer species from Alonissos Island (Iliodroma, Greece). Geodiversitas, 41(3), 125-142. https://doi.org/10.5252/ geodiversitas2019v41a3http://geodiversitas.com/41/3.

Martinetto, E. (2001). The role of central Italy as a centre of refuge for thermophilous plants in the late Cenozoic. Acta Palaeobotanica, 41, 299-319.

Martinetto, E. (2015). Monographing the Pliocene and early Pleistocene carpofloras of Italy: methodological challenges and current progress. Palaeontographica B, 293, 57-99.

Martinetto, E., Scardia, G., \& Varrone, D. (2007). Magnetostraigraphy of the Sturia di Lanzo fossil forest succession (Piedmont, Italy). Rivista Italiana di Paleontologia e Stratigrafia, 113(1), 109-125.

Martini, E., Radtke, G., \& Schiller, W. (2011). Hanauer Becken. In Deutsche Stratigraphische Kommission (Ed.), Stratigraphie von Deutschland IX. Tertiär, Teil 1 (Vol. 75, pp. 225-262). Heft: Schriftenreihe der Deutschen Gesellschaft für Geowissenschaften Hannover.

Massalongo, A., \& Scarabelli, G. (1859). Studii sulla flora fossile e geologia stratigrafica del Senigaliese. Imola.

McIntyre, D. (1991). Pollen and spore flora of an Eocene forest, eastern Axel Heiberg Island, NWT. In R. L. Christie \& N. J. McMillan (Eds.), Tertiary fossil forests of the Geodetic Hill, Axel Heiberg Island (pp. 83-97). Ottawa Geological Survey.

Meyer, H. W., \& Manchester, S. R. (1997). The Oligocene Bridge Creek Flora of the John Day Formation, Oregon. University of California. Publications in Geological Science, 141, 1-195.

Mohr, B. (1986). Die Mikroflora der oberpliozänen Tone von Willershausen (Kreis Northeim, Niedersachsen). Palaeontographica B, 198(3-6), 133-156.

Němejc, F. (1975). Paleobotanika, vol. 4. Praha: Nakladatelství Československé Akademie Věd.

Oberdorfer, E. (1979). Pflanzensoziologische Exkursionsflora. Stuttgart: Verlag Eugen Ulmer.

Palamarev, E., \& Kitanov, G. (1977). The genus Acer L. in Pliocene flora of the Gotze Delchev district. Fitologiya, 8, 3-18 in Bulgarian.

Palamarev, E., \& Kitanov, G. (1988). Fossil macroflora of the Beli brjag coal-basin. In V. Velchev (Ed.), 100th anniversary of academician N. A. Stojanov (pp. 183-206). Sofia: Bulgarian Academy of Sciences (in Bulgarian).

Palamarev, E., Bozukov, V., Uzunova, K., Petkova, A., \& Kitanov, G. (2005). Catalogue of the Cenozoic plants of Bulgaria (Eocene to Pliocene). Phytologia balcanica, 11(3), 215-364.

Piotti, A., Leonarduzzi, C., Postolache, D., Bagnoli, F., Spanu, I., Brousseau, L., Urbinati, C., Leonardi, S., \& Vendramin, G. G. (2017). Unexpected scenarios from Mediterranean refugial areas: disentangling complex demographic dynamics along the Apennine distribution of silver fir. Journal of Biogeography, 44, 1547-1558.

Pop, E. (1936). Flora Pliocenică dela Borsec. Cluj-Napoca. Universitatea Regele Ferdinand i Cluj, Facultatea de Științe.

Procházka, M., \& Bůžek, C. (1975). Maple leaves from Tertiary of North Bohemia. Rozpravy Ústředniho Ústavu Geologického, 41, 1-86.

Rasche, L., \& Kovar-Eder, J. (2009). Woody angiosperm taxa of the Canarian laurel forests: leaf morphology and cuticular structures. Stuttgarter Beiträge zur Naturkunde A, Neue Serie, 2, 447-494.

Ravelo, A. C., Andreasen, D. H., Lyle, M., Lyle, A. O., \& Wara, M. W. (2004). Regional climate shifts caused by gradual global cooling in the Pliocene epoch. Nature, 429, 263-267.

Rehder, A. (1915). Synopsis of the Chinese species of Pyrus. Proceedings of the American Academy of Arts and Science, 50, 225-241.

Reid, C., \& Reid, E. M. (1915). The Pliocene flora of the Dutch-Prussian border. Mededelingen Rijksopsporing Delfstoffen, 6, 1-178. 
Rérolle, L. (1884-85). Etudes sur les végétaux fossiles de Cerdagne. Revue des Sciences Naturelles Montpellier, 3(4), 1-92.

Retallack, G. J. (2001). A 300-million year record of atmospheric carbon dioxide from fossil plant cuticles. Nature, 411, 287-290.

Rüffle, L. (1963). Die obermiozänen (sarmatische) Flora vom Randecker Maar. Paläontologische Abhandlungen, 1(3), 139-298.

Sakai, A. (1971). Freezing resistance of relicts from the Arcto-Tertiary flora. New Phytologist, 70, 1199-1205.

Saporta, G., \& Marion, A. F. (1876). Recherches sur les végétaux fossils de Meximieux. Archives de Musée d'Histoire Naturelle, 1, 131-335.

Schaarschmidt, F. (1980). Wald und Klima am Main in Wandel der Zeiten. Der Palmengarten, 180, 12-16.

Schneider, W. (2004). Eine blätterführende Taphocoenose im 2. Miozänen Flöz von Nochten (Lausitz): Taxonomie, Taphonomie und Phytostratigraphie. Palaeontographica B, 268(1-3), 1-74.

Sharadze, N. N. (Ed.). (1987). Derevia i kustarniki Batumskogo botanicheskogo sada: annotirovannii spisok [Trees and shrubs of the Batumi Botanical Garden: an annotated list]. Tbilisi: Metsniereba in Russian.

Shi, G., Zhou, Z., \& Xie, Z. (2010). A new Cephalotaxus and associated epiphyllous fungi from the Oligocene of Guangxi, South China. Review of Palaeobotany and Palynology, 161, 179-195.

Smiley, C. J., \& Rember, W. C. (1985). Composition of the Miocene Clarkia flora. In C. J. Smiley (Ed.), Late Cenozoic history of the Pacific Northwest (pp. 95-112). San Francisco: Pacific Division, American Association for the Advancement of Science.

Smith, R. F. (1967). The leaf dimorphism of Liquidambar styraciflua L. American Midland Naturalist, 77(1), 42-50.

Spicer, R.A. (2011-2019). CLAMP website: http://clamp.ibcas.ac.cn/ (checked January 2019).

Spicer, R. A., Valdes, P. J., Spicer, T. E. V., Craggs, H. J., Srivastava, G., Mehrotra, R. C., \& Yang, J. (2009). New development is CLAMP: calibration using global gridded meteorological data. Palaeo-geography, Palaeoclimatology, Palaeoecology, 283, 91-98.

Stefanoff, B., \& Jordanoff, D. (1934). Weitere Materialien zur Kenntnis der fossilen Flora des Pliozän bei dem Dorf Kurilo (Bez. Sofia). Université de Sofia. Faculté Agronomique. Annuaire, 2, 1-55 (in Bulgarian).

Stojanoff, N., \& Stefanoff, B. (1929). Beitrag zur Kenntnis der Pliozänflora der Ebene von Sofia. Zeitschrift der Bulgarischen Geologischen Gesellschaft, 1(3), 4-120.

Straus, A. (1930). Dicotyle Pflanzenreste aus dem Oberpliozän von Willershausen I. Jahbuch des Preussischen Geologischen Landesamtes, 51(1), 302-336.

Straus, A. (1952). Beiträge zur Pliocänflora von Willershausen III. Die niederen Pflanzengruppen bis zu den Gymnospermen. Palaeontographica B, 83(1-3), 1-44.

Straus, A. (1992). Die oberpliozäne Flora von Willershausen am Harz. Berichte der Naturhistorischen Gesellschaft Hannover, 134, 7-115.

Ströbitzer-Hermann, M., \& Kovar-Eder, J. (2003). Acer L.: some stratigraphically relevant species and their importance as potenital indicators of vegetation conditions. Acta Universitatis Carolinae, Geologica, 46, 101-106.

Stuchlik, L., Ziembińska-Tworzydło, M., Kohlman-Adamska, A., Grabowska, I., Słodkowska, B., Worobiec, E., \& Durska, E. (2014). Atlas of the pollen and spores of the Polish Neogene. Volume 4-Angiosperms (2). Kraków: Polish Academy of Sciences.

Stur, D. (1867). Beiträge zur Kenntnis der Flora der Süsswasserquarze, der Congerien- und Cerithienschichten im Wiener und ungarischen Becken. Magyar Állami Földtani Intézet Évkönyv, 17(1), 77-188.

Svenning, J.-C. (2003). Deterministic Plio-Pleistocene extinctions in the European cool-temperate tree flora. Ecology Letters, 6, 646-653.

Sveshnikova, I. (1953). Nakhodka roda Cryptomeria Don v meoticheskikh otlozheniakh Gruzii. Doklady AN SSSR, Nov. Ser., 92(2), 417-419.
Sveshnikova, I. (1963). Opredelitel sovremennykh i iskopaemykh predstavetelej Sciadopityaceae i Taxodiaceae po epiderme listjev. Botanicheskij institut im. V.L. Komarova akademii nauk SSSR, Trudy, ser. 8. Paleobotanika, 4, 205-229.

Szafer, W. (1947). The Pliocene flora of Kros'cienka in Poland. II. Descriptive part. Kraków: Polskiej Akademii Umiejętności.

Szafer, W. (1954). Pliocene flora from the vicinity of Czorsztyn (West Carpathians) and its relationship to the Pleistocene. Warszawa: Wydawnictwa Geologiczne.

Szafer, W. (1961). Mioceńska flora ze Starych Gliwic na Ślansku (Miocene flora from Stare Gliwice in upper Silesia). Institut Geologiczny Prace, 33, 1-205.

Takhtajan, A. (1982). Magnoliophyta fossilia URSS. Vol. 2, Ulmaceae Betulaceae. Leningrad: Nauka 216 p.

Tanai, T. (1983). Revisions of Tertiary Acer from East Asia. Journal of the Faculty of Sciences, Hokkaido University IV, Geology and Mineralogy, 20, 291-390.

Tanai, T., \& Suzuki, N. (1965). Late Tertiary floras from northeastern Hokkaido, Japan. Palaeontological Society of Japan, Special Paper, 10, 1-117.

Teodoridis, V., \& Kvaček, Z. (2015). Palaeoenvironmental evaluation of Cainozoic plant assemblages from the Bohemian Massif (Czech Republic) and adjacent Germany. Bulletin of Geosciences, 90(3), 695-720.

Teodoridis, V., Kvaček, Z., \& Uhl, D. (2009). Pliocene palaeoenvironment and correlation of the Sessenheim-Auenheim floral complex. Palaeodiversity, 2, 1-17.

Teodoridis, V., Kovar-Eder, J., \& Mazouch, P. (2011). Integrated plant record (IPR) vegetation analysis applied to modern vegetation in southeastern China and Japan. Palaios, 26, 623-638.

Teodoridis, V., Kvaček, Z., Hua, Z., \& Mazouch, P. (2012). Environmental analysis of the mid-latitudinal European Eocene sites of plant macrofossils and their possible analogues in East Asia. Palaeogeography, Palaeoclimatology, Palaeoecology, 333334(2012), 40-58.

Teodoridis, V., Bruch, A. A., Martinetto, E., Vassio, E., Kvaček, Z., \& Stuchlik, L. (2017). Plio-Pleistocene floras of the Vildštejn Formation in the Cheb Basin, Czech Republic - a review and a new paleoenvironmental evaluation. Palae-ogeography, Palaeoclimatology, Palaeoecology, 467(2017), 166-190.

Thiel, C., Klotz, S., \& Uhl, D. (2012). Palaeoclimate estimates for selected leaf floras from the late Pliocene (Reuverian) of Central Europe based on different palaeobotanical techniques. Turkish Journal of Earth Sciences, 21, 263-287.

Thompson, R. S., Anderson, K. H., \& Bartlein, P. J. (1999a). Atlas of relations between climatic parameters and distribution of important trees and shrubs in North America-hardwoods. U.S. Geological Survey Professional Paper, 1650-B, 1-423.

Thompson, R. S., Anderson, K. H., \& Bartlein, P. J. (1999b). Atlas of relations between climatic parameters and distributions of important trees and shrubs in North America - introduction and conifers. U.S. Geological Survey Professional Paper, 1650-A, 1-269.

Thompson, R. S., Anderson, K. H., \& Bartlein, P. J. (2000). Atlas of relations between climatic parameters and distributions of important trees and shrubs in North America — additional conifers, hardwoods, and monocots. U.S. Geological Survey Professional Paper, 1650-C, $1-386$.

Unger, F. (1841-1847). Chloris protogaea. Beiträge zur Flora der Vorwelt. Leipzig: Engelmann.

Unger, F. (1850). Genera et species plantarum fossilium. Wien: Braunmüller.

Uzunova, K., \& Palamarev, E. (1993). An investigation of the leaf epidermis of the European (non-Balkan) species of the genus Quercus. Fitologia, 45, 3-15.

Van der Burgh, J. (2001). Leaves and cuticles from the upper part of the Rhenish browncoal. Documenta Naturae, 138, 25-47. 
Van Gelderen, D. M., de Jong, P. C., \& Oterdoom, H. J. (1994). Maples of the World. Portland: Timber Press $458 \mathrm{p}$.

Viviani, V. (1833). Sur les restes de plantes fossiles trouvés dans les gypses tertiaires de Stradella près de Pavie. Mémoires de la Société Géologique de France, 1(1), 129-134.

Walther, H. (1972). Studien über tertiäre Acer Mitteleuropas. Abhandlungen des Staatlichen Museums für Mineralogie und Geologie Dresden, 19, 1-309.

Walther, H. (2003). Magnolien in den paläogenen Blattfloren Mitteleuropas. Courier Forschungsinstitut Senckenberg, 241, 131145.

Walther, H., \& Kvaček, Z. (2007). Early Oligocene flora of Seifhennersdorf (Saxony). Acta Musei Nationalis Pragae, Series B - Historia Naturalis, 63(2-4), 85-174.

Walther, H., \& Zastawniak, E. (1991). Fagaceae from Sośnica and Malczyce (near Wrocław, Poland). A revision of original materials by Göppert 1852 and 1855 and a study of new collections. Acta Palaeobotanica, 31(1,2), 153-199.

Walther, H., \& Zastawniak, E. (2005). Sapindaceae (Aceroideae) from the late Miocene flora of Sośnica near Wroclaw-a revision of Göppert's original materials and a study of more recent collections. Acta Palaeobotanica, 45(1), 85-106.

Weber, C. A. (1898). Über eine omorikaartige Fichte aus einer dem älteren Quartär Sachsens nagehörendem Moorbildung. Engler's Botanischen Jahrbücher, 23, 510-540.

Weyland, H., Kilpper, K., \& Berendt, W. (1967). Kritische Untersuchungen zur Kutikularanalyse tertiärer Blätter VII. Nachträge $\mathrm{zu}$ früheren Arbeiten über Epidermen aus der niederrheinischen Braunkohle und neue Arten. Palaeonto-graphica, $B, 120,151-168$

Wolfe, J. A., \& Spicer, R. A. (1999). Fossil leaf character states: multivariate analysis. In T. P. Jones \& N. P. Rowe (Eds.), Fossil plants and spores: modern techniques (pp. 233-239). London: Geological Society.

Wolfe, J. A., \& Tanai, T. (1987). Systematics, phylogeny, and distribution of Acer in the Cenozoic of western North America. Journal of the Faculty of Sciences, Hokkaido University IV, Geology and Mineralogy, 22, 1-246.

Worobiec, G., \& Szynkiewicz, A. (2016). Neogene wetland vegetation based on a leaf assemblage from the Bełchatów Lignite Mine (Central Poland). Acta Palaeobotanica, 56(2), 441-497.

Wu, Z., \& Raven, P. (2008). Flora of China, vol. 11. Oxalidaceae through Aceraceae. Saint Louis: Missouri Botanical Garden Press.

Yang, J., Spicer, R. A., Spicer, T. E. V., \& Li, C. S. (2011). 'CLAMP online': a new web-based palaeoclimate tool and its application to the terrestrial Paleogene and Neogene of North America. Palaeobiodiversity and Palaeoenvironments, 91, 163-183.

Zachos, J., Pagani, M., Sloan, L., Thomas, E., \& Billups, K. (2001). Trends, rhythms, and aberrations in global climate 65 Ma to present. Science, 292(5517), 686-693.

Zagwijn, W. H. (1960). Aspects of the Pliocene and Early Pleistocene vegetation in the Netherlands. Mededelingen Geologische Stichting C-III, 1(5), 1-78.

Zastawniak, E., \& Walther, H. (1998). Betulaceae from Sośnica near Wrocław (Poland) - a revision of Goeppert's original materials and study of more recent collections. Acta Palaeobotanica, 38(1), 87-145.

Zhilin, S. G. (1974). Tretichnye flory Ustjurta. Leningrad: Nauka.

Publisher's note Springer Nature remains neutral with regard to jurisdictional claims in published maps and institutional affiliations. 